Claremont Colleges

Scholarship@ Claremont

CGU Theses \& Dissertations

CGU Student Scholarship

2013

\title{
Vaudeville, Popular Entertainment and Cultural \\ Division in the Inland Empire, 1880-1914
}

Mark Hauser

Claremont Graduate University

\section{Recommended Citation}

Hauser, Mark. (2013). Vaudeville, Popular Entertainment and Cultural Division in the Inland Empire, 1880-1914. CGU Theses \& Dissertations, 78. http://scholarship.claremont.edu/cgu_etd/78. doi: 10.5642/cguetd/78

This Open Access Master's Thesis is brought to you for free and open access by the CGU Student Scholarship at Scholarship @ Claremont. It has been accepted for inclusion in CGU Theses \& Dissertations by an authorized administrator of Scholarship @ Claremont. For more information, please contact scholarship@cuc.claremont.edu. 
Vaudeville, Popular Entertainment and Cultural Division in the Inland Empire, 1880-1914

\author{
by \\ Mark Hauser \\ Claremont Graduate University \\ Spring 2013
}

(C) Copyright Mark Hauser, 2013

All rights reserved. 


\section{APPROVAL OF THE REVIEW COMMITTEE}

This thesis has been duly read, reviewed, and critiqued by the Committee listed below, which hereby approves the manuscript of Mark Hauser as fulfilling the scope and quality requirements for meriting the degree of Master of Arts in History.

Janet Farrell Brodie Claremont Graduate University

Professor of History

Robert Dawidoff Claremont Graduate University

Professor of History 


\section{Table of Contents}

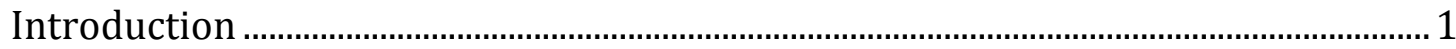

Chapter 1 - Urban Social Change and Vaudeville ........................................................... 6

Chapter 2 - Nineteenth-Century American Popular Entertainment............................2 29

Chapter 3 - Vaudeville in the Inland Empire...................................................................52

Appendix A - Opera House Performances ………………………………………………...... 71

Appendix B - Vaudeville Performances ............................................................................97

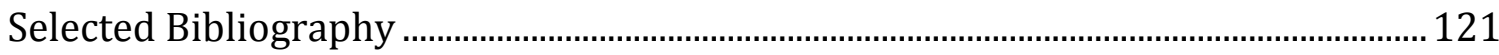




\section{Introduction}

"Some day, I'm afraid, the eggheads will take [Red Skelton] up and start reading social significance into his antics. Let's hope they don't because this has ruined many a good performer." - Groucho Marx ${ }^{1}$

American vaudeville emerged from the saloons that dotted the Bowery neighborhood of New York City during the 1880s. Over the course of the next 50 years vaudeville became the most popular entertainment in the country, resonating with a changing nation in a way that few other entertainment options were capable of doing. Audiences spread across the country in far-flung, rural areas were treated to the same performers as their big-city brethren, thanks to cross-country theater chains that spanned the nation. Even after the decline of vaudeville in the 1920s its aesthetic continued to shape American popular culture for decades thanks to radio, film and television's reliance on comedians, singers and dancers who had honed their skills in front of vaudeville audiences.

Over the past 70 years performers and critics have written memoirs and books that help document the history of American vaudeville. This paper will draw on these popular sources written to document an art form that fell from its commanding height atop popular culture to explain the intricacies and excitement of American vaudeville. A few scholars have provided additional commentary, reflecting on the significance of vaudeville within the context of American social transformation of the late nineteenth and early twentieth centuries. Albert McLean's 1965 book American Vaudeville as Ritual represented one of the first attempts at creating a scholarly history of vaudeville, exploring the links between

\footnotetext{
${ }^{1}$ Groucho Marx, Groucho and Me (New York: Da Capo Press, Paperback Edition, 1995), 137.
} 
vaudeville, urbanization and what he terms the "Myth of Success" that vaudeville promoted for urban audiences. Parker Zellers's 1971 biography of Tony Pastor is full of details on the earliest days of vaudeville and Pastor's efforts to differentiate his vaudeville shows from other variety shows during the 1880 s, and also makes efforts to improve upon Gilbert's history of vaudeville. These early works placed vaudeville within the context of middle class stability and comfort.

Robert Snyder's The Voice of the City focused on the role of vaudeville as a unifying force in New York City during the early twentieth century that appealed across class and ethnic backgrounds, broadening the study of vaudeville beyond the middle class. Camille Forbes's recent biography Introducing Bert Williams provided important details on one of the most successful entertainers of the first two decades of the twentieth century and on African-American performers in vaudeville. Lawrence Levine's important Highbrow/Lowbrow will help frame discussions of cultural hierarchy and evolving understandings of high and low culture within American society during the early twentieth century. Alison Kibler's 1999 book Rank Ladies explored similar themes by documenting the important role of female performers and audience played in accepting and rejecting theater owners' attempts to solidify cultural hierarchies. This paper will also draw heavily on past scholarship of popular entertainments of the nineteenth century to help demonstrate vaudeville's distinct appeal to large numbers of Americans in a way that other forms of entertainment were unable to do.

Virtually all prior scholarship on vaudeville has focused on major markets such as New York City, the bustling east coast hub of American cultural life during 
the era of vaudeville's emergence. However, this paper will attempt to move beyond these narrow confines to explore vaudeville's role in small town communities by examining an area east of Los Angeles known colloquially as the "Inland Empire." Communities such as San Bernardino, Riverside and Redlands that lie in the Inland Empire were coming into their own during the 1880s and experienced massive growth during the early twentieth century, presenting an interesting contrast with more established urban areas so often studied by scholars of vaudeville. By focusing on this region, it becomes possible to examine the relationship between vaudeville and the millions of Americans who did not live in the major urban areas previously covered by scholarship on vaudeville.

In order to capture the Inland Empire's relationship with vaudeville and popular entertainment, I collected sources from a variety of libraries and special collections around the region. I had initially hope to focus my studies on performers and their acts, hoping that I could analyze newspaper reviews and photographs to demonstrate the types of identity formation vaudeville was promoting. However, I found that most local archives did not have very detailed records on vaudeville theaters, nor did they have much in the way of photographic evidence, and the few newspaper articles were often promotions of performers coming to town in upcoming weeks rather than actual reviews of what had been on display. As a result, I revised my research to focus on the broad changes taking place within popular entertainment as a response to the formation of urban communities. I reviewed microfilm rolls of the San Bernardino Daily Sun at the library of California State University San Bernardino, and requested microfilm rolls of many other 
newspapers from the California library system. The California Room at the Norman Feldheym Library in San Bernardino provided background information on popular entertainment in San Bernardino, particularly its files and press clippings on the San Bernardino Opera House. The Loring Opera House and Theatre Program Collection at the Riverside Public Library provided access to theatrical programs, while the library offered online access to newspapers such as the Riverside Enterprise and Riverside Daily Press. The Heritage Room of the A.K. Smiley Public Library in Redlands also provided useful information regarding the Wyatt Opera House in Redlands, and a few copies of The Citrograph newspaper. All of these sources were used to help shape an understanding of popular culture in the community, and to generate the original tables I present in Chapters Two and Three.

This paper's structure reflects my desire to engage with scholarship on social change in early twentieth century America. Chapter One will focus specifically on the emergence of vaudeville as popular entertainment, the urban social changes that helped make it particularly relevant, and the growth of the Inland Empire. Chapter Two will examine the other entertainment options of the nineteenth century America and why they were unable to match the appeal of vaudeville, as well as their place within the popular culture of the Inland Empire. Chapter Three will focus specifically on the place of vaudeville within the Inland Empire. Two appendices at the conclusion of the paper will outline all of the documented performances that occurred at Opera Houses and vaudeville theaters in the Inland Empire. All of this information will provide a detailed overview of vaudeville in the 
Inland Empire, and vaudeville's place in American society of the early twentieth century undergoing rapid social change that reshaped cultural hierarchies. 


\section{Chapter 1 \\ Urban Social Change and Vaudeville}

The late nineteenth and early twentieth centuries were an era of remarkable change in the United States, made more prominent by the country's increasing urbanization. Since the end of the Civil War Americans had begun to encounter rising income inequality that was only exacerbated as the decades passed. Immigrants from countries outside of the traditional western European homelands of the early nineteenth century began arriving in waves, and African Americans newly freed from the bonds of slavery were able to move across the country. Women began to demand a greater role in civic society, leading social reform efforts and demanding rights equal to those of male citizens.

All of these new currents in American life demanded a revolution in the way the country perceived itself and the values this society promoted. These values needed to reflect those of an increasingly diverse, urban population that was constantly moving and evolving. About sixty miles east of Los Angeles, several communities founded during the late nineteenth century grew rapidly and in many ways embodied these traits. This area, consisting of San Bernardino County, the largest county in the United States, and Riverside County, a smaller breakaway county, constitute what is known locally as "the Inland Empire." The largest cities in the area, San Bernardino and Riverside, gave these counties their name, and together with Redlands, another notable city in San Bernardino County, they constitute an important case study of small, emerging cities that are often overlooked by scholars fixated on the communities that grew to dominate California such as Los Angeles and San Francisco. By studying these developing communities 
it is possible to examine both how successful these urban values were in penetrating small communities across the United States and the converse - ways in which urban values did not fully apply to growing communities and therefore only became common once communities had grown into more diverse, metropolitan areas.

As American political society and culture underwent profound changes, this ongoing shift naturally encouraged a revolution in popular entertainment. During the early twentieth century vaudeville emerged as America's favorite entertainment precisely because it matched urban society's values. It offered a variety of rapidly changing entertainments that matched the variety found in urban life. Vaudeville also benefited from producers who bowed to social standards of respectability that broadened its appeal across all classes. Additionally, producers were able to take advantage of emerging transportation and promotional networks to forge national theater chains, encouraging circuits that brought vaudeville into towns across the country. Because vaudeville drew heavily on urban life, social respectability and new technologies, a study of American vaudeville from its birth in 1880 until 1914 is tightly intertwined with an examination of emerging class, racial and social distinctions that were in flux during this period.

\section{Vaudeville and Urban America}

Vaudeville matched the lifestyle and values of urban Americans more than any other form of entertainment of the day, a major factor in why it was able to become the dominant amusement of the era. ${ }^{2}$ It emerged out of variety

\footnotetext{
${ }^{2}$ Chapter Two will examine other forms of entertainment that were popular during this era and note the specific reasons why they were unable to keep pace with the shifts in American values during the late nineteenth and early twentieth centuries.
} 
performances that had been an important staple of American popular culture for decades. Since the 1820 s opera had incorporated variety performers during the interludes between acts, a practice that was very popular with audiences. ${ }^{3}$ By the mid-nineteenth century minstrelsy had also developed a reliance on rotating performers specializing in a variety of acts including singing, dancing and comedy, returning to the background after their few moments in the spotlight. This constant rotation had a particular appeal to audiences who were used to the quick pace and rapid changes of urban life. ${ }^{4}$

American variety theater owner M.B. Leavit claimed to have coined the term "vaudeville" in 1880 as a combination of the French words "vaux de ville" meaning "worthy of the city's patronage," linking this particular form of variety entertainment with a perception of social values. ${ }^{5}$ However, the man responsible for integrating variety entertainment with nineteenth-century urban American values was Tony Pastor. A theater owner and producer in the rough and tumble Bowery neighborhood of New York, Pastor had entered theater management because his Catholic faith encouraged him to eliminate what he considered to be objectionable content. ${ }^{6}$ Before Pastor opened his $14^{\text {th }}$ Street Theatre in 1881, Bowery theaters catered to the local working class and were first and foremost

\footnotetext{
${ }^{3}$ Karel Ahlquist, Democracy at the Opera: Music, Theater, and Culture in New York City, 1815-60 (Urbana, IL: University of Illinois Press, 1997), 2-3.

${ }^{4}$ Gunther Barth, City People: The Rise of the Modern City Culture in Nineteenth-Century America (New York: Oxford University Press, 1980), 201-202, 204.

${ }^{5}$ Albert F. McLean, American Vaudeville as Ritual (Lexington, KY: University of Kentucky Press, 1965), 19.

${ }^{6}$ Parker Zellers, Tony Pastor: Dean of the Vaudeville Stage (Ypsilanti, MI: Eastern Michigan University Press, 1971), 41.
} 
saloons, with prostitutes freely working amongst the crowd. ${ }^{7}$ Pastor noted that these conditions were unappealing to the growing population of middle class urban women who wanted to share in the entertainments of the city, and by "cleaning up" variety entertainment he could offer these women access to performers they wanted to see. ${ }^{8}$ Throughout the 1870 s, Pastor's theaters began to challenge the variety establishment by eliminating objectionable material from performers' acts in an effort to attract women and families from the middle and respectable working classes. His earliest theaters still offered alcohol, but in separate areas outside of the main auditorium; by the time he opened the $14^{\text {th }}$ Street Theatre he had eliminated its sale entirely and relied solely on ticket sales to generate his profits. ${ }^{9}$ Pastor's successful efforts to make variety entertainment respectable and broaden its appeal are generally cited as the birth of vaudeville in the early 1880s. B.F. Keith and his partner Edward Albee came to dominate vaudeville entertainment across the United States in the early twentieth century through their circuit of theaters that continued this focus on respectability. The duo received financing for their first vaudeville theater from the Catholic Diocese of Boston, promising the elimination of vulgarity and profanity from shows, with acts judged and censured by Sunday school teachers who vigilantly stood watch at the back of the theater during performances. ${ }^{10}$

Pastor's new standards were restrictive, and were both a response to the audience's demand for decency as well as the promotion of certain social ideals held

\footnotetext{
${ }^{7}$ Zellers, Tony Pastor, xv.

${ }^{8}$ Barth, City People, 195.

9 Zellers, Tony Pastor, 54-55, 72.

${ }^{10}$ Joe Laurie, Vaudeville: From the Honky-Tonks to the Palace (New York: Holt, 1953), 338-339.
} 
by theater managers and producers. In the words of historian John Dimeglio, "Vaudeville, for better or worse, directed morals and attitudes...While it reflected mass attitudes, it also exercised a considerable power in shaping its viewers' feelings...If it is considered that [vaudeville] audiences contained great numbers of young minds easily influenced by amusements, it is no wonder that the influence of vaudeville on America is still great."11 Twenty-first century observers of the material performed by vaudeville comedians operating under these decency standards may note that it appears hackneyed or simplistically slapstick. However, within the confines of nineteenth and early twentieth century American society their acts actually represented more language play than the sexually suggestive content performed by circus and burlesque comics of the era. ${ }^{12}$ Other performers found ways to perform risqué material by manipulating popular perceptions of beauty and sexuality. Throughout her career famed vaudeville singer Sophie Tucker used sexually provocative songs in her act, yet because of her heavyset and unattractive appearance she was not interpreted as an object of sexual desire and did not run afoul of censors. ${ }^{13}$ Tucker herself noted several factors that allowed her to seemingly flout contemporary standards:

“Often I am asked: 'Why do you sing hot songs?' And I can answer truthfully: 'I've never sung a single song in my whole life on purpose to shock anyone. I sing to entertain. My 'hot numbers' (and especially the songs Jack Yellen has been writing for me the past twenty years) are all, if you will notice, written around something that is real in the lives of millions of people. They are songs that mean something to everybody who hears them.'...Another thing

\footnotetext{
${ }^{11}$ John E. DiMeglio, Vaudeville U.S.A. (Bowling Green, OH: Bowling Green University Popular Press, 1973), 197.

12 McLean, American Vaudeville as Ritual, 119.

${ }_{13}$ Robert C. Allen, Horrible Prettiness: Burlesque and American Culture (Chapel Hill, NC: University of North Carolina Press, 1991), 272.
} 
about my 'hot numbers,' they are all moral. They have to do with sex, but not with vice. That, I believe, is one secret of their unfailing popularity with American audiences. The other secret that makes for their success is the fact that they are all written in the first person. When I'm singing them I am talking about myself. This makes me do them better than I could do a song about some indefinite third person. And the audience likes them better that way....the audience found my distress funny."14

These new performance standards helped vaudeville attract its initial audience of middle class Americans in droves. Vaudeville appealed to the middle class of white-collar workers who appreciated the onstage rituals of abundance and vitality, and had reevaluated and rejected older family values and traditions. ${ }^{15}$ Vaudeville performances depicted and celebrated a mythic view of American life that embraced glamour and glibness as important to success, in contrast to rural Americans who saw pious morality as a central component. ${ }^{16}$ Vaudeville offered audiences a compromise that if upon emigrating to a city, one was willing to suspend the belief that Christian life demanded the renunciation of pleasure, theater owners such as Pastor and Keith would eliminate other objections such as offensive language and vice. ${ }^{17}$ Keith hung a sign in his vaudeville houses, outlining exactly what he expected from his performers, stating:

"You are hereby warned that your act must be free from all vulgarity and suggestiveness in words, action, and costume while playing in any of Mr. Keith's houses, and all vulgar, double-meaning and profane words and songs must be cut out of your act before the first performance. If you are in doubt as to what is right or wrong, submit it to the resident manager at rehearsal. Such words as liar, slob, son-of-a-gun, devil, sucker, damn and all other words unfit for the ears of ladies and children, also any reference to

\footnotetext{
${ }^{14}$ Sophie Tucker, Some of These Days: The Autobiography of Sophie Tucker (Garden City, NY: Doubleday, Doran and Company, Inc., 1945), 95-96.

${ }^{15}$ McLean, American Vaudeville as Ritual, 41-43.

16 McLean, American Vaudeville as Ritual, 9-10.

17 McLean, American Vaudeville as Ritual, 72.
} 
questionable streets, resorts, localities, and bar-rooms are prohibited under fine of instant discharge." 18

In the eyes of historian Albert McLean, performance standards therefore became an example of class identification rather than genuine religious fervor, writing:

"For the vaudeville audiences themselves, the appeal to purity and uplift was more a snobbish identification with upper-middle class taste than it was a matter of religious conviction. The managers, in adopting the sanctimonious tone, claimed that they were out for the 'carriage trade,' but the claim itself was addressed to the aspirant members of the new class of white collar workers. For this group, cut off by levels of education and income from the enjoyment of great and expensive art, the appeal to the sensibilities was vaguely desirable, but provided no firm explanation for their leisure activities. What they needed was a justification for fun, a frame of reference which they might not fully comprehend, but which would, at least, provide a basis for distinguishing between vaudeville and grand opera on the one hand, and vaudeville and a revival meeting on the other."19

These values helped transform vaudeville into an almost exclusively middle-class entertainment following the depression of 1893, the year F.F. Proctor introduced his "continuous vaudeville" model. ${ }^{20}$ Continuous vaudeville offered ongoing performances throughout the day, and was marketed by the phrase, "After breakfast go to Proctor's, after Proctor's go to bed," an advance that shaped vaudeville into its famous, final form with a master of ceremonies introducing an ever changing array of acts. ${ }^{21}$ The success of vaudeville led to the creation of mammoth theaters such as the Palace Theatre in New York that stood as monuments to wealth, power and prestige, playing to the audience's desire for success. ${ }^{22}$

\footnotetext{
${ }^{18}$ Robert W. Snyder, The Voice of the City: Vaudeville and Popular Culture in New York (New York: Oxford University Press, 1989), 29 quoting Edwin Milton Royle, "The Vaudeville Theatre," Scribner's 26 (October 1899): 487.

${ }^{19}$ McLean, American Vaudeville as Ritual, 82.

${ }^{20}$ Allen, Horrible Prettiness, 250.

${ }^{21}$ Russell Sanjek, American Popular Music and Its Business: The First Four Hundred Years (New York: Oxford University Press, 1988), 338.

22 McLean, American Vaudeville as Ritual, 208. Barth, City People, 216.
} 
Vaudeville performances also demonstrated currents that were shared by more than just the middle class, encompassing the urban lifestyle of millions of Americans. Variety performances identified urban problems and suggested ways of coping with them, with efficiency and discipline the key to both a successful performance onstage and a successful life in the city. ${ }^{23}$ Vaudeville humor, which often boiled down to laughing at others and their suffering rather than with them, suggested a difficulty in finding intimacy with the numerous strangers one encountered in daily city life, while also providing a feeling of superiority. ${ }^{24}$ Yet comedy was not just slapstick, but regularly observed, "the inefficiency of government and the paradoxes facing an unsophisticated immigrant populace," which, "provided an outlet for their audiences when they supplied laughs on subjects which were sensitive and unsolvable."25 Songs such as "Give My Regards to Broadway," "Hello Central, Give Me Heaven," and "The Man Who Broke the Bank in Monte Carlo," through their titles alone spoke to the joy and loneliness of urban life, glorifying success and teaching urban etiquette. ${ }^{26}$ Magicians and spiritualists occasionally presented themselves as mysterious masters of the occult, but performers such as Houdini urged audiences instead to look beyond these homespun traditions, fostering the primacy of science over spiritualism. ${ }^{27}$ Even animal acts demonstrated a fault line in the struggle between Darwinian

\footnotetext{
23 Barth, City People, 225.

${ }^{24}$ Barth, City People, 217.

25 John Lahr, Notes on a Cowardly Lion: The Biography of Bert Lahr (New York: Knopf, 1969), 29, quoted in DiMeglio, Vaudeville U.S.A., 42. DiMeglio, Vaudeville U.S.A., 42-43.

${ }^{26}$ Barth, City People, 219.

27 McLean, American Vaudeville as Ritual, 163. John F. Kasson, Houdini, Tarzan, and the Perfect Man:

The White Male Body and the Challenge of Modernity in America (New York: Hill and Wang, 2001, 143.
} 
evolutionists and sentimentality. ${ }^{28}$ In short, virtually every act on the vaudeville stage directly or indirectly was influenced by modern, urban American life and the problems it posed.

Vaudeville also appealed to respectable working class and immigrant Americans by playing an active role in overcoming urban isolation and loneliness and serving as an important tool of Americanization. Vaudeville performances enabled immigrants to the United States and migrants from rural America to come in contact with, and learn the values of, the urban civilization absorbing them. ${ }^{29}$ After learning rudimentary English, immigrants increasingly were drawn to vaudeville theaters outside of their local ethnic community. In these theaters, patrons were required to applaud at appropriate moments and maintain respectable silence during the performance. By patronizing vaudeville theaters immigrant newcomers could learn and embrace the values of middle-class America, leaving behind the working-class norms accepted in local ethnic theaters. ${ }^{30}$ Vaudeville performers often came from lower class, immigrant backgrounds very similar to their audiences and crafted acts that referenced these experiences. ${ }^{31}$ At the same time, many immigrant groups began to assimilate into American life during the 1890s and 1900s, and stereotypical portrayals of comic Irish and Jewish Americans onstage no longer resonated with audiences as strongly as they

\footnotetext{
${ }^{28}$ McLean, American Vaudeville as Ritual, 147.

${ }^{29}$ McLean, American Vaudeville as Ritual, 11. Abel Green, Show Biz, From Vaude to Video (New York: Holt, 1951), 9.

30 Barth, City People, 214-215.

31 DiMeglio, Vaudeville U.S.A., 59.
} 
previously had, though they were still common. ${ }^{32}$ Even African Americans, who had been depicted since the minstrel era as unfit, quasi-savages and were generally unwelcome in first-class vaudeville theaters, began to challenge the popular biases against them on stage. ${ }^{33}$ By the 1900s, "black and tan" establishments in New York that catered to an audience of black men and white women constituted the low end of vaudeville, and offered an opening for talented African American performers such as Bert Williams and George Walker. ${ }^{34}$ By the 1910s, Williams had become one of the most famous entertainers in America, and challenged popular perceptions since, in the words of critic Edith Isaacs, "somehow or other, laughing at Bert Williams came to be tied up in people's minds with liberalism, charity and the Thirteenth Amendment." 35 Vaudeville emerged as the dominant urban entertainment of early twentieth century America by embracing middle class social values that new members of the urban working class were encouraged to adopt.

\section{Social Change, 1880-1914}

Historians have previously outlined a number of changes in American society that occurred during the late nineteenth and early twentieth centuries. During this time class divisions began to widen and grow more pronounced, which resulted in competing aims for upper, middle and lower class citizens. The rapid pace at which industrialization unfolded during the 1880s began to alienate

\footnotetext{
32 Alicia Kae Koger, "A Critical Analysis of Edward Harrigan's Comedy" (Ph.D. diss., University of Michigan, 1984), 309. M. Alison Kibler, Rank Ladies: Gender and Cultural Hierarchy in American Vaudeville (Chapel Hill, NC: University of North Carolina Press, 1999), 56.

${ }^{33}$ Camille F. Forbes, Introducing Bert Williams: Burnt Cork, Broadway, and the Story of America's First Black Star (New York: Basic Civitas, 2008), 46, 56. Kibler, Rank Ladies, 134.

${ }^{34}$ Forbes, Introducing Bert Williams, 72-73.

35 Edith J.R. Isaacs, The Negro in the American Theatre (New York: Theatre Arts, Inc., 1947), 41, quoted in DiMeglio, Vaudeville U.S.A., 115.
} 
working class wage earners who sought to preserve a sense of decency and honor in their work. In some communities this goal was respected, but many found that as society focused increasingly on financial success, old customs, traditions and morality dissolved. ${ }^{36}$ In areas where business elites were absent or had a singular focus on economic exploitation, laborers were seen as a dangerous revolutionary class and marginalized, which in turn encouraged workers to attack their oppressors. ${ }^{37}$ The massive inequality between workers and owners was roundly perceived as unjust and undermined traditional beliefs that business success was somehow the result of moral virtue on the part of a company's owner. ${ }^{38}$ Workers took increasing pride in their output and thought of themselves as honorable producers, contrasting their labor with that of lawyers, bankers and brokers got rich by manipulating others' money. ${ }^{39}$ Belief in a traditional understanding of the Protestant ethic that held a man's character to be responsible for his economic success was no longer possible following the depression of 1893 when it became clear that many workers were poor through no fault of their own. ${ }^{40}$

The growing need for collective action in the face of inequality helped spur the growth of national labor unions during the 1880s and 1890s as communities turned to national leaders to help overcome local jurisdictional problems that prevented their successful mobilization. ${ }^{41}$ Unions in urban areas played a crucial role in shaping individual identity, as the influx of inexperienced workers to cities

36 Jackson Lears, Rebirth of a Nation: The Making of Modern America, 1877-1920 (New York: HarperCollins, 2009), 55.

37 Robert H. Wiebe, The Search for Order, 1877-1920 (New York: Hill and Wang, 1967), 47.

38 Lears, Rebirth of a Nation, 52. Wiebe, The Search for Order, 133-134.

${ }^{39}$ Lears, Rebirth of a Nation, 74.

40 Lears, Rebirth of a Nation, 173.

41 Wiebe, The Search for Order, 124. 
required not only jobs and housing, but also a sense of belonging, which unions provided in loyalty towards an occupation, rather than political parties or ethnic groups. ${ }^{42}$ While workers and their unions demonstrated pride in the fruits of their labor, factory managers fought against them and pushed for more efficient production. These managers introduced automated machinery that removed skilled workers from their payrolls and simultaneously sped up the pace of their remaining workers' lives. ${ }^{43}$

The individual identity a worker could find in a union was essential during the late nineteenth century, when the nature of an individual's life was constantly in flux. As more miles of train tracks were laid, workers became increasingly mobile and moved often to find better employment and wages, often with the seasons, perhaps constructing railways in the west during the spring and traveling to work in Chicago during the winter. ${ }^{44}$ In this world of uncertainty, the definition of race took on increasing importance, and led to increasing focus on the racial categorization of immigrants, who were feared as a source of poverty, crime, political corruption and social subversion. ${ }^{45}$ By the early 1900s, immigration had been termed a "problem" with illiteracy seen as a major contributing factor, leading to increased calls for immigrant restriction and expanded Americanization programs. ${ }^{46}$

In addition to the escalating strife between upper and lower classes, urban America was also home to a growing middle class of professionals such as doctors,

\footnotetext{
42 Wiebe, The Search for Order, 12, 129.

${ }^{43}$ Lears, Rebirth of a Nation, 82-83.

${ }^{44}$ Lears, Rebirth of a Nation, 75-76.

45 Lears, Rebirth of a Nation, 93, 95. Wiebe, The Search for Order, 54.

46 Wiebe, The Search for Order, 210.
} 
lawyers, economists and social workers, as well as an increasing number of specialists in fields such as business, labor and agriculture. ${ }^{47}$ The growth of this professional class coincided with the development of new methods of measuring achievement. Numbers and statistics became central to measuring success, making greatness synonymous with mass quantity and demonstrating the superiority of American industrial output and by extension the American way of life. ${ }^{48}$ Due to their experiences as overseers and middle managers, business professionals adopted a worldview that demanded a need for constant interaction and adjustment to increase social performance. ${ }^{49}$ This resulted in the aforementioned push towards efficiency of time and effort. ${ }^{50}$ However, the relative success of this professional class also made them more inclined to revise their stance on certain values such as thriftiness, as they made money they were willing to spend on consumer goods as a way to demonstrate personal wealth and status. ${ }^{51}$ This consumerism was not just an urban trend, but one that spread quickly throughout the rural United States, making thriftiness a virtue held by the working classes that needed to generate more value from their pay. ${ }^{52}$

In some areas of the rural West and South, social upheavals spawned the birth of "Populism," with the Populist Party formed in $1891 .{ }^{53}$ Populist reformers challenged the growth of monopoly capitalism by calling for the restraint of

\footnotetext{
47 Wiebe, The Search for Order, 112.

48 Wiebe, The Search for Order, 40.

${ }^{49}$ Wiebe, The Search for Order, 146.

50 Wiebe, The Search for Order, 155.

${ }^{51}$ Lears, Rebirth of a Nation, 56.

${ }^{52}$ Lears, Rebirth of a Nation, 148-149, 78.

${ }^{53}$ Lears, Rebirth of a Nation, 164.
} 
corporate power through antitrust laws and the adoption of direct elections. ${ }^{54}$ However, Populism never was able to develop a strong foothold in urban areas because its platform did not mesh with the needs of the urban workforce. Populists demanded the free coining of silver that meant little to urban workers and called for the elimination of tariffs that protected corporations employing urban workers. The political rallies of William Jennings Bryan, the charismatic face of Populism, were also off-putting as they often resembled rural camp meetings. ${ }^{55}$ Following Bryan's failed Presidential campaign in 1896, Populism began to slowly die away as a major political movement. ${ }^{56}$

In urban areas at the dawn of the twentieth century monopoly capitalism was attacked by a band of reformers who viewed the world not through the lens of the factory, but instead as a process of historical progress and evolution. Their views became known as "Progressivism," and emanated from influential citizens who felt that appreciating modernization was central to their personal interests. ${ }^{57}$ Progressivism focused on cleaning society of corruption, leading efforts to reform medical laws and the Prohibition movement, which had also been supported by rural Populists. ${ }^{58}$ The Progressive movement was independent of the working class Socialist movement that had grown out of the nineteenth-century organized labor

\footnotetext{
${ }^{54}$ Wiebe, The Search for Order, 180.

${ }^{55}$ Lears, Rebirth of a Nation, 189.

${ }^{56}$ Wiebe, The Search for Order, 105.

57 Wiebe, The Search for Order, 177.

${ }^{58}$ Lears, Rebirth of a Nation, 195, 200.
} 
movement to continue campaigns for an eight-hour workday and increased workers' rights, though it did advocate on behalf of many of these same issues. ${ }^{59}$

Economic and political factors were joined by cultural shifts that helped shape the competing identities varying groups of Americans adopted or found forced upon them. While in many instances culture served as a barrier to varying social groups or classes, the great diversity of urban life demanded that something be able to transcend these differences. As historian Gunther Barth noted in City People, his study of American urban culture during the early twentieth century, urban life offered a chance for citizens to share feelings about common life and recognize mutual concerns, forming the basis for a shared urban culture. ${ }^{60}$ The pace of urbanization had increased during the late nineteenth century when monopolistic corporations grew and centralized their operations, concentrating wealth in urban areas. ${ }^{61}$ Cities such as Chicago teemed with energy and vitality, and had a natural appeal to youth. ${ }^{62}$ By early twentieth century, cities also offered services such as the streetcars and gas and electric lamps championed by Progressives that quickened the pace of life and prolonged days. ${ }^{63}$

A key component of urban culture was popular entertainment, which in the late nineteenth and early twentieth centuries was available on a wider scale than ever before due to shifts in American leisure habits and technological advancement. Freed from a rural life whose schedule was dictated by the agricultural duties

\footnotetext{
59 Daniel T. Rodgers, Atlantic Crossings: Social Politics in a Progressive Age (Cambridge, MA: Belknap Press of Harvard University Press, 1998), 58.

${ }^{60}$ Barth, City People, 23.

${ }^{61}$ Lears, Rebirth of a Nation, 89.

${ }^{62}$ Lears, Rebirth of a Nation, 141.

63 Rodgers, Atlantic Crossings, 144.
} 
associated with the changing seasons, urban workers were able to craft a new, informal lifestyle. Traditional holiday celebrations remained, but their formality declined, and workers were also able to claim control over their workweek free time. ${ }^{64}$ As a result, leisure activities became a marketplace capable of being dominated by big business ventures, and producers in the nascent mass entertainment field quickly capitalized. ${ }^{65}$

By the 1890s, growth in the railroad industry allowed performers to travel quickly across the country from town to town. Shrewd theatrical producers now had the ability to develop a nationwide network of theaters, and encouraged performers to travel on a circuit that connected these theaters, creating a unified, national popular culture. Theater owners also drew upon a growing culture of advertising, which allowed lithographs and broadsheets to be posted cheaply and quickly and often focused primarily on promoting theatrical productions. ${ }^{66}$ These promotional tools helped stir demand for a national popular culture, a demand that proved so great even smaller communities lacking access to the drawing power of a major theater could still hope to attract imitators of well-promoted star performers. Thrifty theater owners who noted that such imitators would work for a lower price than genuine headliners enthusiastically embraced this practice. ${ }^{67}$ These nationwide theater circuits formed the organizational basis of vaudeville, the most popular entertainment of the early twentieth century.

\footnotetext{
64 Barth, City People, 19.

${ }^{65}$ Roy Rosenzweig, Eight Hours for What We Will: Workers and Leisure in an Industrial City, 18701920 (New York: Cambridge University Press, 1983), 172.

${ }^{66}$ Armond Fields, Lillian Russell: A Biography of "America's Beauty" (Jefferson, NC: McFarland, 1999), 57-58.

67 Green, Show Biz, 43. Laurie, Vaudeville, 248-249.
} 


\section{Development of the Inland Empire, 1880-1914}

Southern Calfornia's Inland Empire of the late nineteenth century was not a densely populated region, although it was growing rapidly. During the middle of the century the area had begun a brief period of expansion after 500 Mormons settled in San Bernardino in 1851, drawn by the ease at which the surrounding plains could be irrigated. However, a few years after the city of San Bernardino was incorporated in 1854, Brigham Young recalled the community back to Utah, which brought a period of stagnation to the region. ${ }^{68}$ By the 1870 s, the area had again begun to grow after the discovery of gold in the hills surrounding San Bernardino and orange groves took root in Riverside, located about fifteen miles south. ${ }^{69}$ The emerging gold and orange industries were important to the initial expansion of the region, and the arrival of railways in the late 1870s rapidly accelerated this growth. A dispute with regional rail power Southern Pacific slowed the San Bernardino's incorporation onto rail networks until 1876, when it was connected with San Francisco and Los Angeles. Southern Pacific's monopoly on the region's railways was broken by the California Southern, which constructed a competing terminal in 1883. The Santa Fe Railway soon purchased California Southern and integrated into their nationwide network, allowing orange growers to travel east, market their goods and further expand their operations in the region. ${ }^{70}$ Home to two competing terminals, railway fares into San Bernardino plummeted, bringing new immigrants to the city and

\footnotetext{
${ }^{68}$ Doyce B. Nunis, Jr., Southern California Local History: A Gathering of the Writings of W.W. Robinson (Los Angeles: Historical Society of Southern California, 1993), 384-386, 388-389.

${ }^{69}$ Nunis, Southern California Local History, 393, 400. Walter C. Schuilling, San Bernardino County, Land of Contrasts (Woodland Hills, CA: Windsor Publications, 1984), 66.

${ }^{70}$ Schuilling, San Bernardino County, 62, 65-66.
} 
driving a real estate boom during the late 1880s. Naturally, this real estate boom led to the expansion of a lumber industry in the surrounding forests, which encouraged further exploration of the region. ${ }^{71}$ By the 1890s, major silver, gold and borax mines had opened across San Bernardino County, bringing floods of new jobs and immigrants to its cities and surrounding areas. ${ }^{72}$ Table 1.1 outlines the rapid growth of San Bernardino, Riverside and their surrounding areas.

\begin{tabular}{|c|c|c|c|c|c|}
\hline \multicolumn{7}{|c|}{ Table 1.1 - County Population, $1880-1920^{73}$} \\
\hline County & 1880 & 1890 & 1900 & 1910 & 1920 \\
\hline $\begin{array}{c}\text { San } \\
\text { Bernardino }\end{array}$ & 7,786 & 25,497 & 27,929 & 56,706 & 73,401 \\
\hline Riverside & - & - & 17,897 & 34,696 & 50,297 \\
\hline
\end{tabular}

As more people moved to the region, individual cities began to take on different standings within the local community. As the home of a large population of railway workers, San Bernardino developed a reputation as a working class town, from which other cities attempted to distance themselves. Riverside sought a middle class identity and waged a campaign to break from San Bernardino and form its own county. This dynamic is the focus of an 1887 editorial in the San Bernardino Daily Courier, the city's Democratic-leaning newspaper, which attacked previous articles in the San Bernardino Times and Riverside Press about a perceived drinking problem in San Bernardino. There, next to ads for Brocker \& Reinhold imported

\footnotetext{
${ }^{71}$ Nunis, Southern California Local History, 408. Schuilling, San Bernardino County, 93.

${ }^{72}$ Schuilling, San Bernardino County, 95-96.

${ }^{73}$ U.S. Census of Population and Housing, 1880: Volume I, Statistics of the Population of the United States (Washington, DC: Government Printing Office, 1882), 51. U.S. Census of Population and Housing, 1890: Volume I, Report on the Population of the United States (Washington, DC: Government Printing Office, 1895), 11. U.S. Census of Population and Housing, 1900: Volume I, Population of States and Territories (Washington, DC: Government Printing Office, 1901), 11. U.S. Census of Population and Housing, 1910: Volume II, Population Reports by State Alabama-Montana (Washington, DC: Government Printing Office, 1913), 148. U.S. Census of Population and Housing, 1920: Volume III, Composition and Characteristics of the Population by States (Washington, DC: Government Printing Office, 1922), 115.
} 
carpets and H.J. Weil \& Co.'s fine wines and cigars, the editors of the Daily Courier

observed:

"There is something of a difference between a large and growing city like San Bernardino, with the heavy force of railroad men, laborers and a large floating population, and a relatively isolated rural village like Riverside...San Bernardino, aside from its extraneous population, is as sober a town as shy in the State to-day...That San Bernardino is wicked, Riverside has been proclaiming since there was a Riverside. Perhaps this is the reason why they want a division of the county. They are afraid of contamination with the ungodly, roistering people north of the Santa Ana, these beatified bucolics. Some time ago we expressed a hope that the Riverside sneers at San Bernardino would cease. That hope, we fear, will never be realized."74

As Table 1.2 illustrates, the great irony of the article is that while San Bernardino County may have had a larger population, the city of Riverside actually had a slightly larger population than the city of San Bernardino and would remain so for decades.

\begin{tabular}{|c|c|c|c|c|}
\hline \multicolumn{5}{|c|}{ Table $1.2-$ City Population, $1890-1920^{75}$} \\
\hline City & 1890 & 1900 & 1910 & 1920 \\
\hline $\begin{array}{c}\text { San } \\
\text { Bernardino }\end{array}$ & 4,012 & 6,150 & 12,779 & 18,721 \\
\hline Redlands & 1,904 & 4,797 & 10,449 & - \\
\hline Riverside & 4,683 & 7,973 & 15,212 & 19,341 \\
\hline
\end{tabular}

Yet the population of these cities was still relatively close, and other information from the census reveals these cities and their surrounding communities were demographically very similar. Tables $1.3,1.4$ and 1.5 outline the sex, ethnicity and literacy rates for both San Bernardino and Riverside counties.

\footnotetext{
74 “Bucolic Bigotry," San Bernardino Daily Courier, 23 September 1887.

${ }^{75}$ Urban population for these communities was not recorded by the 1880 census, nor was it recorded for Redlands by the 1920 census. U.S. Census of Population and Housing, 1910, 148. U.S. Census of Population and Housing, 1920, 115.
} 


\begin{tabular}{|c|c|c|c|c|c|c|}
\hline \multicolumn{8}{|c|}{ Table 1.3 - County Population by Sex, 1880-192076 } \\
\hline County & 1880 & 1890 & 1900 & 1910 & 1920 \\
\hline San & Male & 4,352 & 14,666 & 15,333 & 31,535 & 38,435 \\
\hline Bernardino & Female & 3,434 & 10,831 & 12,596 & 25,171 & 34,956 \\
\hline Riverside & Male & - & - & 9,601 & 19,089 & 26,676 \\
\cline { 2 - 7 } & Female & - & - & 8,296 & 15,607 & 23,621 \\
\hline & & - & &
\end{tabular}

\begin{tabular}{|c|c|c|c|c|c|c|}
\hline \multicolumn{7}{|c|}{ Table 1.4 - County Population by Ethnicity, $1880-1920^{77}$} \\
\hline & County & 1880 & 1890 & 1900 & 1910 & 1920 \\
\hline \multirow{6}{*}{$\begin{array}{c}\text { San } \\
\text { Bernardino }\end{array}$} & White (Native) & 6,988 & 24,101 & 26,605 & 43,472 & 56,906 \\
\hline & White (Foreign) & - & - & - & 10,681 & 14,183 \\
\hline & "Colored"/"Negro" & 17 & 313 & 216 & 642 & 608 \\
\hline & Chinese & 123 & 682 & 388 & - & 107 \\
\hline & Japanese & - & 2 & 148 & - & 533 \\
\hline & "Indian" & 658 & 399 & 572 & - & 1,029 \\
\hline \multirow[t]{6}{*}{ Riverside } & White (Native) & - & - & 16,421 & 26,385 & 38,120 \\
\hline & White (Foreign) & - & - & - & 5,228 & 8,544 \\
\hline & "Colored"/"Negro" & - & - & 254 & 518 & 885 \\
\hline & Chinese & - & - & 316 & - & 103 \\
\hline & Japanese & - & - & 97 & - & 626 \\
\hline & "Indian" & - & - & 809 & - & 1,958 \\
\hline
\end{tabular}

\begin{tabular}{|c|c|c|c|}
\hline Table 1.5 -Illiteracy Rates of Voting Age Males, $1900-1920^{78}$ \\
\hline County & 1900 & 1910 & 1920 \\
\hline San Bernardino & $6.3 \%$ & $9.2 \%$ & $6.9 \%$ \\
\hline Riverside & $6.2 \%$ & $8.2 \%$ & $6.9 \%$ \\
\hline
\end{tabular}

Both counties were very similar in these respects, with men making up roughly 55\%

of the population, were not very diverse with slightly more than $75 \%$ of the population being native born white, and had similar, if not identical rates of illiteracy. Riverside was not remarkably different from San Bernardino in characteristics that appeared in the census, so in order to develop a separate

\footnotetext{
76 U.S. Census of Population and Housing, 1900, 495. U.S. Census of Population and Housing, $1910,174$. U.S. Census of Population and Housing, 1920, 115.

77 The 1910 census began to separate those identified as "white" as either US or foreign born. U.S. Census of Population and Housing, 1880, 382. U.S. Census of Population and Housing, 1890, 404. U.S. Census of Population and Housing, 1900, 495. U.S. Census of Population and Housing, 1910, 174. U.S. Census of Population and Housing, 1920, 115.

78 Illiteracy rates were not recorded by the 1880-1900 census, but retroactive statistics were included beginning with the 1910 census. U.S. Census of Population and Housing, 1910, 174. U.S. Census of Population and Housing, 1920, 115.
} 
identity for itself town leaders chose to focus on class to differentiate it from neighboring San Bernardino.

The Daily Courier's premonition of county division ultimately came true, and in 1893 tiny Riverside County was carved out of portions of San Bernardino and San Diego counties. ${ }^{79}$ The community of Redlands ten miles east of San Bernardino developed a reputation as an even wealthier town. Founded in 1881 and incorporated in 1888 the city marketed itself as the ideal winter weather home for easterners. ${ }^{80}$ By the 1890s, Redlands was regarded as the home of millionaires who looked condescendingly on their neighboring communities, although it remained a part of San Bernardino County. ${ }^{81}$

In many ways, the social shifts in the Inland Empire at the dawn of the twentieth century conformed to historians' observations of urbanizing communities. The influx of laborers to work the region's orange groves, mines and railways led to a shift in labor dynamics as unions were quickly formed. During the early 1900s, railway workers were active in campaigning for better wages from the owners of the Santa Fe Railway, with boilermakers striking in 1902, and boilermakers and machinists walking out again in $1904 . .^{82}$ The 1904 strike saw machinists for the Santa Fe railroad adopt increasingly militant tactics, building a 40-foot observation tower to peer over the tall wooden fences ringing the railway

\footnotetext{
${ }^{79}$ Nunis, Southern California Local History, 345.

${ }^{80}$ Schuilling, San Bernardino County, 86-87.

${ }^{81}$ Schuilling, San Bernardino County, 115.

82 "Strikers Will Get No Raise In Wages," Riverside Daily Press, 7 June 1902, 1. "Boilermakers Joined Machinists on Strike," Riverside Daily Press, 9 May 1904, 1.
} 
yards to watch those workers who refused to go on strike, ultimately beating them in the street once they had left the yard. ${ }^{83}$

While the San Bernardino area's working class identity became more concentrated during the 1890s, Riverside and Redlands drifted towards more middle class values encouraged by wealthy newcomers attracted to the region's warmth. Like many other communities, Riverside enthusiastically embraced the fight for Prohibition and in 1890 the Riverside Daily Press observed a meeting held at the town's 1,000-seat theater, writing, "the announcement that the anti-saloon meeting would be held in the Loring last evening filled every seat in that commodious building and a large number were compelled to stand throughout the meeting." ${ }^{84}$ Riverside's politics were decidedly Republican, with a recap of the 1892 election noting that Benjamin Harrison had secured 810 votes to Grover Cleveland's 384, and the Prohibitionist and Populist candidates garnering 106 and 88 votes, respectively. ${ }^{85}$ During Riverside's battles to establish independence from San Bernardino, Redlands's allegiance to Progressive principles led the Riverside Enterprise to advocate it replacing San Bernardino as the county seat, arguing:

"Just think, for once, of as a lot of progressive people as have settled Redlands, Ontario, Riverside and the other new towns of the county, submitting to the domineering bossing of one man in San Bernardino...the remedy is an easy one if the people will band together. Let the progressive towns band together and move the county seat, and by the same power put the management of public affairs into new hands. Why not move the county seat to Redlands...Redlands people will give the county a court house and lot, and the town would do credit to the county as a county seat." 86

\footnotetext{
83 "Striking Machinists Build a Watch Tower," Riverside Daily Press, 23 May 1904, 3. "Strikers Warm Up At San Bernardino," Riverside Enterprise, 31 May 1904, 3.

84 "'Chestnuts,'” Riverside Daily Press, 3 April 1890, 4.

85 "See Where We Are At," Riverside Daily Press, 15 March 1894, 4.

86 "The San 'Berdoo' Boss," Riverside Enterprise, 21 October 1891, 2.
} 
Clearly, just as San Bernardino had begun to adopt working class, urban values, the communities of Riverside and Redlands had begun to adopt those of middle class, Progressive society.

\section{Conclusion}

As the nineteenth century gave way to the twentieth, the United States was still in the process of urbanization that brought social change to communities across the country. The expansion of small industries into big business brought growing income inequality and class identification, which in turn realigned political ideals. In many ways, the Inland Empire communities of San Bernardino, Riverside and Redlands were the embodiment of these shifts, with the expansion of the city into a railway hub bringing new people and new jobs to the region. As a result of this growth, the cities began to take on their own class and political identities, ultimately leading to Riverside's breakaway from San Bernardino County.

The social changes of the late nineteenth century also radically shifted the demands of American popular entertainment. Vaudeville embraced the new American values of urbanization in a way other forms of entertainment would not or could not. The variety of performers shuffling across stages matched the pace of urban life, captured the urban experience and brought middle class approval and patronage. Yet in many ways vaudeville was an extension or mutation of the many forms of entertainment that had come before it. In order to analyze why vaudeville was the perfect match for twentieth century urban America, it is first necessary to analyze these other forms of entertainment and their shortcomings. 


\section{Chapter 2}

Nineteenth-Century American Popular Entertainment

Nineteenth-century America spawned numerous forms of entertainment that captivated audiences of the day. Some of these forms, such as musicals and the circus, drew on previous traditions, morphed over time in response to popular trends, and remained a part of American popular culture well into the twentieth century. Others such as the dime museum and blackface minstrelsy were popular during the nineteenth century, but fell out of favor by the early twentieth century. Amongst all of these entertainment options, none proved to be as popular as vaudeville, which by 1910 had 2,000 "small-time" theaters spread across the United States with larger theaters such as the Palace Theatre in New York making profits of $\$ 10,000$ per week. ${ }^{87}$

In order to properly contextualize the nationwide embrace of vaudeville, it must be compared to the other entertainment options of its day. Previous scholarship by Albert McLean and Gunther Barth has linked the widespread appeal of vaudeville to the changes taking place in American life during this era of rapid urbanization. By the same token, other forms of entertainment can be explored to note the ways in which they were unable to keep pace with a rapidly shifting nation. Shakespearean plays, minstrel and burlesque shows, comic operas, dime museums, traveling circuses, and tent shows all competed for space within the crowded entertainment marketplace, but by the end of the nineteenth century most catered to narrow niche audiences that were much smaller than that of vaudeville. San

${ }^{87}$ Green, Show Biz, 4. Laurie, Vaudeville, 245. Marian Spitzer, The Palace (New York: Atheneum, 1969), 144. 
Bernardino, Redlands and Riverside all featured these forms of popular entertainment during the late nineteenth century, and the Inland Empire region can be used as a case study to help evaluate and demonstrate the reasons why these entertainment forms were not as successful as vaudeville in capturing the market for urban entertainment.

\section{Other Entertainment in Nineteenth-Century America}

Most forms of entertainment in late nineteenth-century America had their roots in performing traditions that emerged well before the Civil War. In the earliest years of the nineteenth century the most popular entertainers were ballerinas, violinists, and soprano singers, all of whom had yet to assume their sanctified place in American highbrow culture and were popular with the general public. ${ }^{88}$ By the 1820s, acting troupes specializing in the works of Shakespeare began traveling along the east coast, spreading the Bard's popularity across all social classes. ${ }^{89}$ These performers were able to utilize new transportation networks such as canals and roadways to travel hundreds of miles inland and provide settlers of what are now considered the Midwest and Mississippi regions access to the same entertainment as those on the east coast..$^{90}$

These transportation networks also allowed new forms of entertainment being developed in the nation's frontier regions the ability to reach eastern audiences. During the 1820s, urban-born northerners who were enamored with popular entertainment and the music and dance they encountered in African

\footnotetext{
${ }^{88}$ Lawrence W. Levine, Highbrow/Lowbrow: The Emergence of Cultural Hierarchy in America (Cambridge, MA: Harvard University Press, 1988), 108.

${ }^{89}$ Levine, Highbrow/Lowbrow, 17-18.

${ }^{90}$ Sanjek, American Popular Music and Its Business, 154-155.
} 
American communities in the western cities of Louisville, Pittsburgh and Cincinnati spurred the development of blackface minstrelsy. ${ }^{91}$ Eric Lott has argued that minstrelsy appealed to white working class men who feared that they were being viewed as "black" inferiors by the upper classes and resorted to forms of entertainment that emphasized white supremacy over their fellow black laborers. ${ }^{92}$ Minstrel performers traveled across the same networks as earlier "legitimate" theatrical performers had done, and swept across the west back to eastern cities including New York, where by the 1830s such performances had become extremely popular. During the 1830s, minstrelsy positioned itself in opposition to other entertainments such as opera and theater that became associated with the upper classes, creating a divide in popular culture. ${ }^{93}$ In 1843 the first minstrel troupe, Dan Emmett's Virginia Minstrels, was formed in New York, and traveled the country inspiring imitators, all of which helped craft a strong and relatable plantation mythology around themes of lost love, separated families, death, home and nostalgia. Following the Civil War, the minstrel show remained a popular format of entertainment that provided a familiar structure of dance, jokes, songs, instrumental tunes, skits, mock oratory, satire, and racial and gender cross-dressing or impersonation by mostly male performers. ${ }^{94}$

Minstrelsy was only one of several forms of entertainment offered by saloons in urban, working class neighborhoods. During the 1840s and 50s, neighborhoods

\footnotetext{
${ }^{91}$ Eric Lott, Love and Theft: Blackface Minstrelsy and the American Working Class (New York: Oxford University Press, 1993), 47-50.

${ }^{92}$ Lott, Love and Theft, 71.

${ }^{93}$ Lott, Love and Theft, 64.

${ }^{94}$ Lott, Love and Theft, 72, 203, 9.
} 
such as the Bowery in New York were home to a number of these concert saloons, which offered variety acts for 10 to 25 cents, as well as "waiter girls" that drank on the job and occasionally prostituted themselves to the overwhelmingly male audiences. These concert saloons differed dramatically from the bourgeois "respectable" theaters that emerged during this time and appealed to the upper classes, representing their mirror opposite. ${ }^{95}$

Stage actors during this time began to organize the performances in these saloons into what would come to become known as "burlesque" by combining several popular varieties of stage show: travesty, pantomime and extravaganza. ${ }^{96}$ Initially, burlesque performances were simply used to bridge breaks during larger plays, but in 1867 Lydia Thompson a well-known English dancer prepared a fulllength burlesque entitled Ixion for her debut performance in the United States. This burlesque initially opened at the New York dime museum Wood's Theater, dime museums offering nineteenth-century urban audiences additional entertainment detailed later in this section. Audiences loved its lampooning of classical culture, parodies of popular songs, and in particular, chorus lines of dancing girls that featured what Broadway historian Cecil Smith described an "extensive display of the

\footnotetext{
${ }^{95}$ Allen, Horrible Prettiness, 73.

96 Robert Allen has defined each of these elements of early burlesque in great detail. "Travesty aimed at a specific work of high culture, removing its characters from their lofty positions as princes and peers and resituating them in considerably more prosaic settings. Romeo and Juliet were transplanted to Hoboken, for example...Whereas the travesty might or might not involve music, the extravaganza and the pantomime always did. Both these forms drew on myths, fairy tales, and children's stories as frames for contemporary comic allusions, visual humor, dances, spectacles, and popular songs. The pantomime...was distinguished largely by its continued reliance on some vestige of the commedia-del-l'arte traditions of the form: stock characters and situations; a heavy does of broad, sometimes violent slapstick; and the obligatory transformation scene...Extravaganza might include parodies of popular songs and retain the rhymed-couple form of more traditional burlesque, but its humor was diffuse, undirected toward any particular object. As the various forms of burlesque became increasingly loose and intermixed in the $1860 \mathrm{~s}$, the extravaganza came to stand for any inversive, comic, musical spectacle." Allen, Horrible Prettiness, 101-102.
} 
female form," and flocked to performances. ${ }^{97} \mathrm{~A}$ few years later Thompson moved her show to Niblo's, a popular respected theater in New York, but critics attacked the show for being indecent and sexually suggestive; performances that may have been acceptable to Bowery theater goers were unfit for middle class audiences. ${ }^{98}$ By the 1870s, burlesque houses had embraced their niche, working class audience by offering salacious material and blue comedy, both of which were increasingly frowned on by "legitimate" theaters, ${ }^{99}$ a fact noted by Sophie Tucker who began her career singing in burlesque shows during the early 1900s:

"Folks weren't so highbrow they cried for Ibsen and Shakespeare the way babies cried for Castoria in the ads. Folks wanted a belly laugh every so often. They wanted to let down their hair and unbutton their vests and be natural. They wanted to laugh at sex. Sex was funny, not necessarily intense and tragic the way the playwrights such as Ibsen made it out to be. Why, weren't the best jokes in the world the ones that played on sex? And suppose burlesque was 'vulgar,' the way vaudeville said it was. Hell! folks were vulgar. Otherwise burlesque wouldn't be the good business it was, playing to full houses forty-five weeks of the year."100

In response to the seediness of the Bowery's burlesque performances, comic operas also emerged as a popular form of entertainment during the 1850s, and drew on similar traditions such as pantomime and extravaganza, as well as female beauty. In 1866, The Black Crook premiered in New York and became the first blockbuster musical in American history by attracting a high-class audience normally drawn to opera and working class audiences that traditionally attended Bowery shows by presenting a show based around displaying the beautiful legs of

\footnotetext{
${ }^{97}$ Allen, Horrible Prettiness, 3-4, 10, 12. Cecil Smith and Glenn Litton, Musical Comedy in America: From The Black Crook to South Pacific (New York: Theatre Arts Books, 1981), 17.

${ }^{98}$ Allen, Horrible Prettiness, 16, 28.

${ }_{99}$ Allen, Horrible Prettiness, 177, 221.

100 Tucker, Some of These Days, 54.
} 
its female dancers. ${ }^{101}$ Comic operas and musicals remained popular throughout the 1870s and 1880s with the first American productions of Gilbert and Sullivan operas, as well as Edward Harrigan's Mulligan's Guard musicals that offered realistic depictions of urban, working-class life, a fact praised by leading literary critic William Dean Howells. ${ }^{102}$

During the mid-nineteenth century dime museums emerged as a popular venue for middle class families to take in variety shows while avoiding the vice associated with working class theaters. ${ }^{103}$ Dime museums offered quasi-scientific explanations for natural oddities, and also encouraged living "freaks" such as Tom Thumb to perform for live audiences by singing and dancing. ${ }^{104}$ In 1849, P.T. Barnum, owner of the American Museum in New York, opened its Lecture Room to allow stock theater companies to produce dramas, comedies and farces featuring "afterpiece" freak shows. ${ }^{105}$ By the 1880s, theaters became the main draw of dime museums, replacing their exhibits almost entirely, with large museums opening multiple theaters that catered to specific genres such as melodrama and variety. Dime museums also played a crucial role in shaping the administrative development of vaudeville, as future vaudeville mogul B.F. Keith began his career working in dime museums. ${ }^{106}$

\footnotetext{
${ }^{101}$ Smith and Litton, Musical Comedy in America, 2-6, 12.

${ }^{102}$ Smith and Litton, Musical Comedy in America, 35, 39-42. Koger, "A Critical Analysis of Edward Harrigan's Comedy," 148.

${ }^{103}$ Andrew Stulman Dennett, Weird and Wonderful: The Dime Museum in America (New York: New York University Press, 1997), 6. Allen, Horrible Prettiness, 64.

104 Dennett, Weird and Wonderful, 71.

105 Many theatrical performances during the nineteenth century concluded with humorous one-act plays known as "afterpieces" that served to loosen dramatic tension built up during the course of the preceding performance.

106 Dennett, Weird and Wonderful, 35, 101, 103.
} 
Urban centers on the east coast were the most densely populated regions of the country, but towns scattered across the country also had access to emerging stars of the theater. Spurred by the growth of railroads, theatrical touring companies were able to easily travel to newly constructed Opera Houses in towns across the country. The local theaters were called Opera Houses or Academies of Music to distance them from what were often considered scandalous reputations of contemporary theaters. Local Opera House owners and managers handled their booking by traveling to New York during the summer months to personally negotiate since there was no central booking agency for touring theatrical troupes. ${ }^{107}$ These Opera Houses courted respectable middle-class audiences with full-length theatrical plays, and also exposed their audience to variety performers between acts of these traveling shows. ${ }^{108}$

One form of entertainment equally popular in rural and urban areas was the circus. Circuses had emerged in the United States during the eighteenth century from English trick horse riders, but once circus operators began using tents in 1825 they were able to adopt the itinerant performing model that is still common today. ${ }^{109}$ Circus performers traveled in wagon trains for nearly forty years, but it was the cheap rail travel of the 1870 s that led producers such as P.T. Barnum to begin offering large-scale shows across the country. Barnum purchased his own specially designed cars with specialized feeding areas for animals, allowing them to

\footnotetext{
107 William L. Slout, Theatre in a Tent: The Development of A Provincial Entertainment (Bowling Green, OH: Bowling Green University Popular Press, 1972), 2-3, 8.

${ }^{108}$ Slout, Theatre in a Tent, 15.

109 Janet M. Davis, The Circus Age: Culture \& Society Under the American Bigtop (Chapel Hill, NC: University of North Carolina Press, 2002), 16-17.
} 
be transported easily across vast distances. ${ }^{110}$ Circus owners also expanded the size of their tents, allowing acrobats more space to perform incredible feats for an amazed audience. Enterprising businessmen opened more circuses annually, reaching their apex in 1903 when 98 circuses circled the United States. ${ }^{111}$ Circus operators tried to appeal to as wide an audience as possible, but their itinerant nature led to crime and illicit behavior, attracted child runaways, and allowed ticket prices to be higher than other forms of entertainment, all of which created division within communities. ${ }^{112}$

In many ways, the popularity of all of these forms of entertainment can be placed within the context of urbanization. Minstrelsy and the circus had their roots in rural areas during the early nineteenth century, but developments by Dan Emmett and P.T. Barnum, among others, helped reconstitute them for urban audiences. Similarly, art forms such as burlesque or musical theater had their roots in urban concert saloons, and dime museums functioned as theaters in urban America. Rural audiences were integrated into popular entertainment primarily through tent-based theater troupes. ${ }^{113}$ In 1900, there were over 300 tent-based theatrical touring companies catering to rural audiences. These companies were able to market themselves to farmers that had increased farm production and profitability during the 1890 s, providing them with disposable income and a demand for entertainment. Tent shows were a popular alternative during the summer when traditional theaters closed in response to the heat, with some

\footnotetext{
110 Davis, The Circus Age, 20.

111 Davis, The Circus Age, 7.

112 Davis, The Circus Age, 29-34.

${ }^{113}$ Slout, Theatre in a Tent, 35, 49, 51.
} 
companies going as far as to construct wood flooring to provide the impression of a first-class theater. ${ }^{114}$

\section{Limitations and Divisions of Nineteenth-Century Entertainment}

Over the past several decades, scholars have noted the ways in which many of these forms of entertainment were unable to keep up with shifts in American society and how these shifts divided audiences along hierarchical lines. The most famous of these scholars is Lawrence Levine, whose book Highbrow/Lowbrow noted that by the end of the nineteenth century the works of Shakespeare had been divorced from everyday culture and "sacrilized," a process spurred by non-English speaking immigrants who had little connection to his work, and the decline of the romantic idealism embodied by Shakespeare during the 1880 s. $^{115}$ Large theaters were re-ordered during the middle of the century in response to aggressive audience behavior from the working class, leading cultural elites to believe that "legitimate" art was above the understanding of the masses. ${ }^{116}$ An excellent example of this behavior can be found in the response of the mining community of Tombstone, Arizona to one of Shakespeare's plays staged in a local theater in 1885:

"A company of duffers gave a show last night at Barney Hill's. They played a dizzy snap called Hamlet. We never heard of the drama before and we never want to see it again. It is the snidest thing in the way of a show we ever fell up against. There ain't no horses, singing, fighting, or dancing in the whole blamed shebang. There was a lively dog fight in the middle of the play that was a great success. The actors were not killed but the duck that played "Hamlet" was tarred and feathered. He will recover."117

\footnotetext{
114 Slout, Theatre in a Tent, 39-40, 54.

115 Levine, Highbrow/Lowbrow, 33, 47-48.

116 Levine, Highbrow/Lowbrow, 60, 76.

117 (Tombstone) Daily Record-Epitaph, October 22, 1885, quoted in Clair Eugene Wilson, Mimes and Miners: A Historical Study of the Theater in Tombstone (Tucson, AZ: University of Arizona, 1935), 9.
} 
The upper class responded to this behavior by demanding private spaces free from the interference of the masses, created rules of decorum to transform public space, and encouraged the masses to emulate their behavior. ${ }^{118}$

Many scholars have argued that full-length minstrel shows had constraints that began to limit their appeal in relation to vaudeville at the dawn of the twentieth century. Minstrel shows had declined in popularity in New York following passage of the Concert Saloon Bill of 1862, which denied alcohol licenses to venues where curtains separated the audience from performers and barred women from serving as waiters. As a result, minstrel troupes began touring more extensively as similar laws were not widespread outside of New York, crafting a business model predicated around touring rather than ownership or residency at one particular theater. Minstrel troupes were also under pressure from producers of other forms of entertainment, particularly comic operas, which had emerged during the late 1860s and early 1870 s as an exciting new alternative to minstrelsy. ${ }^{119}$ Unlike vaudeville and burlesque shows, which embraced some degree of feminine sexuality on stage, Albert McLean observed that minstrelsy limited its appeal by offering men in drag as the only female characters and made no attempt to offer sex appeal.120 However, while these factors may have helped limit minstrelsy's appeal they did not eliminate it outright, and minstrelsy and blackface entertainment remained a

\footnotetext{
118 Levine, Highbrow/Lowbrow, 177.

${ }^{119}$ Enforcement of this act was never totally successful, but was influential in pressuring theater owners to focus on box office receipts as the key to profit, particularly for Pastor and Keith. Sanjek, American Popular Music and Its Business, 305. 120 McLean, American Vaudeville as Ritual, 28-31.
} 
prominent part of American popular entertainment until well into the twentieth century.

By the end of the nineteenth century producers of both burlesque and comic operas had also developed performance structures that narrowed their perspective audiences. As previously noted, burlesque producers thought it beneficial to deliberately take their shows away from the mainstream and focused on catering to a niche audience; by doing so, they denied themselves the chance to become the leading entertainment of the early twentieth century. Burlesque remained a decidedly urban entertainment, limited to cities in the east, Midwest, and San Francisco, unable to resonate elsewhere. ${ }^{121}$ From a business perspective, burlesque owners also lacked a dominant theater ownership association like vaudeville, making it impossible for owners to develop the monopolistic power wielded by Keith in vaudeville. ${ }^{122}$ Comic operas moved in the opposite direction, and completely merged their art form into legitimate theater for the upper classes. By the early 1900s, Florenz Ziegfeld's Follies conjured up the worldliness of Paris and demonstrated the successful merging of sexuality and musical extravaganza that had eluded burlesque shows. ${ }^{123}$ Sophie Tucker keenly observed this distinction, noting:

"The Follies were 'Class.' They offered Americans something Americans used to think they could get only in Paris, and at prices that lifted this form of variety way out of the vaudeville class. The suggestion of French naughtiness was implied in the name of the special theater, the Jardin de Paris, built on

${ }^{121}$ Allen, Horrible Prettiness, 192.

122 Allen, Horrible Prettiness, 191.

${ }^{123}$ Allen, Horrible Prettiness, 245. 
top of the New York Theatre in Times Square and dedicated to Ziegfeld's venture."124

The other forms of entertainment also had their own limitations that prevented them from becoming as popular as vaudeville with urban American audiences. As previously noted, by the 1880 s, dime museums had primarily become another venue for theatrical productions as urban audiences demonstrated an increased reluctance to accept the quasi-scientific displays of freaks. ${ }^{125}$ Similarly, the itinerant nature of the circus prevented it from planting roots in cities and its performers lacked fresh material that could have kept audiences returning even if it had a base. The circus also suffered because it quickly became associated with children's entertainment, preventing it from being taken seriously by middle class adults. ${ }^{126}$ Finally, urban society had little use for tent shows that came into existence precisely because they were catering to a rural audience.

Vaudeville uniquely positioned itself to nurture differences with legitimate theater that broadened its appeal, yet also embraced elements of legitimate theater that prevented its audience from becoming too fragmented. Vaudeville's audience was often characterized as being much less sophisticated than a legitimate theater crowd. A Keith theater manager noted such biases when he blamed the flop of acclaimed French actress Yvette Cuilbert on the audience, writing, "the majority of vaudeville patrons are not of a class that appreciates her work."127 Theater owners consciously sought to differentiate the fast-paced shows of vaudeville from the

\footnotetext{
124 Tucker, Some of These Days, 65.

125 Barth, City People, 199.

${ }^{126}$ Barth, City People, 199. McLean, American Vaudeville as Ritual, 28.

127 Report Book 10, 28, Keith/Albee Collection, Special Collections Department, University of Iowa Library, Iowa City, IA, quoted in Kibler, Rank Ladies, 2.
} 
perceived slower pace of full-length or long one-act plays, observing that their audiences demanded different things. Another of Keith's theater managers observed a play performed on his stage and wrote, "I suppose that if I was a student of drama I would call this a dramatic gem. From a vaudeville standpoint I think the act is a little slow...not quite suited for the second largest theater in the world."128 Vaudeville's ongoing efforts to differentiate itself from legitimate theater, while at the same time attracting diverse audiences will be examined further in Chapter Three.

\section{Popular Entertainment in the Inland Empire, 1880-1914}

The Inland Empire region of San Bernardino, Riverside and Redlands represents a significant case study of late nineteenth century American popular entertainment because virtually all of the dominant art forms were present in some capacity. As small though rapidly expanding urban areas, these young cities were home to a growing population that demanded entertainment. The main branch of the public libraries for all three cities contain archives for the Opera Houses constructed in each of these neighboring communities. The Opera Houses offered a variety of entertainment and were much more stable than the vaudeville houses that competed with them, making them important venues to study.

The San Bernardino Opera House was the first major theater constructed in southern California, completed in 1881 with financing from local rancher James Waters who had acquired extensive real estate holdings after purchasing land from

\footnotetext{
128 Report Book 12, 113, Keith/Albee Collection, Special Collections Department, University of Iowa Library, Iowa City, IA, quoted Kibler, Rank Ladies, 83-84.
} 
departing Mormon settlers in the late 1850s. ${ }^{129}$ At its opening day performance by Hamilton's Royal Australian Minstrels the theater could seat 900 patrons and in 1890 promoted itself to performers it was attempting to attract by claiming San Bernardino was "the best show town on the coast," with the city's population of 7,000 and the ability to draw crowds from the nearby towns of Riverside and Colton. ${ }^{130}$ After Waters's death his daughter, Martha Kiplinger, became the manager of the theater in the early 1890s, and as one of the only female theater managers of the era cultivated friendships with leading actors and Broadway producers that helped her book acts for the theater. ${ }^{131}$ These clearly helped Kiplinger, who occasionally was able to get bookings over the nearby towns, such as a 1906 performance of Charles Hanford, where it was noted, "in conversation with a representative of The Sun, [Hanford's] Manager Walker stated that this city had the preference over Redlands and Riverside, as he had only one open night, and he gave it to San Bernardino."132 The theater was remodeled in 1912, which expanded the theater to between 1,200 and 1,400 seats and allowed Kiplinger to leave her job as a clerk at the post office and manage the theater full time. By the 1920s, the theater offered more vaudeville shows and eventually became a movie theater before it was sold and demolished in 1927.133

\footnotetext{
${ }^{129}$ Earl E. Buie, "They Tell Me," San Bernardino Sun-Telegram, 20 May 1958. L. Burr Belden, "James Waters Had Big Role in City History," San Bernardino Sun-Telegram, 26 February 1956, 26.

130 Earl E. Buie, "They Tell Me," San Bernardino Sun-Telegram, 20 May 1958. Plato, Lesher \& Hyde advertisement of 1890, quoted in L. Burr Belden, "Gas Lights, Opera House Bring City Ways During 1880s," 28 September 1952.

${ }^{131}$ Earl E. Buie, "They Tell Me," San Bernardino Sun-Telegram, 20 May 1958. "Death Takes Mrs. Kiplinger, Noted Citizen," San Bernardino Sun, 18 August 1942, 9.

132 "Amusements," San Bernardino Daily Sun, 13 March 1906.

133 Earl E. Buie, "They Tell Me," San Bernardino Sun-Telegram, 20 May 1958. "Death Takes Mrs. Kiplinger, Noted Citizen," San Bernardino Sun, 18 August 1942, 9.
} 
Opened in 1890, the Loring Opera House in Riverside shared a similar history to its rival in San Bernardino. The 1,000-seat theater was noted for its luxurious beauty, financed by the former President of Riverside's Chamber of Commerce, Charles Loring, and managed by Frank Miller. ${ }^{134}$ Like Kiplinger in San Bernardino, Miller also sought to cultivate relationships with performers, with one from San Francisco noting that, "in all his travels he never found it so hard to tear himself away from any place as Riverside, and that the great enjoyment he experienced there was due to the thoughtful attentions and generous hospitality of Mr. and Mrs. Miller."135 The theater booked many of the same leading acts that played San Bernardino, occasionally as part of the same tour of southern California. The theater evolved over time, becoming a movie theater for many years before being leased to the city for various municipal uses including as the first City Hall, before ultimately burning down in $1990 . .^{136}$

The Wyatt Opera House in Redlands was the last of the major Opera Houses in the region to be constructed, opening in 1904. Prior to its completion, the town was home to smaller theaters such as the Wilson Opera House that offered a similar blend of entertainments as the other major Opera Houses, but lacked the grandeur leading citizens sought for a community styled the "City of Millionaires." H.C. Wyatt arranged financing for a vibrantly colored theater capable of holding 1,200 to 1,500

\footnotetext{
134 “Local News," Riverside Daily Press, 29 October 1889. "Successful Sale," Riverside Daily Press, 30 December 1889, 4.

135 “Local News," Riverside Daily Press, 26 January 1891, 3.

136 Nina Hiltner, “Loring: The Man Behind the Opera House Name," Riverside Press-Enterprise, 4 December 2010.
} 
patrons. ${ }^{137}$ From the first years of its existence, the Opera House was beset by

financial problems, which by the mid-1910s led Wyatt's son to focus on booking

popular vaudeville entertainers that were cheaper than theatrical performers and

could be secured from recent engagements on the Orpheum Circuit in Los Angeles.

Like the other area Opera Houses, the Wyatt struggled through the 1920s, before

being demolished in 1929.138

These venues offered a variety of shows and performances that would appeal

to diverse audiences. The below table demonstrates the range of different types of entertainment offered at the major Opera Houses.

\begin{tabular}{|c|c|c|c|}
\hline \multicolumn{2}{|c|}{ Table 2.1 - Opera House Performances, 1880-1914139 } \\
\hline Entertainment & $\begin{array}{c}\text { San Bernardino } \\
\text { Opera House }\end{array}$ & $\begin{array}{c}\text { Loring Opera } \\
\text { House/Theatre } \\
\text { (Riverside) }\end{array}$ & $\begin{array}{c}\text { Wyatt Opera House } \\
\text { (Redlands) }^{142}\end{array}$ \\
\hline Acrobat & 2 & - & - \\
\hline Animal Act & 1 & - & - \\
\hline Athlete & 2 & - & - \\
\hline Classical Concert & 5 & 19 & - \\
\hline Comedian & - & 1 & 1 \\
\hline Dance & - & 3 & - \\
\hline Magician & 4 & 2 & 3 \\
\hline Minstrel & 19 & 17 & - \\
\hline
\end{tabular}

137 Bradley Eugene Weisberg, "A History of the Wyatt Opera House," (M.A. thesis, San Diego State University, 1991), 1-2, 9-12.

138 Weisberg, "A History of the Wyatt Opera House," 21-22.

139 The purpose of the chart is to demonstrate the distribution of how often each type of entertainment was performed. This chart is not all-inclusive, but represents a sample based on available sources. Please see Appendix A for a complete listing of all documented performances. 140 Sample collected from articles in The (Redlands) Citrograph from 1889-1893, articles and advertisements in the San Bernardino Daily Courier from 1886-1888 and the San Bernardino Daily Sun from 1894, 1899, 1903-1906, and retrospective columns on the Opera House by Earl E. Buie published in his "They Tell Me" column the San Bernardino Sun-Telegram on 20 May 1958, 27 May 1958 and an undated column, all three located in the "Historic Buildings - Opera House" file in the California Room of the Norman Feldheym Library, San Bernardino, California.

141 Sample collected from programs found in the Loring Opera House and Theatre Program Collection, Riverside Public Library, Riverside, California from 1890-1914.

142 Sample collected from summary of Wyatt Opera House programs holdings at the Heritage Room of the A.K. Smiley Public Library, Redlands, California for 1904-1914 in Weisberg, "A History of the Wyatt Opera House," 37-39, and the Redlands Daily Review from 1909-1913. 


\begin{tabular}{|c|c|c|c|}
\hline \multicolumn{4}{|c|}{ Table 2.1 - Opera House Performances, 1880-1914139 } \\
\hline Entertainment & $\begin{array}{c}\text { San Bernardino } \\
\text { Opera House }\end{array}$ & $\begin{array}{c}\text { Loring Opera } \\
\text { House/Theatre } \\
\text { (Riverside) }^{141}\end{array}$ & $\begin{array}{c}\text { Wyatt Opera House } \\
\text { (Redlands) }^{142}\end{array}$ \\
\hline Musical & 19 & 45 & 29 \\
\hline Opera & 10 & 8 & 8 \\
\hline Play & 181 & 204 & 52 \\
\hline Public Speaker & 2 & 1 & - \\
\hline Singer & 2 & - & 2 \\
\hline Vaudeville & 4 & 4 & 2 \\
\hline Total: & 251 & 304 & 104 \\
\hline
\end{tabular}

At each of the region's Opera Houses, plays made up over half of the shows. The overwhelming frequency with which these venues offered plays suggests these "Opera Houses" more accurately would be considered theaters, a fact not lost on the community. In 1902, the Loring Opera House was actually renamed the Loring Theatre, in what the Riverside Enterprise felt was a direct reflection of popular tastes, writing:

"Owing to the well known fact that nearly every little town that possesses a public hall gives it the magnificent misnomer of 'Opera House,'...Manager Miller has very wisely changed the name of his place of amusement from the 'Loring Opera House' to the more appropriate 'Loring Theatre,' and it will hereafter be known officially by this title. This is following in the footsteps of all the principal places of amusements in the large cities, and shows that Manager Miller and his popular theater are up with the times." 143

Clearly, in these communities the designation "Opera House" suggested a desire by theater owners to fit into a social landscape that demanded middle class respectability from popular entertainment, and the renaming of the Loring Theatre suggests social moods began to change in the early twentieth century. Appeals to the respectable classes could be seen in the pricing for shows, which were similar in each city, though they occasionally varied based on performer. Shows typically

143 “Loring Theatre is its Official Title," Riverside Enterprise, 16 February 1902, 1. 
fetched ticket prices beginning at 25, 50 and 75 cents, topping out at $\$ 1$ and $\$ 1.50$ for the best, non-box seats, and a substantial increase over the 15, 20 and 25 cent tickets charged at vaudeville theaters. ${ }^{144}$ Ads for consumer goods often lay next to those for local theaters in the region's newspapers and provide some context for how reasonable the cost of a night's entertainment was; solid gold buttons emblazoned with the logo of any fraternal organizations cost 75 cents, 1,000 cubic feet of gas from the San Bernardino Gas \& Electric Co. cost \$1, and women’s French flannel shirtwaists were on sale for \$1.49.145

Reviews of the plays, operas and musicals depict rapidly urbanizing communities and hint at emerging class differences. An unidentified reviewer described the audience for a performance of Shakespeare's "Merry Wives of Windsor," as being taken, "almost to a society function, as the beauty, refinement and wealth of San Bernardino and adjoining towns thronged the house, and became more and more enthusiastic as the rendition progressed."146 Grand theatrical spectacles on stage mirrored the opulence of the crowd, with reviews regularly praising the elaborate costuming and staging. ${ }^{147}$ While Shakespearean plays were popular with high society, they did not always resonate with wide audiences, as the review of a 1906 production noted, "Shakespearean lovers are still summering,

\footnotetext{
144 Brodway Theatre Advertisement, San Bernardino Daily Sun, 31 August 1906. San Bernardino Opera House Advertisement, San Bernardino Daily Sun, 15 September 1906. Loring Theatre Advertisement, Riverside Enterprise, 19 September 1907, 1. Weisberg, "A History of the Wyatt Opera House," 12.

145 Manson \& Bay Advertisement, San Bernardino Daily Sun, 23 January 1906. San Bernardino Gas \& Electric Co. Advertisement, San Bernardino Daily Sun, 3 January 1906. Cartwright's Advertisement, San Bernardino Daily Sun, 18 January 1906.

146 "Amusements," San Bernardino Daily Sun, 25 November 1906.

147 "Week with the Players - Modjeska Last Night," San Bernardino Daily Sun, 11 February 1906. "Amusements," San Bernardino Daily Sun, 18 February 1906. Weisberg, "A History of the Wyatt Opera House," 32.
} 
perhaps, for under ordinary circumstances the 'Merchant of Venice' would have called for a houseful of enthusiasts, but hardly so last night. The numbers were only what might have been called fair."148 Audiences in the area were discerning, and reviewers captured their waning enthusiasm for material they felt was derivative or lacked excitement, such as a review for "A Trip to Chinatown," which noted that, "there was a large audience gathered in response to past reputation, but their laughter was like a boy whistling through a graveyard. As to the play, it was a mere skeleton of its former self, with even the bones crumbling to decay."149

Yet for all of the hints that point towards cultural division, other reviews suggest that a more dynamic, democratic society was still in place, helping to illustrate communities still grappling with the changes outlined in Chapter One. Though some reviewers had complained about material being overly familiar and stale, other audiences complained when performances changed too rapidly to material outside of popular tastes. The 1899 review of "A Night in Venice" provides an excellent example of this, as the reviewer remarked, "There is more opera and less music in A Night in Venice than anything bearing the name which has been produced in San Bernardino since the year 1. Nobody will be whistling airs and nobody will be humming any strain from the opera on the streets today...the opera was all wrong, and that's the end of it."150 While performances were often designed to appeal to urban audiences, those that recalled country life were still popular. The 1906 review of "Uncle Josh Perkins" referred to it as a "rural play," and though the

\footnotetext{
148 "Amusements," San Bernardino Daily Sun, 20 September 1906.

149 "Amusements," Riverside Enterprise, 27 February 1903, 6.

150 “Amusements," San Bernardino Daily Sun, 6 May 1899.
} 
reviewer felt the plot was fairly generic, he ultimately conceded, "On the whole, however, it was a fairly good show, and the audience seemed to like that kind of a play. There was a good house in evidence."151 Plays also reflected popular tastes by incorporating skilled vaudeville performers into the action, which suggests a need to attract and retain audiences with a variety of social and economic backgrounds. The review for 1900's "A Knotty Affair" suggests that plays were written as a way to place vaudeville performances on stages reserved for middle class audiences, explaining:

"The piece was evidently written with a liberal license for the interpolation of specialties, which Mr. Dailey has used to the utmost limit. The musical part of the entertainment was a special feature and introduced a number of vaudeville people in topical songs who are above the average. Clever dancing and acrobatic specialists were introduced."152

The continued popularity of minstrelsy at local Opera Houses suggests it had moved beyond its initial working class appeal and become accepted more broadly by society, a fact reinforced by prices that mirrored those offered for other forms of entertainment. ${ }^{153}$ By the early twentieth century several local minstrel troupes had formed, often under the aegis of Elks or other social clubs, and were very popular amongst their communities, so popular that local clubs staged minstrel shows as benefits to raise money for victims of the 1906 San Francisco earthquake. ${ }^{154}$ These troupes included a troupe consisting entirely of women in blackface, the Refined Darktown Lady Minstrels, who were greeted with overwhelming praise, and

\footnotetext{
151 “Amusements," San Bernardino Daily Sun, 18 November 1906.

152 “Amusements," Riverside Daily Press, 22 September 1900, 4.

153 Loring Opera House Advertisement, Riverside Daily Press, 5 January 1901, 3. San Bernardino Opera House Advertisement, San Bernardino Daily Sun, 10 January 1904. 154 "City and County," The (Redlands) Citrograph, 19 November 1904, 7. Elks' Minstrels Advertisement, San Bernardino Daily Sun, 20 April 1906.
} 
attracted well-to-do members of San Bernardino. ${ }^{155}$ Beyond the minstrel show, audiences also embraced blackface performers in stage plays, with a 1906 review for “Uncle Tom's Cabin," explaining, "audiences laughed at the antics of the slaves, were convulsed at the particular ways of Aunt Ophelia, and wept with Little Eva and Uncle Tom, just as they did 40 years ago."156 While minstrel shows were popular, there also is evidence to suggest that the community did not uniformly embrace these shows. A 1900 production of "Mott's Colored Aristocracy" was deemed a successful show, but the reviewer noted a division of the audience, writing, "The gallery of the Loring was crowded last night, but the house down stairs was rather light."157 The gallery offered the cheapest seats in the theater, and crowds here but not in the more expensive seats imply that the working classes were more interested in this particular show.

Entertainers did not always come to town to perform at the Opera Houses, a fact that is certainly true of those that arrived with the circus. The circus offered a variety of different entertainments for the price of 50 cents, which placed it well below the cost of a ticket to a show at the Opera House, but above vaudeville. ${ }^{158}$ The main appeal of the circus was spectacle, which began the moment the circus arrived in town when gigantic animals paraded down public streets to attract attention for the shows, and "people came in from the country by wagon and train and the town presented a regular holiday appearance."159 The varying circuses that came to town

\footnotetext{
155 “Darktown Minstrels Score a Big Hit," San Bernardino Daily Sun, 29 April 1899.

156 "Amusements," San Bernardino Daily Sun, 11 December 1906.

157 "Amusements," Riverside Daily Press, 19 December 1900, 3.

158 The Great Wallace Circus Advertisement, Riverside Daily Press, 13 September 1895, 4. Norris \& Rowe Circus Advertisement, Riverside Enterprise, 12 March 1904, 10.

159 “The Big Show," Riverside Daily Enterprise, 5 November 1898, 3.
} 
all promoted the variety of their performers, which included clowns, acrobats, animal acts and music, with much attention focusing on the exotic, foreign origins of the performers. An article outlining new additions to the Norris and Rowe circus focused solely on a new Japanese acrobatic act, explaining:

"The Oka troupe have performed before the Mikado...They perform intricate feats with a brilliancy, dash and daring that is pleasing to the eye. Their picturesque flowing robes, beautifully wrought with the handiwork which only the deft fingers of the Japanese seem to fashion, are soon discarded for the red tights and white trunks which give greater freedom." 160

The skill of the performers was overlooked by some commentators in the region who saw the circus as children's entertainment, writing, "The 'kids' were glad it was Saturday, for otherwise they might have missed the splendid parade...it would have been worth letting school out anyhow."161 However, this view was not uniform, as another reviewer reflected on several types of entertainment offered by the circus that were appropriate for adults, noting, “There is hardly an act that wouldn't make a fortune at the Orpheum." ${ }^{162}$ Overall, the circus in the Inland Empire provided variety entertainment that differed from vaudeville mainly because of its limited, annual engagements, and appealed to similar, urbanized audiences.

\section{Conclusion}

Popular entertainments of the nineteenth century continued to have a strong presence in Inland Empire communities of the late nineteenth and early twentieth centuries. Yet the community was clearly at a crossroads, as a number of competing impulses brought by urbanization slowly were pushing local society towards an

\footnotetext{
160 "Amusements," San Bernardino Daily Sun, 13 November 1904.

161 "Dog and Pony Show Here Today," Riverside Daily Press, 19 March 1904, 8.

162 "Barnum and Bailey Circus," Riverside Enterprise, 6 September 1905, 8.
} 
embrace of cultural division. On the one hand, Opera Houses in some ways represented trends toward democratic impulses by staging popular plays and musicals to such a degree that the Loring Opera House was eventually rechristened the Loring Theatre. On the other hand, reviewers noted increasing division in the audiences, with certain shows attracting either well-dressed, upper-class crowds, or audiences concentrated in the cheap seats of the gallery. The plays of Shakespeare gradually were becoming less popular, but Italian operas were still accepted by wide audiences. In short, by the early twentieth century the Inland Empire was gradually embracing a hierarchical division of culture, but this transformation was still unfolding. 


\section{Chapter 3 \\ Vaudeville in the Inland Empire}

Talented vaudeville performers offered urban Americans fast-paced, variety entertainment that matched their lifestyle better than other forms of popular entertainment. Attracting customers by the million, big-time vaudeville producers enforced standards designed to appeal to middle class respectability. However, in doing so, vaudeville contributed to deepening social and cultural divisions in American society.

Like many small but rapidly growing American cities of the early twentieth century, the Southern California cities of San Bernardino, and to a lesser extent Riverside and Redlands, began opening vaudeville theaters in the early twentieth century. Prior to 1914 these Inland Empire communities were considered "small time" and struggled to attract the biggest stars of the day. However, a number of competing vaudeville theaters vied for patrons in the expanding Southern California entertainment marketplace. While they could not attract top draws, these theaters offered up an abundance of vaudeville performers, adopted policies akin to big time theaters, and in many ways fit into the broader American model of vaudeville.

\section{Vaudeville, Cultural Hierarchy and Social Division}

Chapter One noted that vaudeville matched urban America's values and lifestyle and became the preferred entertainment option at the dawn of the twentieth century. From its outset, entrepreneurs and producers including Tony Pastor and B.F. Keith sought to make vaudeville a respectable form of entertainment to appeal to a broad and diverse audience. Keith specifically sought to build an audience that crossed class lines, as attested by the opening of the New Boston 
Theatre in 1894 where an actress recited a poem promising "all are equal here," and that the theater would recognize "no favorites, no class."163 In her autobiography, Mae West reflected on her early vaudeville career and recalled that these "equal" audiences did not always intermingle, writing, "I usually found that one night a week you would get a top society crowd, and another night you'd get mostly working class people. Other nights there would be family groups." ${ }^{164}$

While vaudeville was popular across a broad range of social classes, it also contained the fault lines of social division that ran through other aspects of American life. Keith was very conscious of class distinctions, and patriarchally hoped to use vaudeville to uplift the tastes of lower classes and refine women. ${ }^{165}$ Martin Beck, the owner of the Orpheum theater chain which served as the main big time vaudeville circuit west of Chicago, had a similar view, believing it was okay to stage acts he considered to be of artistic quality that flopped since this served as a way to educate the audience. ${ }^{166}$ By the end of the 1890s, Keith claimed that his introduction of basic rules of decorum had succeeded in improving the character of the audience, echoing a change in broader private spheres of American life where rules of etiquette had taken hold; activities such as coughing, spitting, nose blowing and urinating quickly became unsuitable for public, while etiquette books advised readers to behave quietly and inconspicuously in public thoroughfares. ${ }^{167}$

\footnotetext{
163 Levine, Highbrow/Lowbrow, 77.

${ }^{164}$ Mae West, Goodness Had Nothing to Do With It: The Autobiography of Mae West (New York: Belvedere Publications, Paperback Edition, 1981), 49.

165 Kibler, Rank Ladies, 28, 32.

166 Laurie, Vaudeville, 362.

167 Levine, Highbrow/Lowbrow, 195, 198-199.
} 
Perhaps as a result of Keith's successful campaigning, by the end of the 1890s it was no longer common for performers to approach their work with the belief that they must educate their audience, instead favoring the assumption that the audience would bring their own knowledge to the performance. ${ }^{168}$ As the incentive for performers to serve as educators declined and the drive towards entertainment accelerated, scholars such as John DiMeglio and Lawrence Levine have noted that vaudeville no longer made an effort to be intellectually engaging, and as a result, "the cultural fare that was actively and regularly shared by all segments of the population belonged ipso facto to the lower rungs of the cultural hierarchy."169 DiMeglio harshly observed the effect of vaudeville's refusal to engage in anything beyond popular entertainment for the masses, writing, "where social issues and original drama would appeal to the intellect, vaudeville maintained a hands-office policy...In effect, did vaudeville retard the intellectual growth of the nation? Vaudeville was a mirror image of its public, reflecting a country that was evidently content to be socially and intellectually mediocre."170 Alison Kibler observed that because vaudeville quickly came to be dominated by performers catering their acts towards very broad audiences, producers became reluctant to book acts that could be considered "highbrow," fearing that it would cut into profits, and led producers to look down on their audiences. ${ }^{171}$ As a result, vaudeville, despite being an entertainment for the masses, came to occupy a middle rung in an emerging cultural

\footnotetext{
168 Levine, Highbrow/Lowbrow, 216.

169 Levine, Highbrow/Lowbrow, 234.

170 DiMeglio, Vaudeville U.S.A., 198.

171 Kibler, Rank Ladies, 38, 42, 45.
} 
hierarchy, below "legitimate" theater productions, but above forms such as burlesque that catered to a niche, male audience.

Other fault lines of social division also emerged within the vaudeville structure, most notably a distinction between "big time" and "small time" vaudeville theaters. Sophie Tucker succinctly recalled the difference between big and small time in her memoir, noting, "Two shows a day instead of three. Top prices, one dollar and a half. And every bill with two or three - occasionally four headliners." ${ }^{\prime 72}$ From the perspective of vaudeville performers, the main difference between big and small time theaters was the number of shows they were required to perform every day. At some small time theaters, performers were required to work as many as six shows a day. ${ }^{173}$ Big time theater chains, such those operated by Keith and Beck, operated theaters such as Keith's aptly named New York flagship, the Palace Theatre. These opulent theaters naturally demanded expensive tickets, and provided the highest quality entertainers for their audiences. As a result, big time theaters attracted urban white-collar workers, while small time theaters were popular with urban working class audiences or those living outside of major cities. ${ }^{174}$

Performers noted that there was a definite distinction between big and small time audiences. Will Ahern recalled tailoring his acts to specific audiences and their perceived sensibilities, noting:

"The singer in vaudeville learned the tastes of his public in each area and would give it the songs it liked best. Same thing applied to an even greater

172 Tucker, Some of These Days, 88.

173 Kibler, Rank Ladies, 18.

174 Kibler, Rank Ladies, 26. 
extent in comedy. In the South, for example, they were a little slow in getting material. So you had to work slower. In the steel and coal mining areas of Pennsylvania and the Virginias, where many of the workers were foreign, you had to broaden and enunciate your material. But in the key cities - New York, Boston, Chicago - you'd do everything with a snap because they were show-wise."175

These observations were commonplace, and were echoed by performers such as Jack Haley and George Cohan. Yet it would be incorrect to assume that performers' acts and material were totally isolated from small time audiences. While it was nearly impossible for small time theater owners to hire major stars, they often hired impersonators that offered to perform popular acts for a much lower price. Songs, monologues and jokes were published in trade papers like Madison's Budget and McNally's Bulletin, and marketed to performers for direct incorporation into their acts. Cohan recalled the popular "Running for Office" monologue by Aaron Hoffman was seen, "in all the principal cities from New York to San Francisco."176 Offering popular material was a sure way to maintain profitability, and small time producers sought ways to feature the biggest draws of the day.

\section{Vaudeville in the Inland Empire}

The Inland Empire communities were small time vaudeville markets during the early twentieth century. Neither Redlands nor Riverside appears to have had long-lasting or stable vaudeville theaters, although local community groups were fond of providing vaudeville performances. A 1905 article in the Citrograph documented a well-received performance by members of the Redlands country club

\footnotetext{
175 Bill Smith, The Vaudevillians (New York: Macmillan, 1976), 55.

176 George M. Cohan, Twenty Years on Broadway, and the Years It Took to Get There: The True Story of a Trouper's Life from the Cradle to the "Closed Shop" (Westport, CT: Greenwood Press, Paperback Edition, 1971), 193.
} 
that featured community members performing songs and a burlesque of the popular play “The Lady of Lyons." ${ }^{177}$ Local vaudeville performers were also used as a marketing tool to help attract visitors to community hotels. An 1899 advertisement for vaudeville at Harlem Springs, located between San Bernardino and Redlands, promised a "clean, respectable show, including Farces, Monologues, Sketches and the Latest Songs on the Orpheum Circuit."178 These local shows attempted to mimic the entertainment being offered by big time vaudeville, guaranteeing the respectability of their performances and providing popular hits that had been successes around the country. In 1909, the Airdome was opened in Redlands, which offered entertainment every day of the week, but only illustrated songs and moving pictures, making no effort to offer a full vaudeville show. ${ }^{179}$ Advertisements suggest that in February 1905 a theater called the Orpheum Theatre was in operation in Riverside, although further details of this theater could not be located, suggesting it was only open for a brief period of time. ${ }^{180}$

In contrast to Redlands and Riverside, the working class city of San Bernardino had several verifiable vaudeville theaters during the early twentieth century, but many struggled financially and closed rapidly. Two of the more stable theaters in San Bernardino were the Orpheum and Broadway Theatres, which opened in 1903 and 1904 respectively. Harry Deets, who had previously operated the Orpheum Theatre in Los Angeles, operated the Orpheum and aligned it with the

\footnotetext{
177 “City and County," The (Redlands) Citrograph, 7 January 1905, 7.

${ }^{178}$ Harlem Springs Advertisement, San Bernardino Daily Sun, 7 July 1899.

179 Airdome Advertisement, Redlands Review, 21 September 1909, 6.

180 Broadway Theatre Advertisement, San Bernardino Daily Sun, 26 February 1905.
} 
small-time, nationwide Loverick, Lubelski and Levy circuit. ${ }^{181}$ Unfortunately, the theater was closed by Christmas 1904 when Deets was removed to the California Sanitarium, and his wife was unable to care for him and operate the theater at the same time. ${ }^{182}$ The Broadway Theatre lasted in San Bernardino for a much longer period, but was often beset by financial problems and changed ownership and names at several points during its existence. In December 1904, the same month the Orpheum closed, the Broadway temporarily closed due to financial problems, which shocked locals as it had consistently drawn large crowds. ${ }^{183}$ In 1906 it was sold to J.E. Vieno who was aligned with the west coast Sullivan-Considine circuit and extensively remodeled the theater. ${ }^{184}$ The Sullivan-Considine circuit was always in financial troubles, as its expansion revolved around mortgaging prior theaters to pay for new buildings or acquisitions, a risky proposition that led to the rechristening of the theater the Unique Theatre in 1907.185 Ultimately the theater was repurposed for film, renamed the State Theater, and demolished in 1958. ${ }^{186}$

As a major hub on nationwide rail networks San Bernardino's theater owners frequently booked acts out of San Francisco. ${ }^{187}$ At the time, San Francisco was a hotbed of vaudeville talent, and Sophie Tucker described the scene around 1910:

"San Francisco in those days had a lot of great entertainers. Al Jolson was playing there. Mary Lewis was singing at 'Tait's.' Others I remember were

\footnotetext{
181 "Minstrels to Swell White Monument Fund," The San Francisco Call, 24 April 1901, 2. "Splendid Coup by the Orpheum," San Bernardino Daily Sun, 30 June 1904.

182 "Orpheum Closes Last Evening," San Bernardino Daily Sun, 13 December 1904.

183 "Broadway Theater Closes Down Last Night," San Bernardino Daily Sun, 28 December 1904.

184 "Broadway Theatre Under New Management," San Bernardino Daily Sun, 2 October 1906.

"Improvements Planned for Broadway," San Bernardino Daily Sun, 11 October 1906

185 Frank Cullen, Vaudeville Old \& New: An Encyclopedia of Variety Performers in America (New York: Routledge, 2007), 1074.

186 Earl E. Buie, “They Tell Me," San Bernardino Evening Telegram, 28 March 1958, B-6.

187 “San Bernardino's New Vaudeville Play House," San Bernardino Daily Sun, 31 March 1904.
} 
Lee Lloyd, Baby Ruth, the Three White Kuhns, and that swell song, dance, and comedy team Blyler and Brown. Jimmy Blyler and Fred Brown were doing their act in Nome, during the Klondike Rush, when Rex Beach saw them. He brought them to Frisco, where they were a terrific hit." 188

The entertainers mentioned by Tucker all grew to become major names in American entertainment by the 1920s. By being connected to this network vaudeville theaters in San Bernardino were given the chance to grow beyond their small time status, although this process took several years, with most major performers arriving well after 1914.

As a small-time market, San Bernardino struggled to attract top name performers. The Sullivan-Cosdine and Loverick, Lubelski and Levy circuits did not have a strong enough pull to attract many of the biggest headliners to the city, particularly prior to 1910 . Isabella Patricola, a talented singer and violinist, played the Broadway Theatre for two weeks in $1906 .{ }^{189}$ She eventually went on to headline at the Palace Theatre in New York, but at this stage in her career she was not very well-known, sang songs that were not very popular, and was billed in the undesirable second position where she would have to calm an audience that was often bored by the first act and had to contend with late arrivals to the theater. ${ }^{190}$ The performances of Fatty Arbuckle and Mabel Normand at the Unique Theatre during 1913 or 1914 were of much greater consequence, as they were established performers, only a few years away from their big break in silent films. However, these productions were memorable more for what these future stars would become, rather than what was presented onstage. In the 1950s, local columnist Earl E. Buie

\footnotetext{
188 Tucker, Some of These Days, 103.

189 Broadway Theatre Advertisement, San Bernardino Daily Sun, 29 May 1906.

190 Cullen, Vaudeville Old \& New, 869-870.
} 
described the memorable yet simple show from his youth, writing, "Arbuckle, rolypoly fat and young, hadn't learned a thing save falling on his backside, but he got laughs. Miss Normand, young and attractive, was the butt of the ribald jokes of the alleged comedians of the troupe. There was no chorus but everybody in the cast sang a bit and did a little tap dancing, just as the occasion required."191 Unfortunately, Buie does not delve further into the specifics of their act to discuss the jokes that apparently rubbed his youthful morality the wrong way.

Table 3.1 outlines the frequency with which certain types of performers appeared on stage in San Bernardino.

\begin{tabular}{|c|c|c|}
\hline \multicolumn{2}{|c|}{ Table 3.1 - Vaudeville Performances, 1903-1907192 } \\
\hline Entertainment & $\begin{array}{c}\text { Broadway/Unique/State } \\
\text { Theatre, San } \\
\text { Bernardino' }\end{array}$ & $\begin{array}{c}\text { Orpheum Theatre, } \\
\text { San Bernardino }\end{array}$ \\
\hline Acrobat & 24 & 6 \\
\hline Animal Act & - & 7 \\
\hline Barrel Jumper & - & 1 \\
\hline Child Act & - & 1 \\
\hline Chinese Impersonator & 2 & - \\
\hline Chinese Singer & 2 & - \\
\hline Comedian & 38 & 23 \\
\hline Cyclist & 2 & 1 \\
\hline Dancer & 24 & 13 \\
\hline Equilibrist & 6 & 3 \\
\hline Female Impersonator & 3 & 2 \\
\hline
\end{tabular}

191 Earl E. Buie, “They Tell Me,” San Bernardino Evening Telegram, 28 March 1958, B-6.

192 The purpose of the chart is to demonstrate the distribution of how often each type of entertainment was performed. This chart is not all-inclusive, but represents a sample based on available sources. Please see Appendix B for a complete listing of all documented performances. The date range of this sample was considerably smaller than the sample taken for Table 2.1 because of a limitation in primary sources since it was difficult to locate microfilm or hard copies of the San Bernardino Daily Sun after 1907. While other theaters briefly operated in the San Bernardino during the years 1903-1907, they closed much too rapidly to create anything resembling a representative sample size.

193 Sample collected from articles and advertisements in the San Bernardino Daily Sun from 19041907.

194 Sample collected from articles and advertisements in the San Bernardino Daily Sun from 19031904. 


\begin{tabular}{|c|c|c|}
\hline \multicolumn{1}{|c|}{ Table 3.1 - Vaudeville Performances, 1903-1907192 } \\
\hline Entertainment & $\begin{array}{c}\text { Broadway/Unique/State } \\
\text { Theatre, San } \\
\text { Bernardino }\end{array}$ & $\begin{array}{c}\text { Orpheum Theatre, } \\
\text { San Bernardino }\end{array}$ \\
\hline Freak & - & 1 \\
\hline Gypsy Musician & - & 1 \\
\hline Illustrated Singer & 42 & 21 \\
\hline Impersonator & 9 & 2 \\
\hline Japanese Juggler & 1 & - \\
\hline Juggler & 7 & 4 \\
\hline Magician & 9 & - \\
\hline Mechanical Doll & - & 1 \\
\hline Mexican Acrobat & 1 & - \\
\hline Blackface/Minstrel & 17 & 8 \\
\hline Monologist & 8 & 3 \\
\hline Musical & 1 & - \\
\hline Musician & 27 & 4 \\
\hline Novelty Act & 9 & - \\
\hline Play & 17 & - \\
\hline Punching & 2 \\
\hline Quick Change & 1 & - \\
\hline Rifle Shooter & 1 & - \\
\hline Singer & 49 & - \\
\hline Sketch & 79 & 20 \\
\hline Soubrette & 11 & 55 \\
\hline Ventriloquist & 1 & 11 \\
\hline Total & 393 & - \\
\hline & & 188 \\
\hline
\end{tabular}

The vaudeville performers sampled in Table 3.1 differ in many respects from those at local Opera Houses sampled in Table 2.1. As would be expected from an art born out of variety entertainment, vaudeville shows in San Bernardino offered a much greater range of performances than the cross-town Opera House. Additionally, vaudeville shows featured a more even distribution of performance styles; while comic sketches and musical acts were the most common in vaudeville shows, they did not make up over half of the performances like plays did at the Opera Houses. 
Singers were very popular, and unlike the classically trained vocalists performing at the Opera Houses, they often sang new, popular songs and could be accompanied by illustrated slides depicting the lyrics being acted out. Singing was also used by comic teams, coupled with dancing, or even incorporated into novelty acts, providing variety not just from other performers, but also within their own acts. A summary of the acts performing at the Broadway Theatre in October 1904 offers a glimpse at the variety present amongst musical performers:

"Holmes and Deane make up a new team that will furnish the musical novelty act, promising to pull melody out of almost any old thing. The Schiller brothers, one a violin virtuoso and both sweet singers, are mere lads who have created something of a sensation on the vaudeville stage farther east on the circuit. The third musical team is styled the Jamisons, who sing and dance their way into favor on every stage where they appear."195

Those acts billed as musicians also differed significantly from the classical musicians appearing in Opera Houses, focusing on novelty, tricks or unique instruments to entertain the audience. Memphis Kennedy brought a "Den of Wild Instruments," to his performances, Lizzie Welles was a "clever juvenile trick pianist," and Varden, Perry, Wilser were the "Novelty Musical Trio - The Original Rag Time Players."196 Soubrettes, a subset of singers, were significant in that they served as a major fault line in differentiating between the high and low culture of vaudeville and the Opera House. The term soubrette was traditionally applied to flirtatious or sexually suggestive stock characters in operas and musicals, but in vaudeville came to mean

\footnotetext{
195 "At the Playhouses," San Bernardino Daily Sun, 9 October 1904.

196 Broadway Theatre Advertisement, San Bernardino Daily Sun, 27 December 1904. Broadway Theatre Advertisement, San Bernardino Daily Sun, 25 April 1905. Broadway Theatre Advertisement, San Bernardino Daily Sun, 16 May 1905.
} 
a singer who sang of sex boastfully or mockingly for comic effect.197 In San

Bernardino Olive Hare was billed as "a dashing soubrette who is said to be charming both in appearance and voice. She sings catchy songs and does 'tweentimes' dances." ${ }^{198}$ Soubrettes on the vaudeville stage represented a pull towards the lower culture often associated with burlesque, but while sexually suggestive were not as overt as burlesque performances. However, burlesque sensibilities did creep onto the local vaudeville stage, with M'Lain and M'Lain billing their May 1905 act as "burlesque sketch artists," although what this act contained is not described in the advertisement. ${ }^{199}$

For all of the major differences between high and low culture that were emerging in San Bernardino during the early twentieth century, vaudeville theaters also contained a number of performers very similar to those appearing at the local Opera Houses. Vaudeville theaters occasionally brought acting troupes to San Bernardino where they could perform full-length plays, much like the Opera Houses. During the summer of 1906, the hot months when theaters traditionally lay empty due to difficulty attracting crowds willing to bear the heat, the Broadway Theatre featured the Empire Theatre Company for seven consecutive weeks, offering a different play every week including the popular favorite Uncle Tom's Cabin. ${ }^{200}$ Local theaters regularly featured sketches, which often were simple one-act comic plays that could fit within the variety structure of a vaudeville bill. One description of a September 1904 bill at the Broadway Theatre notes the variety offered in each

\footnotetext{
197 Cullen, Vaudeville Old \& New, 1056.

198 “Amusements," San Bernardino Daily Sun, 15 May 1904.

199 Broadway Theatre Advertisement, San Bernardino Daily Sun, 23 May 1905.

200 “Amusements," San Bernardino Daily Sun, 7 August 1906.
} 
sketch, and ethnic characters that were often depicted: "The Randolphs are a comedy knock-about sketch team, and precipitate rounds of applause and good nature in their sketch 'Fun in a China Wash House.'...Fairburn and Caines, a clever sketch team lately from England, will present their very funny travesty, 'An Irish Recruit,' introducing straight shoe dancing and Irish clog, are to appear for the first time."201

Local theaters employed comedians who adhered to nationwide vaudeville standards of good taste, standards that were an appeal to middle class sensibilities and audiences. A multi-week engagement of the Rudwin company offered a series of full-length plays, including Where is Tompkins? which could gratify the senses as, "comedy of the cleanest and most pungent sort bubbles from every line."202 The La Petite Theatre, whose name also unfortunately indicates its impact in the community, ran ads that were more explicit appeals towards respectability, describing itself as, "a continuous performance theatre presenting an hour of refined and moral entertainment, catering to the patronage of Ladies, Children and Gentlemen."203

Vaudeville also found some similarities with Opera House productions that focused on the display of exotic peoples. Although nowhere nearly as popular as plays at the Opera Houses, blackface minstrel performers were very common at San Bernardino vaudeville houses. Unlike the full-length minstrel shows that were performed at the Opera Houses, vaudevillians performed shorter sets, focusing on a

\footnotetext{
201 “Amusements," San Bernardino Daily Sun, 25 September 1904.

202 “Amusements," San Bernardino Daily Sun, 19 April 1906.

203 La Petite Theatre Advertisement, San Bernardino Daily Sun, 25 September 1906.
} 
specialized skill, rather than the variety format common in longer performances. Performers were billed as blackface singers, blackface comedians, blackface female impersonators, and included Malcolm, a blackface juggler and magician, whose act came with the warning that, "ladies who wear diamonds had better don their paste set when they come to the Orpheum, for Malcolm considers it no trick at all to make a change of that kind when he sees the real thing, and he ought not to be tempted." 204

San Bernardino's vaudeville theaters also offered other popular depictions of ethnic stereotypes including German, Jewish, and Irish Americans that were popular around the country. More interestingly, San Bernardino's vaudeville theaters also offered up Chinese and Japanese ethnic stereotypes; the Opera Houses had regularly offered performances of the popular Gilbert and Sullivan comic opera The Mikado, but vaudeville performances offered a differing depiction of Asian culture. As noted in Chapter One, the late nineteenth century was an era of increasing suspicion of immigrants and racial fears. During the early twentieth century the Chinese were the only ethnic group legally barred from entry to the United States under the Chinese Exclusion Act of 1882, and a 1907 "Gentleman's Agreement" between Japan and the United States blocked the immigration of unskilled Japanese workers. As noted in Table 1.4, the population of Chinese and Japanese residents of San Bernardino and Riverside counties was among the lowest of any ethnic group from 1900-1920, and the Chinese population actually fell during this time. From the brief descriptions provided in newspaper articles it is hard to get a sense of how Chinese

204 “Amusements," San Bernardino Daily Sun, 3 July 1904. 
and Japanese identities were physically acted out in vaudeville performances, but it is unlikely they were in any way flattering. La Kola was billed as "The American Japanese Juggler," while Durant and Baldwin promised "music in Chinatown," including the song "You Sabe Me?" descriptions that suggest they borrowed heavily from minstrelsy's traditional depiction of the Other. ${ }^{205}$

Although major performers appeared infrequently on local vaudeville stages, during the first years of the twentieth century vaudeville performances were still very popular. A 1904 article in the San Bernardino Daily Sun noted that the Broadway and Orpheum theaters played to packed houses on the same night as the Opera House, meaning 2,500 residents were attending performances, or roughly $30 \%$ of the city's population. ${ }^{206}$ Vaudeville shows were a low cost alternative to the local Opera Houses, and rarely cost more than 25 cents for the most expensive seat with 50 cents being the highest price in the entire survey. ${ }^{207}$ This was less than half of the regularly priced 50 and 75-cent seats at the Opera Houses, and significantly less than their maximum price of $\$ 1.50$. As an emerging force in local popular culture, vaudeville's norms became so engrained that a 1906 advertisement for San Bernardino Hardware Co. parodied a vaudeville bill including a duet entitled "Outdoor Pleasures by Hoe and Rake," a monologue entitled "Cutting the Green by Sir B.B.L. Mower, and the "Serpentine Dance by R.G. Hose."208 Vaudeville's contribution to the local economy was briefly examined by the Daily Sun in an

\footnotetext{
205 Broadway Theatre Advertisement, San Bernardino Daily Sun, 5 June 1906. Broadway Theatre Advertisement, San Bernardino Daily Sun, 5 February 1905.

206 “At the Playhouses," San Bernardino Daily Sun, 9 October 1904.

207 Broadway Theatre Advertisement, San Bernardino Daily Sun, 10 July 1904. Broadway Theatre Advertisement, San Bernardino Daily Sun, 13 March 1906. Orpheum Theatre Advertisement, San Bernardino Daily Sun, 17 January 1904.

208 San Bernardino Hardware Co. Advertisement, San Bernardino Daily Sun, 23 March 1906.
} 
overview of the Broadway Theatre, which in 1906 employed 24 people paid collectively $\$ 500$ per week. $^{209}$

\section{Decline of Vaudeville}

Historians link the decline of vaudeville to the rising prominence of motion pictures and radio during the 1910s and 1920s. Alison Kibler's examination of the Keith-Albee Circuit noted that their theaters began to show the first signs of financial struggles in 1922-1923, and by 1926 economic problems were widespread throughout the circuit.210 Mere weeks after vaudeville headliner Al Jolson's influential film The Jazz Singer opened in 1927 profits at the Keith-Albee Circuit's flagship Palace Theatre in New York fell to $\$ 2,000-\$ 3,000$ per week, compared to an average of $\$ 10,000$ per week earlier in the decade. ${ }^{211}$ In 1932 , Variety reported that the Palace had been losing $\$ 5,000$ a week for over a year, and the Palace's conversion to a movie theater that November is considered the end of the golden age of vaudeville. ${ }^{212}$

Small-time vaudeville theaters in the Inland Empire had been incorporating films into their bills since their openings. A cheaper alternative to booking live performers, films could be used by new or struggling theaters to help pad out short bills and make them into a greater spectacle. The 1904 opening announcement for San Bernardino's Lyric Theater, one of several small, short lived theaters in the city, listed off four performers that could be seen for only 10 cents and concluded by noting that, "the Lyric has also been fitted with a complete moving picture apparatus

\footnotetext{
209 “Amusements," San Bernardino Daily Sun, 11 August 1906.

${ }^{210}$ Kibler, Rank Ladies, 200.

${ }^{211}$ Spitzer, The Palace, 144.

212 Spitzer, The Palace, 194.
} 
of the latest improved make and this will be turned upon the canvas tomorrow evening. Some very novel scenes will be shown, while illustrations of current events and war happenings will undoubtedly prove of much interest."213 By 1906, the Broadway Theatre had installed projectors and offered the ability to watch scenes from the San Francisco earthquake, as well as other silent films..$^{214}$

Most relevantly, standalone movie theaters began to open in the Inland Empire before 1910. In 1909, the 600-seat silent movie house called the Grand Theatre opened in Redlands, coinciding with the temporary closing of the Airdome, a local theater that had only been open for a few weeks. The article describing the opening of the Grand observed the massive size of the stage would be a good venue for live entertainment, writing, "though it could be used for the production of company plays and vaudeville specialties...it is the intention of the Amusement company to confine the entertainment to pictures and songs." ${ }^{215}$ Several short films and illustrated songs could be seen for a mere 10 cents, the same price as the cheapest ticket to a vaudeville show. ${ }^{216}$ By 1913 the rival Majestic Theater had opened and movies became so popular that the Redlands Review began running a column describing the city's film offerings in the manner it described live stage shows. ${ }^{217}$ The Wyatt Theatre, formerly the Wyatt Opera House, also embraced the revolution, extensively remodeling to support the most modern motion picture

\footnotetext{
213 “Amusements," San Bernardino Daily Sun, 1 May 1904.

214 Broadway Theatre Advertisement, San Bernardino Daily Sun, 13 May 1906. Broadway Theatre Advertisement, San Bernardino Daily Sun, 25 August 1906.

215 “Grand Theatre Opens Tonight,” Redlands Review, 29 September 1909, 5.

216 Grand Theatre Advertisement, Redlands Review, 3 October 1909, 6.

217 “At the Moving Picture Shows," Redlands Review, 21 September 1913, 3.
} 
projectors for films in color and with sound. ${ }^{218}$ In short, by 1914 the Inland Empire was at the forefront of embracing film as an alternative to vaudeville, no doubt aided by its close proximity to Hollywood and its increasing production of motion pictures, the entertainment that would ultimately end vaudeville.

\section{Conclusion}

A study of vaudeville in the Inland Empire during the early twentieth century must focus primarily on San Bernardino, the city with the most active vaudeville theaters. By studying the dynamics of vaudeville in San Bernardino, it becomes possible to observe that even small time markets showed signs of a hierarchical division of culture that has been observed by scholars like Lawrence Levine. The community demonstrated many of the typical elements of hierarchical cultural division that are often associated with its relationship to legitimate stage productions found in the local Opera House. Vaudeville theaters abided by respectability standards encouraged by the upper and middle classes to provide their productions with a sense of decency in order to attract an audience that included women and families, but also offered acts that would have been more risqué than those that appeared onstage at the high class Opera Houses. The wealthy community of Readlands's early embrace of motion pictures, an entertainment born out of vaudeville that ultimately supplanted it, fits snugly within Levine's analysis. As a result, in the Inland Empire it is possible to observe that cultural norms were shaped local elites, and that the popular culture enjoying the

\footnotetext{
218 "Kinemacolor Pictures at the Wyatt Opera House," Redlands Review, 8 October 1913, 6. "Edison's Latest Achievement. Movies That Talk, Laugh, Sing," Redlands Review, 11 October 1913, 8.
} 
largest possible audience was born from of the lower rungs of this cultural hierarchy. 
Appendix A

Opera House Performances

\begin{tabular}{|c|c|c|c|c|}
\hline \multicolumn{5}{|c|}{ San Bernardino Opera House } \\
\hline Performance & Billed Star & Genre & Date & Prices \\
\hline $\begin{array}{l}\text { Hamilton's Royal } \\
\text { Australian Minstrels }\end{array}$ & & Minstrel & 1881 & \\
\hline Under the Gaslight & & Play & $2 / 5 / 86$ & \\
\hline The Private Secretary & $\begin{array}{l}\text { Long \& Mott's } \\
\text { Comedy Co }\end{array}$ & Play & $10 / 26 / 86$ & \\
\hline Young Mrs. Winthrop & & Play & $10 / 27 / 86$ & \\
\hline $\begin{array}{l}\text { Marshall's Japanese } \\
\text { Tourists }\end{array}$ & & Acrobat & $11 / 9 / 86$ & \\
\hline Clothilde & $\begin{array}{l}\text { Miss Jeffreys- } \\
\text { Lewis }\end{array}$ & Play & $11 / 13 / 86$ & \\
\hline \multirow[t]{2}{*}{ Uncle Tom's Cabin } & LR Stockwell & Play & $11 / 16 / 86$ & $.50 / .75$ \\
\hline & John Sullivan & Athlete & $11 / 26 / 86$ & 1 \\
\hline Edmund Kean & $\begin{array}{c}\text { Francis Reinau, } \\
\text { Lizzie } \\
\text { Vigoureux }\end{array}$ & Play & $12 / 17 / 86$ & \\
\hline Hamlet & & Play & $12 / 18 / 86$ & \\
\hline The Lady of Lyons & & Play & $12 / 18 / 86$ & \\
\hline \multirow[t]{2}{*}{ Unknown } & Nellie Boyd & Play & $12 / 19 / 86$ & $.50 / .75$ \\
\hline & $\begin{array}{c}\text { Howard } \\
\text { Athenauem } \\
\text { Specialty Co }\end{array}$ & & $1 / 1 / 87$ & \\
\hline The Black Flag & & Play & $1 / 18 / 87$ & \\
\hline The Triumph of Love & & Musical & $2 / 1 / 87$ & \\
\hline Faust and Marguerite & $\begin{array}{l}\text { Lewis } \\
\text { Morrison, Celia } \\
\text { Alsberg }\end{array}$ & Play & $2 / 4 / 87$ & \\
\hline \multirow[t]{2}{*}{ Not Guilty } & & Play & $2 / 5 / 87$ & \\
\hline & $\begin{array}{l}\text { Fam Matthews } \\
\text { vs. WA Hunter }\end{array}$ & Athlete & $2 / 8 / 87$ & $.50 / .75$ \\
\hline \multirow{3}{*}{$\begin{array}{l}\text { Sight-Seeing in the } \\
\text { Emerald Isle }\end{array}$} & & Musical & $2 / 22 / 87$ & \\
\hline & $\begin{array}{l}\text { The McGibney } \\
\text { Family }\end{array}$ & Singer & $2 / 26 / 87$ & \\
\hline & $\begin{array}{c}\text { Adelaide } \\
\text { Randall Bijou } \\
\text { Opera Co }\end{array}$ & Opera & $3 / 8 / 87$ & \\
\hline JL York & & $\begin{array}{l}\text { Public } \\
\text { Speaker }\end{array}$ & $3 / 20 / 87$ & 0.25 \\
\hline & Pyke Opera Co & Musical & $3 / 28 / 87$ & $.50 / 1$ \\
\hline A Hoop of Gold & Joseph & Play & $4 / 4 / 87$ & $.50 / 1$ \\
\hline
\end{tabular}




\begin{tabular}{|c|c|c|c|c|}
\hline \multicolumn{5}{|c|}{ San Bernardino Opera House } \\
\hline Performance & Billed Star & Genre & Date & Prices \\
\hline & $\begin{array}{c}\text { Grismer, } \\
\text { Phoebe Davies }\end{array}$ & & & \\
\hline The Field of Honor & $\begin{array}{c}\text { Joseph } \\
\text { Grismer, } \\
\text { Phoebe Davies }\end{array}$ & Play & $4 / 5 / 87$ & $.50 / 1$ \\
\hline Baird's Minstrels & & Minstrel & $4 / 25 / 87$ & \\
\hline Humbug & Roland Reed & Play & $4 / 28 / 87$ & \\
\hline Cheek & Roland Reed & Play & $4 / 29 / 87$ & \\
\hline Prof. McKanlass & & Minstrel & $5 / 25 / 87$ & \\
\hline & $\begin{array}{l}\text { Perry Davis } \\
\text { Concert Co }\end{array}$ & Classical & $5 / 28 / 87$ & $.75 / 1$ \\
\hline Harbor Lights & & Play & $6 / 14 / 87$ & \\
\hline & $\begin{array}{c}\text { Oura Japanese } \\
\text { Troupe }\end{array}$ & Acrobat & 6/28/87 & \\
\hline Pearl of Savoy & Stuttz & & $7 / 4 / 87$ & \\
\hline & $\begin{array}{l}\text { Jaguarine- } \\
\text { Macallister } \\
\text { Combination }\end{array}$ & Vaudeville & $7 / 22 / 87$ & $.50 / .75$ \\
\hline Equine Paradox & & Animal & $8 / 1 / 87$ & $.25 / .50 / .75$ \\
\hline Fireman's Benefit & & & $8 / 12 / 87$ & \\
\hline The Black Flag & Edwin Thorne & Play & $8 / 26 / 87$ & $.50 / 1$ \\
\hline Unknown & Nellie Boyd & Play & $9 / 3 / 87$ & $.50 / 1$ \\
\hline Passion's Slave & Nellie Boyd & Play & $9 / 3 / 87$ & $.50 / 1$ \\
\hline & $\begin{array}{c}\text { Zerega's Royal } \\
\text { Spanish } \\
\text { Troubadors }\end{array}$ & Play & $9 / 12 / 87$ & \\
\hline Emerson's Minstrels & & Minstrel & $9 / 19 / 87$ & \\
\hline Uncle Tom's Cabin & & Play & $9 / 28 / 87$ & \\
\hline Prof. W. Anthony & & Magic & $10 / 1 / 87$ & 0.25 \\
\hline Nordeck & Frank Mayo & Play & $10 / 28 / 87$ & \\
\hline Davy Crockett & Frank Mayo & Play & $10 / 29 / 87$ & \\
\hline La Belle Russe & $\begin{array}{l}\text { Miss Jeffreys- } \\
\text { Lewis }\end{array}$ & Play & $10 / 31 / 87$ & \\
\hline $\begin{array}{l}\text { Rossner's Hungarian } \\
\text { Electric Orchestra }\end{array}$ & & Classical & $11 / 3 / 87$ & \\
\hline $\begin{array}{l}\text { Shadows of a Great } \\
\text { City }\end{array}$ & $\begin{array}{l}\text { Osbourne \& } \\
\text { Stockwell Co }\end{array}$ & Play & $11 / 8 / 87$ & \\
\hline Ranch 10 & $\begin{array}{l}\text { Osbourne \& } \\
\text { Stockwell Co }\end{array}$ & Play & $11 / 9 / 87$ & \\
\hline The Golden Giant & $\begin{array}{l}\text { Osbourne \& } \\
\text { Stockwell Co }\end{array}$ & Play & $11 / 9 / 87$ & \\
\hline Rossner's Hungarian & & Classical & $11 / 12 / 87$ & \\
\hline
\end{tabular}




\begin{tabular}{|c|c|c|c|c|}
\hline \multicolumn{5}{|c|}{ San Bernardino Opera House } \\
\hline Performance & Billed Star & Genre & Date & Prices \\
\hline Electric Orchestra & & & & \\
\hline $\begin{array}{l}\text { Alvin Joslin Comedy } \\
\text { Co }\end{array}$ & & Play & $11 / 16 / 87$ & \\
\hline Vim & Neil Burgess & Play & $11 / 17 / 87$ & \\
\hline Caught in a Corner & MB Curtis & Play & $11 / 21 / 87$ & \\
\hline Romeo and Juliet & $\begin{array}{l}\text { Margaret } \\
\text { Mather }\end{array}$ & Play & $12 / 1 / 87$ & $1 / 1.50$ \\
\hline Love and Law & Milton Nobles & Play & $12 / 7 / 87$ & \\
\hline Richards and Pringle & & Minstrel & $12 / 14 / 87$ & \\
\hline & Campanini & Opera & $12 / 23 / 87$ & $1 / 2 / 3$ \\
\hline Kate Eddy & & Magic & $12 / 25 / 87$ & \\
\hline $\begin{array}{l}\text { IW Baird's Mammoth } \\
\text { Minstrels }\end{array}$ & & Minstrel & $12 / 26 / 87$ & \\
\hline Rene & $\begin{array}{c}\text { William } \\
\text { Redmund, } \\
\text { Thomas Barry }\end{array}$ & & $1 / 2 / 88$ & \\
\hline Dan Sullivan & & $\begin{array}{l}\text { Public } \\
\text { Speaker }\end{array}$ & $1 / 3 / 88$ & $.50 / .75$ \\
\hline Held by the Enemy & $\begin{array}{l}\text { Al Hayman, } \\
\text { Lewis } \\
\text { Morrison }\end{array}$ & Play & $1 / 6 / 88$ & \\
\hline The Main Line & $\begin{array}{l}\text { Al Hayman, } \\
\text { Lewis } \\
\text { Morrison }\end{array}$ & Play & $1 / 7 / 88$ & \\
\hline She & $\begin{array}{l}\text { GP Webester, } \\
\text { William Brady }\end{array}$ & Play & $1 / 12 / 88$ & \\
\hline After Dark & $\begin{array}{l}\text { GP Webester, } \\
\text { William Brady }\end{array}$ & Play & $1 / 13 / 88$ & \\
\hline Lights O'London & $\begin{array}{l}\text { GP Webester, } \\
\text { William Brady }\end{array}$ & Play & $1 / 14 / 88$ & \\
\hline $\begin{array}{l}\text { The Count of Monte } \\
\text { Cristo }\end{array}$ & Horris Lewis & Play & $1 / 20 / 88$ & \\
\hline Uncle Tom's Cabin & Blanche Slader & Play & $1 / 25 / 88$ & \\
\hline $\begin{array}{l}\text { Woody Male } \\
\text { Quartette }\end{array}$ & & Singer & $1 / 29 / 88$ & $.50 / .75$ \\
\hline $\begin{array}{c}\text { The Streets of New } \\
\text { York }\end{array}$ & $\begin{array}{c}\text { Joseph } \\
\text { Grismer, } \\
\text { Phoebe Davies }\end{array}$ & Play & $2 / 3 / 88$ & \\
\hline Rosedale & $\begin{array}{c}\text { Joseph } \\
\text { Grismer, } \\
\text { Phoebe Davies }\end{array}$ & Play & $2 / 4 / 88$ & \\
\hline Michael Strogoff & $\begin{array}{c}\text { George } \\
\text { Wessells }\end{array}$ & Play & $2 / 10 / 88$ & \\
\hline
\end{tabular}




\begin{tabular}{|c|c|c|c|c|}
\hline \multicolumn{5}{|c|}{ San Bernardino Opera House } \\
\hline Performance & Billed Star & Genre & Date & Prices \\
\hline The White Slave & $\begin{array}{c}\text { George } \\
\text { Wessells }\end{array}$ & Play & $2 / 11 / 88$ & \\
\hline Haverly's Minstrels & & Minstrel & $2 / 14 / 88$ & \\
\hline Haverly's Minstrels & & Minstrel & $2 / 19 / 88$ & \\
\hline & $\begin{array}{l}\text { Washington } \\
\text { Irving Bishop }\end{array}$ & Magic & $3 / 5 / 88$ & \\
\hline Hermann the Great & & Magic & $9 / 21 / 88$ & \\
\hline Uncle Tom's Cabin & & Play & $1 / 12 / 89$ & \\
\hline A Night Off & & Play & $2 / 23 / 89$ & \\
\hline & Karl Gardner & & Aug 1889 & \\
\hline Romeo and Juliet & $\begin{array}{l}\text { Robert Mantell, } \\
\text { Margaret } \\
\text { Mather }\end{array}$ & Play & 1889 & \\
\hline $\begin{array}{l}\text { The Prince and the } \\
\text { Pauper }\end{array}$ & Elsie Leslie & Play & $8 / 23 / 90$ & \\
\hline In Old Kentucky & & Play & $10 / 17 / 94$ & \\
\hline $\begin{array}{c}\text { American Vadeville } \\
\text { Co }\end{array}$ & & Vaudeville & $10 / 19 / 94$ & \\
\hline $\begin{array}{l}\text { O'Neill Washington, } \\
\text { DC }\end{array}$ & Daniel Sully & Play & $11 / 3 / 94$ & $.25 / .50 / .75 / 1$ \\
\hline Killarney & Katie Emmett & Play & $11 / 13 / 94$ & \\
\hline Haverly's Minstrels & & Minstrel & $11 / 21 / 94$ & \\
\hline Charley's Aunt & & Play & $11 / 23 / 94$ & \\
\hline The Gladiator & $\begin{array}{l}\text { Dramatic } \\
\text { Company }\end{array}$ & Play & $11 / 28 / 94$ & \\
\hline $\begin{array}{l}\text { Refined Darktown } \\
\text { Lady Minstrels }\end{array}$ & & Minstrel & $4 / 28 / 99$ & \\
\hline A Night in Venice & $\begin{array}{l}\text { Wakefield- } \\
\text { Andrews } \\
\text { Opera Co }\end{array}$ & Opera & $5 / 5 / 99$ & \\
\hline & $\begin{array}{l}\text { Lambardi } \\
\text { Grand Italian } \\
\text { Opera }\end{array}$ & Opera & $5 / 27 / 99$ & \\
\hline A Midnight Ball & LR Stockwell & Play & $6 / 15 / 99$ & $.25 / .50 / .75 / 1$ \\
\hline $\begin{array}{l}\text { A Bachelor's } \\
\text { Honeymoon }\end{array}$ & & Play & 6/30/99 & $.25 / .50 / .75 / 1$ \\
\hline $\begin{array}{l}\text { The Battle of Manila } \\
\text { and Vaudeville }\end{array}$ & & $\begin{array}{c}\text { Play/ } \\
\text { Vaudeville }\end{array}$ & $7 / 4 / 99$ & $.15 / .25 / .35 / .50$ \\
\hline The Fatal Wedding & Grace Church & Play & $1 / 11 / 04$ & $.25 / .50 / .75 / 1$ \\
\hline Mahara's Minstrels & $\begin{array}{l}\text { Billy Young, } \\
\text { Gordon Collins }\end{array}$ & Minstrel & $1 / 15 / 04$ & $.25 / .50 / .75$ \\
\hline Alexander the Great & $\begin{array}{l}\text { Louis James, } \\
\text { Frederick }\end{array}$ & Play & $1 / 18 / 04$ & \\
\hline
\end{tabular}




\begin{tabular}{|c|c|c|c|c|}
\hline \multicolumn{5}{|c|}{ San Bernardino Opera House } \\
\hline Performance & Billed Star & Genre & Date & Prices \\
\hline & Warde & & & \\
\hline Richards and Pringle & & Minstrel & $1 / 25 / 04$ & \\
\hline A Night on Broadway & $\begin{array}{l}\text { Murray and } \\
\text { Mack }\end{array}$ & Musical & $1 / 30 / 04$ & \\
\hline Kidnapped & Jessie Norton & Play & $2 / 27 / 04$ & \\
\hline Pudd'n Head Wilson & James Neill & Play & $3 / 3 / 04$ & \\
\hline Maloney's Wedding & Maud Sutton & Play & $3 / 9 / 04$ & \\
\hline Human Hearts & & Play & $3 / 10 / 04$ & \\
\hline $\begin{array}{l}\text { The Merchant of } \\
\text { Venice }\end{array}$ & & Play & $3 / 21 / 04$ & \\
\hline Sag Harbor & Charles Brandt & Play & $3 / 22 / 04$ & \\
\hline Slaves of Mine & & Play & $4 / 4 / 04$ & \\
\hline Erik of Sweden & Ben Hendricks & Play & $4 / 9 / 04$ & \\
\hline Uncle Tom's Cabin & & Play & $4 / 27 / 04$ & \\
\hline $\begin{array}{l}\text { The Frisky Mrs. } \\
\text { Johnson }\end{array}$ & $\begin{array}{l}\text { Florence } \\
\text { Roberts }\end{array}$ & Play & $5 / 5 / 04$ & \\
\hline $\begin{array}{l}\text { The Drummer Boy of } \\
\text { Rappahannock }\end{array}$ & $\begin{array}{c}\text { Major } \\
\text { Hendershot }\end{array}$ & Musical & $5 / 6 / 04$ & \\
\hline Our New Minister & $\begin{array}{c}\text { Ernest } \\
\text { Hastings }\end{array}$ & Play & $6 / 1 / 04$ & $.25 / .50 / .75 / 1$ \\
\hline $\begin{array}{l}\text { Dr. Jekyl and Mr. } \\
\text { Hyde }\end{array}$ & & Play & $8 / 21 / 04$ & \\
\hline The Prince of Liars & & Play & $8 / 27 / 04$ & \\
\hline A False Friend & Frank Cooley & Play & $9 / 24 / 04$ & \\
\hline A Sleeping City & Frank Cooley & Play & $9 / 24 / 04$ & \\
\hline Sweet Clover & & Play & $10 / 21 / 04$ & \\
\hline The Burgomaster & Oscar Figoman & Play & $10 / 22 / 04$ & \\
\hline York State Folks & & Play & Oct 1904 & \\
\hline Sousa's Band & & Classical & $11 / 1 / 04$ & \\
\hline A Texas Steer & Wilt Bray & Musical & $11 / 2 / 04$ & \\
\hline Fritz and Snitz & $\begin{array}{l}\text { Mason and } \\
\text { Mason }\end{array}$ & Musical & $11 / 6 / 04$ & \\
\hline Canada & $\begin{array}{c}\text { Lester } \\
\text { Lonergan }\end{array}$ & Play & $11 / 11 / 04$ & \\
\hline West's Minstrels & Tom Mack & Minstrel & $11 / 29 / 04$ & \\
\hline Pretty Peggy & Jane Corcoran & Play & Nov 1904 & \\
\hline The Fatal Wedding & & Play & $11 / 30 / 04$ & $.10 / .25 / .50$ \\
\hline The Runaways & Arthur Dunn & Play & $12 / 1 / 04$ & $.25 / .50 / 1 / 1.50$ \\
\hline For Her Sake & Billy Marble & Play & $12 / 6 / 04$ & $.10 / .20 / .30 / .50$ \\
\hline Over Niagra Falls & & Play & $12 / 30 / 04$ & $.15 / .25 / .35 / .50$ \\
\hline $\begin{array}{l}\text { Tess of the } \\
\text { D'Urbervilles }\end{array}$ & $\begin{array}{l}\text { Florence } \\
\text { Roberts }\end{array}$ & Play & $2 / 8 / 05$ & $.25 / .50 / .75 / 1$ \\
\hline
\end{tabular}




\begin{tabular}{|c|c|c|c|c|}
\hline \multicolumn{5}{|c|}{ San Bernardino Opera House } \\
\hline Performance & Billed Star & Genre & Date & Prices \\
\hline $\begin{array}{l}\text { The Moonshiner's } \\
\text { Daughter }\end{array}$ & & Play & $2 / 20 / 05$ & $.15 / .25 / .35 / .50$ \\
\hline Creatore & & Classical & $2 / 23 / 05$ & $.25 / .50 / .75 / 1$ \\
\hline Our New Man & $\begin{array}{c}\text { Harry } \\
\text { Beresford }\end{array}$ & & $3 / 4 / 05$ & \\
\hline $\begin{array}{l}\text { London Vaudeville } \\
\text { Co }\end{array}$ & & Vaudeville & $4 / 3 / 05$ & $.10 / .15 / .25 / .35$ \\
\hline Haverly's Minstrels & & Minstrel & $\begin{array}{l}1904- \\
1905\end{array}$ & \\
\hline The Show Girl & & Musical & $\begin{array}{l}1904- \\
1905\end{array}$ & \\
\hline & Black Patti & Opera & $\begin{array}{l}1904- \\
1905\end{array}$ & \\
\hline David Harum & & Play & $\begin{array}{l}1904- \\
1905\end{array}$ & \\
\hline Friend of the Family & & Play & $\begin{array}{l}1904- \\
1905\end{array}$ & \\
\hline Ole Olson & & Play & $\begin{array}{l}1904- \\
1905\end{array}$ & \\
\hline Salambo & $\begin{array}{c}\text { Frederick } \\
\text { Warde, } \\
\text { Kathryn } \\
\text { Kidder }\end{array}$ & Play & $\begin{array}{l}1904- \\
1905\end{array}$ & \\
\hline Shore Acres & & Play & $\begin{array}{l}1904- \\
1905\end{array}$ & \\
\hline The Billionaire & & Play & $\begin{array}{l}1904- \\
1905\end{array}$ & \\
\hline The Silver Slipper & & Play & $\begin{array}{l}1904- \\
1905\end{array}$ & \\
\hline The Tenderfoot & & Play & $\begin{array}{l}1904- \\
1905\end{array}$ & \\
\hline Yon Yonson & & Play & $\begin{array}{l}1904- \\
1905\end{array}$ & \\
\hline & Joe Jefferson & Play & $\begin{array}{l}1904- \\
1905\end{array}$ & \\
\hline & Louis Morrison & Play & $\begin{array}{l}1904- \\
1905\end{array}$ & \\
\hline & $\begin{array}{c}\text { Marie } \\
\text { Wainwright }\end{array}$ & Play & $\begin{array}{l}1904- \\
1905\end{array}$ & \\
\hline & Paul Gilmore & Play & $\begin{array}{l}1904- \\
1905\end{array}$ & \\
\hline & The Ellefords & Play & $\begin{array}{l}1904- \\
1905\end{array}$ & \\
\hline
\end{tabular}




\begin{tabular}{|c|c|c|c|c|}
\hline \multicolumn{5}{|c|}{ San Bernardino Opera House } \\
\hline Performance & Billed Star & Genre & Date & Prices \\
\hline $\begin{array}{l}\text { Heatsense, The } \\
\text { Second in Oominand }\end{array}$ & $\begin{array}{c}\text { White } \\
\text { Whittlesev }\end{array}$ & & $\begin{array}{l}1904- \\
1905\end{array}$ & \\
\hline & Joe Murphy & & $\begin{array}{l}1904- \\
1905\end{array}$ & \\
\hline Stanford Glee Club & & Musical & $1 / 5 / 06$ & $.25 / .35 / .50 / .75$ \\
\hline Hooligan's Troubles & & Musical & $1 / 6 / 06$ & $.25 / .35 / .50 / .75$ \\
\hline Way Down East & & Play & $1 / 15 / 06$ & \\
\hline The Yankee Consul & Harry Short & Musical & $1 / 17 / 06$ & \\
\hline West's Minstrels & & Minstrel & $2 / 1 / 06$ & \\
\hline Around the Town & $\begin{array}{l}\text { Murray and } \\
\text { Mack }\end{array}$ & Musical & $1 / 27 / 06$ & \\
\hline Don Pasquale & Alice Nelson & Opera & $2 / 1 / 06$ & \\
\hline & $\begin{array}{l}\text { Frederick } \\
\text { Warde }\end{array}$ & Play & $2 / 3 / 06$ & \\
\hline Mary Stuart & Modjeska & Play & $2 / 10 / 06$ & \\
\hline $\begin{array}{l}\text { The Strength of the } \\
\text { Weak }\end{array}$ & $\begin{array}{l}\text { Florence } \\
\text { Roberts }\end{array}$ & Play & $2 / 12 / 06$ & \\
\hline $\begin{array}{l}\text { Jolly American } \\
\text { Tramp }\end{array}$ & & Play & $2 / 13 / 06$ & \\
\hline Ole Olson & Ben Hendricks & Play & $2 / 15 / 06$ & $.25 / .35 / .50 / .75$ \\
\hline $\begin{array}{l}\text { Sleeping Beauty and } \\
\text { the Beast }\end{array}$ & & Musical & $2 / 17 / 06$ & \\
\hline The New South & The Ellefords & Play & $2 / 19 / 06$ & $.15 / .25 / .35$ \\
\hline $\begin{array}{l}\text { Stranger in a Strange } \\
\text { Land }\end{array}$ & The Ellefords & Play & $2 / 20 / 06$ & \\
\hline $\begin{array}{l}\text { When We Were } \\
\text { Twenty-One }\end{array}$ & The Ellefords & Play & $2 / 21 / 06$ & \\
\hline A Princess of Patches & The Ellefords & Play & $2 / 22 / 06$ & \\
\hline A Poor Relation & The Ellefords & Play & $2 / 23 / 06$ & \\
\hline $\begin{array}{c}\text { Fun in a Boarding } \\
\text { School }\end{array}$ & The Ellefords & Play & $2 / 24 / 06$ & \\
\hline $\begin{array}{c}\text { Jimtown Folks } \\
\text { Abroad }\end{array}$ & The Ellefords & Play & $2 / 24 / 06$ & \\
\hline $\begin{array}{l}\text { The Princess of } \\
\text { Patches }\end{array}$ & The Ellefords & Play & $2 / 24 / 06$ & \\
\hline Shrine Minstrels & & Minstrel & $3 / 20 / 06$ & 1 \\
\hline & $\begin{array}{l}\text { Lilliputian } \\
\text { Opera Co }\end{array}$ & Opera & $3 / 21 / 06$ & \\
\hline Taming of the Shrew & $\begin{array}{l}\text { Charles } \\
\text { Hanford }\end{array}$ & Play & $3 / 24 / 06$ & \\
\hline Human Hearts & & Play & $3 / 31 / 06$ & $.25 / .35 / .50 / .75$ \\
\hline
\end{tabular}




\begin{tabular}{|c|c|c|c|c|}
\hline \multicolumn{5}{|c|}{ San Bernardino Opera House } \\
\hline Performance & Billed Star & Genre & Date & Prices \\
\hline Elk's Minstrels & & Minstrel & $4 / 23 / 06$ & 1 \\
\hline A Message from Mars & David Proctor & Play & $4 / 25 / 06$ & \\
\hline $\begin{array}{l}\text { The Merchant of } \\
\text { Venice }\end{array}$ & $\begin{array}{l}\text { Joseph } \\
\text { DeGrasse }\end{array}$ & Play & $9 / 19 / 06$ & $.25 / .50 / .75 / 1$ \\
\hline Lights of Frisco & & Play & $10 / 26 / 06$ & $.25 / .35 / .50 / .75$ \\
\hline Checkers & & Play & $10 / 29 / 06$ & \\
\hline Arizona & & Play & $10 / 31 / 06$ & \\
\hline $\begin{array}{l}\text { The Maid and the } \\
\text { Mummy }\end{array}$ & & Musical & $11 / 6 / 06$ & \\
\hline Richards and Pringle & & Minstrel & $11 / 8 / 06$ & \\
\hline Peggy From Paris & & Musical & $11 / 12 / 06$ & \\
\hline Uncle Josh Perkins & & Play & $11 / 17 / 06$ & \\
\hline Tilly Olson & & Play & $11 / 19 / 06$ & \\
\hline $\begin{array}{l}\text { The Merry Wives of } \\
\text { Windsor }\end{array}$ & Louis James & Play & $11 / 24 / 06$ & \\
\hline The Holy City & & Play & $12 / 1 / 06$ & \\
\hline Uncle Tom's Cabin & & Play & $12 / 10 / 06$ & \\
\hline Faust & $\begin{array}{c}\text { Lambardi } \\
\text { Grand Italian } \\
\text { Opera }\end{array}$ & Opera & $12 / 12 / 06$ & $.50 / .75 / 1 / 1.50 / 2$ \\
\hline $\begin{array}{l}\text { The Convict's } \\
\text { Daughter }\end{array}$ & & Play & $12 / 14 / 06$ & $.25 / .35 / .50$ \\
\hline A Cowboy's Girl & & Play & $12 / 22 / 06$ & \\
\hline As Told in the Hills & & Play & $12 / 27 / 06$ & \\
\hline Under Southern Skies & & Play & $1 / 3 / 07$ & $.25 / .35 / .50 / .75$ \\
\hline $\begin{array}{c}\text { Susan in Search of a } \\
\text { Husband }\end{array}$ & Isabel Irving & Play & $1 / 4 / 07$ & \\
\hline In Search of a Sinner & Lillian Russell & Play & $12 / 24 / 10$ & \\
\hline Richards and Pringle & & Minstrel & 1910 & \\
\hline Mikado & $\begin{array}{c}\text { National } \\
\text { Pollard Opera } \\
\text { Co }\end{array}$ & Musical & 1910 & \\
\hline Lucia & $\begin{array}{l}\text { Bevani Grand } \\
\text { Opera Co }\end{array}$ & Opera & 1910 & \\
\hline The Fairy Tale & $\begin{array}{c}\text { Madame } \\
\text { Nazimova, } \\
\text { Brandon } \\
\text { Tynan }\end{array}$ & Play & 1910 & \\
\hline The Melting Pot & $\begin{array}{c}\text { Walker } \\
\text { Whiteside }\end{array}$ & Play & 1910 & \\
\hline The Withching Hour & John Mason & Play & 1910 & \\
\hline Tales of Hoffman & Sheehan & Musical & 1911 & \\
\hline
\end{tabular}




\begin{tabular}{|c|c|c|c|c|}
\hline \multicolumn{5}{|c|}{ San Bernardino Opera House } \\
\hline Performance & Billed Star & Genre & Date & Prices \\
\hline & $\begin{array}{l}\text { English Opera } \\
\text { Co }\end{array}$ & & & \\
\hline $\begin{array}{l}\text { Alias Jimmy } \\
\text { Valentine }\end{array}$ & Frank Warner & Play & 1911 & \\
\hline Julius Caesar & $\begin{array}{l}\text { Frederick } \\
\text { Warde }\end{array}$ & Play & 1911 & \\
\hline Polly of the Circus & & Play & 1911 & \\
\hline Sis Hopkins & Rose Melville & Play & 1911 & \\
\hline The Merry Widow & $\begin{array}{l}\text { Oscar Figman, } \\
\text { Theresea Van } \\
\text { Brune }\end{array}$ & Play & 1911 & \\
\hline $\begin{array}{l}\text { The Rejuvenation of } \\
\text { Aunt Mary }\end{array}$ & May Robson & Play & 1911 & \\
\hline A Doll's House & $\begin{array}{l}\text { Madame } \\
\text { Nazimova }\end{array}$ & Play & $\begin{array}{l}1909- \\
1911\end{array}$ & \\
\hline A Lucky Star & William Collier & Play & $\begin{array}{l}1909- \\
1911\end{array}$ & \\
\hline A Woman's Way & Grace George & Play & $\begin{array}{l}1909- \\
1911\end{array}$ & \\
\hline Brewster's Millions & $\begin{array}{l}\text { George Cohan, } \\
\text { Sam Harris }\end{array}$ & Play & $\begin{array}{l}1909- \\
1911\end{array}$ & \\
\hline Cameo Kirby & Dustin Farnum & Play & $\begin{array}{l}1909- \\
1911\end{array}$ & \\
\hline Her Husband's Wife & Henry Miller & Play & $\begin{array}{l}1909- \\
1911\end{array}$ & \\
\hline The Man From Home & Henry Hall & Play & $\begin{array}{l}1909- \\
1911\end{array}$ & \\
\hline The Other Woman & Blanche Walsh & Play & $\begin{array}{l}1909- \\
1911\end{array}$ & \\
\hline The Prince of Tonight & $\begin{array}{c}\text { Henry } \\
\text { Woodruff }\end{array}$ & Play & $\begin{array}{c}1909- \\
1911\end{array}$ & \\
\hline $\begin{array}{l}\text { The Time, the Place } \\
\text { and the Girl }\end{array}$ & $\begin{array}{l}\text { Robert Pitkin, } \\
\text { Jessie Huston }\end{array}$ & Play & $\begin{array}{l}1909- \\
1911\end{array}$ & \\
\hline $\begin{array}{l}\text { The World and His } \\
\text { Wife }\end{array}$ & $\begin{array}{l}\text { William } \\
\text { Faversham }\end{array}$ & Play & $\begin{array}{l}1909- \\
1911\end{array}$ & \\
\hline The Yankee Girl & Blanche Ring & Play & $\begin{array}{l}1909- \\
1911\end{array}$ & \\
\hline Wildfire & Lillian Russell & Play & $\begin{array}{l}1909- \\
1911\end{array}$ & \\
\hline The Quaker Girl & $\begin{array}{l}\text { Mrs. Victor } \\
\text { Morley }\end{array}$ & Musical & $5 / 12 / 12$ & \\
\hline Merely Mary Ann & $\begin{array}{l}\text { Marjorie } \\
\text { Rambeau }\end{array}$ & Play & 1912 & \\
\hline
\end{tabular}




\begin{tabular}{|c|c|c|c|c|}
\hline \multicolumn{5}{|c|}{ San Bernardino Opera House } \\
\hline Performance & Billed Star & Genre & Date & Prices \\
\hline The Bohemian Girl & & Play & 1912 & \\
\hline $\begin{array}{l}\text { The Chocolate } \\
\text { Soldier }\end{array}$ & & Play & 1912 & \\
\hline The Littlest Rebel & Dustin Farnum & Play & 1912 & \\
\hline The Man From Home & William Hodge & Play & 1912 & \\
\hline Two Women & Leslie Carter & Play & 1912 & \\
\hline Maggie Pepper & Rose Stahl & Play & $4 / 17 / 13$ & \\
\hline Peter Pan & Maude Adams & Play & $4 / 19 / 13$ & \\
\hline Over the River & Eddie Foy & Play & $5 / 1 / 13$ & \\
\hline The Red Widow & $\begin{array}{l}\text { Raymond } \\
\text { Hitchcock }\end{array}$ & Play & $5 / 13 / 13$ & \\
\hline The Bird of Paradise & $\begin{array}{l}\text { Leonore Ulrich, } \\
\text { William } \\
\text { Desmond }\end{array}$ & Play & $10 / 10 / 13$ & \\
\hline $\begin{array}{c}\text { The Fascinating } \\
\text { Widow }\end{array}$ & Julian Eltinge & Play & $10 / 21 / 13$ & \\
\hline $\begin{array}{l}\text { The Chimes of } \\
\text { Normandy }\end{array}$ & $\begin{array}{c}\text { The Tivoli } \\
\text { Opera Troupe }\end{array}$ & Opera & $11 / 9 / 13$ & \\
\hline Little Women & & Play & $12 / 11 / 13$ & \\
\hline The Rainbow & Henry Miller & Play & $12 / 13 / 13$ & \\
\hline $\begin{array}{l}\text { The Lady of the } \\
\text { Camellias }\end{array}$ & $\begin{array}{c}\text { Sarah } \\
\text { Bernhardt }\end{array}$ & Musical & 1913 & \\
\hline Julius Caesar & $\begin{array}{l}\text { William } \\
\text { Faversham }\end{array}$ & Play & 1913 & \\
\hline Macbeth & Robert Mantell & Play & 1913 & \\
\hline Marc Anthony & $\begin{array}{l}\text { William } \\
\text { Faversham }\end{array}$ & Play & 1913 & \\
\hline Oliver Twist & Nat Goodwin & Play & 1913 & \\
\hline The Typhoon & $\begin{array}{c}\text { Walker } \\
\text { Whiteside }\end{array}$ & Play & 1913 & \\
\hline The Common Law & & Play & $1 / 5 / 14$ & \\
\hline The Candy Shop & $\begin{array}{l}\text { William Rock, } \\
\text { Maude Fulton }\end{array}$ & Play & $1 / 27 / 14$ & \\
\hline The Firefly & Emma Tentrini & Play & $1 / 30 / 14$ & \\
\hline Within the Law & $\begin{array}{l}\text { Margaret } \\
\text { Illington }\end{array}$ & Play & $2 / 26 / 14$ & \\
\hline Her Soul and Body & $\begin{array}{l}\text { Mrs. Douglas } \\
\text { Crane }\end{array}$ & Play & $5 / 6 / 14$ & \\
\hline Disraeli & George Arliss & Play & $11 / 24 / 14$ & \\
\hline Les Miserables & & Play & 1914 & \\
\hline Marrietta & $\begin{array}{l}\text { Evelyn Nesbit } \\
\text { Thaw }\end{array}$ & Play & 1914 & \\
\hline
\end{tabular}




\begin{tabular}{|c|c|c|c|c|}
\hline \multicolumn{5}{|c|}{ San Bernardino Opera House } \\
\hline Performance & Billed Star & Genre & Date & Prices \\
\hline Shameen Dhu & $\begin{array}{c}\text { Chauncey } \\
\text { Olcott }\end{array}$ & Play & 1914 & \\
\hline $\begin{array}{l}\text { The Tik-Tok Man of } \\
\text { Oz }\end{array}$ & & Play & 1914 & \\
\hline
\end{tabular}

\begin{tabular}{|c|c|c|c|c|}
\hline \multicolumn{5}{|c|}{ Loring Opera House, Riverside } \\
\hline Performance & Billed Star & Genre & Date & Prices \\
\hline Iolanthe & & Musical & $1 / 8 / 90$ & $1 / 1.50 / 2$ \\
\hline $\begin{array}{c}\text { Deestrict Skule No. } \\
108\end{array}$ & & Musical & $2 / 28 / 90$ & $.25 / .50$ \\
\hline Faust & Emma Juch & Opera & $1 / 1 / 91$ & \\
\hline The Ensign & & Play & $9 / 20 / 92$ & \\
\hline Julius Caesar & $\begin{array}{c}\text { Frederick } \\
\text { Warde, Louis } \\
\text { James }\end{array}$ & Play & $4 / 17 / 94$ & \\
\hline Mary Stuart & $\begin{array}{l}\text { Modjeska, Otis } \\
\text { Skinner }\end{array}$ & Play & $4 / 17 / 94$ & \\
\hline John Sousa & John Sousa & Classical & $4 / 24 / 94$ & \\
\hline The Idea & Hallen \& Hart & Musical & $6 / 13 / 94$ & $.25 / .50 / .75 / 1$ \\
\hline HMS Pinafore & & Musical & $11 / 13 / 94$ & \\
\hline Haverley's Minstrels & & Minstrel & $11 / 20 / 94$ & $.25 / .50 / .75 / 1$ \\
\hline The Gladiator & $\begin{array}{c}\text { Robert } \\
\text { Downing, } \\
\text { Eugenie Blair }\end{array}$ & Play & $12 / 5 / 94$ & \\
\hline Herr Aamold & & Opera & $12 / 26 / 94$ & \\
\hline $\begin{array}{l}\text { The Three } \\
\text { Guardsmen }\end{array}$ & $\begin{array}{l}\text { Alexander } \\
\text { Salvini }\end{array}$ & Play & $1 / 2 / 95$ & $.25 / .50 / .75 / 1 / 1.50$ \\
\hline Blind Tom & & Classical & $1 / 3 / 95$ & \\
\hline George Kennan & & $\begin{array}{l}\text { Public } \\
\text { Speaker }\end{array}$ & $1 / 29 / 95$ & \\
\hline Patience & & Opera & $2 / 8 / 95$ & \\
\hline Hazel Kirke & $\begin{array}{l}\text { Isaac Payton, } \\
\text { Mattie Keene }\end{array}$ & Play & $2 / 16 / 95$ & \\
\hline Living Whist & & Dance & $2 / 20 / 95$ & \\
\hline & & Classical & $3 / 8 / 95$ & \\
\hline Judah & $\begin{array}{c}\text { Marie } \\
\text { Burroughs }\end{array}$ & Play & $3 / 25 / 95$ & \\
\hline & & Classical & $4 / 8 / 95$ & \\
\hline Our Flat & Emily Bancker & Play & $4 / 16 / 95$ & $.25 / .50 / .75 / 1$ \\
\hline $\begin{array}{l}\text { The Girl I Left Behind } \\
\text { Me }\end{array}$ & & Play & $4 / 22 / 95$ & $.25 / .50 / .75 / 1$ \\
\hline The Gobblin' Goblin & & Musical & $5 / 3 / 95$ & \\
\hline
\end{tabular}




\begin{tabular}{|c|c|c|c|c|}
\hline \multicolumn{5}{|c|}{ Loring Opera House, Riverside } \\
\hline Performance & Billed Star & Genre & Date & Prices \\
\hline $\begin{array}{l}\text { and the Greedy } \\
\text { Gnome }\end{array}$ & & & & \\
\hline Alabama & & Play & $5 / 17 / 95$ & \\
\hline Allatoona & & Play & $5 / 30 / 95$ & \\
\hline Royal Hawaiian Band & & Classical & $7 / 5 / 95$ & \\
\hline $\begin{array}{c}\text { Miss S. Marcia Craft } \\
\text { Benefit }\end{array}$ & & & 9/27/95 & \\
\hline Dorcas & Pauline Hall & Opera & $10 / 5 / 95$ & \\
\hline The Magistrate & $\begin{array}{l}\text { LR Stockwell, } \\
\text { Rose Coghlan }\end{array}$ & Play & $10 / 12 / 95$ & \\
\hline A Fool for Luck & $\begin{array}{l}\text { Joe Carthorne, } \\
\text { Annie Buckley }\end{array}$ & Play & $11 / 14 / 95$ & \\
\hline Charley's Aunt & & Play & $11 / 19 / 95$ & \\
\hline The Parisian Princess & Rose Stillman & Play & $11 / 25 / 95$ & $.10 / .20 / .30$ \\
\hline The Clemenceau Case & Rose Stillman & Play & $11 / 27 / 95$ & \\
\hline Haverly's Minstrels & & Minstrel & $12 / 6 / 95$ & \\
\hline The Black Flag & $\begin{array}{l}\text { Jessie Norton, } \\
\text { Lorimer } \\
\text { Johnstone, WJ } \\
\text { Elleford }\end{array}$ & Play & $3 / 2 / 96$ & \\
\hline The Plunger & $\begin{array}{l}\text { Jessie Norton, } \\
\text { Lorimer } \\
\text { Johnstone, WJ } \\
\text { Elleford }\end{array}$ & Play & $3 / 3 / 96$ & \\
\hline The Corner Grocery & $\begin{array}{l}\text { Jessie Norton, } \\
\text { Lorimer } \\
\text { Johnstone, WJ } \\
\text { Elleford }\end{array}$ & Play & $3 / 4 / 96$ & \\
\hline Fritz in a Mad House & $\begin{array}{l}\text { Joseph K. } \\
\text { Emmet }\end{array}$ & Play & $4 / 6 / 96$ & \\
\hline The Embassy Ball & & Play & $9 / 14 / 96$ & $.25 / .35$ \\
\hline The Octoroon & Alice Roseland & Play & $9 / 15 / 96$ & \\
\hline Innocent Bohemia & Alice Roseland & Play & $9 / 16 / 96$ & \\
\hline Streets of New York & Alice Roseland & Play & 9/17/96 & \\
\hline A Bargain Husband & Alice Roseland & Play & 9/18/96 & \\
\hline Easy Lynne & Alice Roseland & Play & 9/19/96 & \\
\hline The Pearl of Savoy & Alice Roseland & Play & $9 / 19 / 96$ & \\
\hline $\begin{array}{c}\text { The Yaw Concert } \\
\text { Company }\end{array}$ & & Classical & $12 / 4 / 96$ & \\
\hline $\begin{array}{l}\text { Forever Devil's } \\
\text { Auction }\end{array}$ & & Dance & $1 / 2 / 97$ & \\
\hline Humanity & $\begin{array}{l}\text { Joseph } \\
\text { Grismer, }\end{array}$ & Play & $1 / 7 / 97$ & $.25 / .50 / .75 / 1$ \\
\hline
\end{tabular}




\begin{tabular}{|c|c|c|c|c|}
\hline \multicolumn{5}{|c|}{ Loring Opera House, Riverside } \\
\hline Performance & Billed Star & Genre & Date & Prices \\
\hline & Phoebe Davies & & & \\
\hline $\begin{array}{l}\text { The Man From } \\
\text { Mexico }\end{array}$ & Willie Collier & Play & $1 / 27 / 98$ & $.25 / .75 / 1 / 1.50$ \\
\hline Our Nation's History & & Play & $3 / 22 / 98$ & \\
\hline $\begin{array}{c}20 \text { Minutes Under an } \\
\text { Umbrella }\end{array}$ & & Play & $3 / 29 / 98$ & \\
\hline $\begin{array}{l}\text { The Mysterious Mr. } \\
\text { Bugle }\end{array}$ & & Play & $3 / 29 / 98$ & \\
\hline The Nancy Hanks & Marie Jansen & Musical & $5 / 10 / 98$ & \\
\hline La Mascotte & & Musical & $7 / 29 / 98$ & $.25 / .35 / .50$ \\
\hline Mikado & & Musical & $9 / 1 / 98$ & \\
\hline The Leading Man & & Play & $10 / 27 / 98$ & $.25 / .50 / .75 / 1$ \\
\hline Sowing the Winds & & Play & $11 / 15 / 98$ & \\
\hline Finnigan's Ball & Murray \& Mack & Play & $11 / 22 / 98$ & \\
\hline Hogan's Alley & & Play & $11 / 28 / 98$ & \\
\hline Mistakes Will Happen & $\begin{array}{l}\text { Charles } \\
\text { Dickson, } \\
\text { Henrietta } \\
\text { Crosman }\end{array}$ & Play & $12 / 2 / 98$ & \\
\hline A Bunch of Keys & Ada Bothner & Play & $12 / 6 / 98$ & \\
\hline The Heart of Chicago & & Play & $12 / 14 / 98$ & \\
\hline Gorton's Minstels & & Minstrel & $12 / 24 / 98$ & \\
\hline Under the Dome & & Play & $12 / 28 / 98$ & \\
\hline $\begin{array}{l}\text { The Man From } \\
\text { Mexico }\end{array}$ & Willie Collier & Play & $12 / 30 / 98$ & \\
\hline Pudd'nhead Wilson & Edwin Mayo & Play & $1 / 3 / 99$ & \\
\hline $\begin{array}{c}\text { The School for } \\
\text { Scandal }\end{array}$ & $\begin{array}{l}\text { Louis James, } \\
\text { Kathryn } \\
\text { Kidder, } \\
\text { Frederick } \\
\text { Warde }\end{array}$ & Play & $1 / 25 / 99$ & \\
\hline The Jewess & Nance O'Neil & Play & $2 / 3 / 99$ & \\
\hline Why Smith Left Home & & Play & $2 / 28 / 99$ & \\
\hline Robin Hood & The Bostonians & Musical & $3 / 8 / 99$ & \\
\hline A Night in Venice & $\begin{array}{l}\text { Johann Strauss' } \\
\text { Carnival Opera } \\
\text { Comique }\end{array}$ & Opera & $5 / 4 / 99$ & \\
\hline On and Off & & Play & $5 / 23 / 99$ & \\
\hline A Midnight Bell & LR Stockwell & Play & $6 / 13 / 99$ & \\
\hline MacBeth & $\begin{array}{l}\text { Modjeska, John } \\
\text { Kellerd }\end{array}$ & Play & $9 / 9 / 99$ & \\
\hline Hotel Topsy Turvy & Eddie Foy & Musical & $10 / 26 / 99$ & \\
\hline
\end{tabular}




\begin{tabular}{|c|c|c|c|c|}
\hline \multicolumn{5}{|c|}{ Loring Opera House, Riverside } \\
\hline Performance & Billed Star & Genre & Date & Prices \\
\hline Mlle. Fifi & Maud Granger & Play & $10 / 31 / 99$ & \\
\hline A Lady of Quality & Eugenie Blair & Play & $11 / 28 / 99$ & \\
\hline The New South & $\begin{array}{l}\text { Darrel Vinton, } \\
\text { May Nannary }\end{array}$ & Play & $12 / 4 / 99$ & \\
\hline Hamlet & $\begin{array}{l}\text { Darrel Vinton, } \\
\text { May Nannary }\end{array}$ & Play & $12 / 5 / 99$ & \\
\hline New Magdalen & $\begin{array}{l}\text { Darrel Vinton, } \\
\text { May Nannary }\end{array}$ & Play & $12 / 6 / 99$ & \\
\hline Yon Yonson & & Play & $12 / 7 / 99$ & \\
\hline Gorton's Minstels & & Minstrel & $12 / 12 / 99$ & \\
\hline My Friend From India & LR Stockwell & Play & $12 / 20 / 99$ & \\
\hline The Winter's Tale & $\begin{array}{c}\text { Louis James, } \\
\text { Kathryn } \\
\text { Kidder, Charles } \\
\text { Hanford }\end{array}$ & Play & $1 / 2 / 00$ & \\
\hline $\begin{array}{l}\text { Louise Brehany } \\
\text { Ballad and Opera } \\
\text { Concerts }\end{array}$ & & Classical & $2 / 27 / 00$ & \\
\hline Said Pasha & $\begin{array}{c}\text { Boston Lyric } \\
\text { Opera } \\
\text { Company }\end{array}$ & Musical & $3 / 7 / 00$ & \\
\hline Bohemian Girl & $\begin{array}{l}\text { Boston Lyric } \\
\text { Opera } \\
\text { Company }\end{array}$ & Musical & $3 / 8 / 00$ & \\
\hline $\begin{array}{l}\text { Have You Seen } \\
\text { Smith? }\end{array}$ & & Musical & $3 / 21 / 00$ & \\
\hline A Flag of Truce & & Play & $3 / 26 / 00$ & \\
\hline The Ensign & & Play & $3 / 27 / 00$ & \\
\hline $\begin{array}{l}\text { Little Paloma } \\
\text { Schramm }\end{array}$ & & Classical & $4 / 6 / 00$ & \\
\hline $\begin{array}{l}\text { The Gottlobs, Meyers, } \\
\text { Richard Mack, Deets } \\
\text { \& Don, Papinta, The } \\
\text { Michelsons, WC } \\
\text { Fields, Asher the } \\
\text { Great }\end{array}$ & Papinta & Vaudeville & $4 / 16 / 00$ & "Popular" \\
\hline $\begin{array}{l}\text { Brownies in } \\
\text { Fairyland }\end{array}$ & & Musical & $5 / 29 / 00$ & \\
\hline A Knotty Affair & WR Dailey & Play & $9 / 21 / 00$ & $.25 / .50 / .75$ \\
\hline $\mathrm{U}$ and I & Gus Williams & Play & $9 / 22 / 00$ & \\
\hline Othello & $\begin{array}{l}\text { Samuel Wells, } \\
\text { Glenn Will }\end{array}$ & Play & $10 / 11 / 00$ & \\
\hline That Man & Harry Lillford & Play & $10 / 25 / 00$ & \\
\hline
\end{tabular}




\begin{tabular}{|c|c|c|c|c|}
\hline \multicolumn{5}{|c|}{ Loring Opera House, Riverside } \\
\hline Performance & Billed Star & Genre & Date & Prices \\
\hline That Man & Walter Walker & Play & $10 / 25 / 00$ & \\
\hline Big Minstrel Jubilee & William West & Minstrel & $11 / 1 / 00$ & \\
\hline Uncle Tom's Cabin & & Play & $11 / 6 / 00$ & \\
\hline Hermann & & Magic & $11 / 8 / 00$ & \\
\hline Brown's In Town & & Play & $11 / 8 / 00$ & \\
\hline $\begin{array}{l}\text { Richards \& Pringle's } \\
\text { Georgia Minstrels }\end{array}$ & & Minstrel & $11 / 19 / 00$ & \\
\hline $\begin{array}{l}\text { What Did Tompkins } \\
\text { Do? }\end{array}$ & $\begin{array}{l}\text { Hary Corson } \\
\text { Clarke }\end{array}$ & Play & $11 / 20 / 00$ & \\
\hline The Ameer & Frank Daniels & Musical & $11 / 28 / 00$ & \\
\hline The Duke's Jester & $\begin{array}{c}\text { Frederick } \\
\text { Warde, ER } \\
\text { Spencer }\end{array}$ & Play & $12 / 8 / 00$ & \\
\hline $\begin{array}{c}\text { At the White Horse } \\
\text { Tavern }\end{array}$ & & Play & $12 / 10 / 00$ & \\
\hline Shenandoah & & Play & $12 / 14 / 00$ & \\
\hline Colored Aristocracy & & Minstrel & $12 / 18 / 00$ & \\
\hline Eduard Straus & & Classical & $12 / 27 / 00$ & \\
\hline Ole Olson & Ben Hendricks & Play & $12 / 29 / 00$ & \\
\hline Way Down East & & Play & $12 / 31 / 00$ & \\
\hline $\begin{array}{c}\text { Primose \& } \\
\text { Dockstader's Great } \\
\text { American Minstrels }\end{array}$ & & Minstrel & $1 / 11 / 01$ & $.25 / .50 / .75 / 1$ \\
\hline $\begin{array}{l}\text { James Wobberts, } \\
\text { Freshman }\end{array}$ & & Play & $1 / 16 / 01$ & \\
\hline $\begin{array}{l}\text { A Stranger in a } \\
\text { Strange Land }\end{array}$ & & Play & $1 / 24 / 01$ & \\
\hline Titania & & Musical & $1 / 25 / 01$ & \\
\hline Uncle Josh Spruceby & & Play & $1 / 28 / 01$ & \\
\hline Human Hearts & & Play & $1 / 31 / 01$ & \\
\hline Antoinette Trebelli & & Classical & $2 / 3 / 01$ & \\
\hline $\begin{array}{l}\text { A Midsummer Night's } \\
\text { Dream }\end{array}$ & $\begin{array}{l}\text { Luis James, } \\
\text { Kathryn } \\
\text { Kidder }\end{array}$ & Play & $2 / 19 / 01$ & \\
\hline Sousa and his Band & & Classical & $2 / 20 / 01$ & \\
\hline A Breezy Time & & Play & $2 / 25 / 01$ & \\
\hline $\begin{array}{l}\text { Wiggin \& Bowman, } \\
\text { Sid Baxter, Pearl } \\
\text { Hackman, Leondor } \\
\text { Bros., The Strollers }\end{array}$ & & Vaudeville & $3 / 9 / 01$ & \\
\hline The American Girl & & Play & $3 / 11 / 01$ & \\
\hline The Charity Ball & & Play & $3 / 12 / 01$ & \\
\hline
\end{tabular}




\begin{tabular}{|c|c|c|c|c|}
\hline \multicolumn{5}{|c|}{ Loring Opera House, Riverside } \\
\hline Performance & Billed Star & Genre & Date & Prices \\
\hline Quo Vadis & & Play & $3 / 15 / 01$ & \\
\hline Beacon Lights & & Play & $3 / 16 / 01$ & \\
\hline The Steam Laundry & & Musical & $3 / 19 / 01$ & \\
\hline The Angel of the Alley & & Play & $4 / 18 / 01$ & \\
\hline Society Vaudeville & $\begin{array}{c}\text { Riverside } \\
\text { Women's Club }\end{array}$ & Vaudeville & $5 / 24 / 01$ & \\
\hline A Texas Steer & & Play & $10 / 8 / 01$ & \\
\hline Big Minstrel Jubilee & William West & Minstrel & $10 / 11 / 01$ & \\
\hline Peaceful Valley & Frank Cooley & Play & $10 / 16 / 01$ & \\
\hline Under Two Flags & Frank Cooley & Play & $10 / 17 / 01$ & \\
\hline $\begin{array}{l}\text { A Romance of the } \\
\text { Road }\end{array}$ & Frank Cooley & Play & $10 / 18 / 01$ & \\
\hline The Butterflies & Frank Cooley & Play & $10 / 19 / 01$ & \\
\hline In Old Kentucky & & Play & $10 / 25 / 01$ & \\
\hline Secret Service & Daniel Frawley & Play & $10 / 29 / 01$ & \\
\hline Yon Yonson & & Play & $11 / 13 / 01$ & \\
\hline Shore Acres & & Play & $11 / 20 / 01$ & \\
\hline For Fair Virginia & Jessie Shirley & Play & $12 / 2 / 01$ & \\
\hline $\begin{array}{l}\text { The Sultan's } \\
\text { Daughter }\end{array}$ & Jessie Shirley & Play & $12 / 3 / 01$ & \\
\hline Trilby & Jessie Shirley & Play & $12 / 4 / 01$ & \\
\hline Nell Gwynne & Jessie Shirley & Play & $12 / 5 / 01$ & \\
\hline Camille & Jessie Shirley & Play & $12 / 6 / 01$ & \\
\hline A Young Wife & Jessie Shirley & Play & $12 / 7 / 01$ & \\
\hline $\begin{array}{l}\text { Little Lord } \\
\text { Fauntleroy }\end{array}$ & Jessie Shirley & Play & $12 / 7 / 01$ & \\
\hline Rip Van Winkle & & Play & $12 / 10 / 01$ & \\
\hline $\begin{array}{l}\text { The Cowboy and the } \\
\text { Lady }\end{array}$ & S Miller Kent & Play & $12 / 23 / 01$ & \\
\hline Big Minstrels & Hi. Henry & Minstrel & $12 / 27 / 01$ & \\
\hline $\begin{array}{c}\text { Stanford University } \\
\text { Glee and Mandolin } \\
\text { Club }\end{array}$ & & Classical & $12 / 28 / 01$ & \\
\hline SW Gillilan & & Comedy & $1 / 10 / 02$ & \\
\hline Hunting for Hawkins & & Musical & $1 / 16 / 02$ & \\
\hline $\begin{array}{c}\text { The Irish } \\
\text { Pawnbrokers }\end{array}$ & & Play & $1 / 22 / 02$ & \\
\hline Henry VIII & $\begin{array}{l}\text { Modjeska, } \\
\text { Louis James }\end{array}$ & Play & $1 / 30 / 02$ & \\
\hline The Princess Chic & & Musical & $2 / 5 / 02$ & \\
\hline $\begin{array}{l}\text { Gus Sun's American } \\
\text { Minstrels }\end{array}$ & & Minstrel & $2 / 11 / 02$ & \\
\hline
\end{tabular}




\begin{tabular}{|c|c|c|c|c|}
\hline \multicolumn{5}{|c|}{ Loring Opera House, Riverside } \\
\hline Performance & Billed Star & Genre & Date & Prices \\
\hline The Village Parson & & Play & $2 / 13 / 02$ & \\
\hline Emma Nevada & & Classical & $2 / 18 / 02$ & \\
\hline The Pride of Jennico & & Play & $2 / 22 / 02$ & \\
\hline Forget Me-Not & & Play & $2 / 28 / 02$ & \\
\hline Secret Service & & Play & $3 / 10 / 02$ & \\
\hline A Man of Mystery & & Play & $3 / 11 / 02$ & \\
\hline The World & & Play & $3 / 12 / 02$ & \\
\hline $\begin{array}{l}\text { The Girl I Left Behind } \\
\text { Me }\end{array}$ & & Play & $3 / 13 / 02$ & \\
\hline Fuast & & Play & $3 / 14 / 02$ & \\
\hline The American Girl & & Play & $3 / 14 / 02$ & \\
\hline Arizona & & Play & $3 / 19 / 02$ & \\
\hline Shooting the Chutes & Murray \& Mack & Play & $3 / 20 / 02$ & \\
\hline Way Down East & & Play & $3 / 20 / 02$ & \\
\hline Prisoner of Zenda & & Play & $3 / 25 / 02$ & \\
\hline Rupert of Hentzau & & Play & $3 / 26 / 02$ & \\
\hline Too Rich to Marry & & Play & $4 / 18 / 02$ & \\
\hline The Christian & $\begin{array}{l}\text { Edward } \\
\text { Morgan }\end{array}$ & Play & $4 / 21 / 02$ & \\
\hline Zaza & $\begin{array}{c}\text { Florence } \\
\text { Roberts }\end{array}$ & Play & $5 / 14 / 02$ & \\
\hline Virginius & $\begin{array}{l}\text { Frederick } \\
\text { Warde }\end{array}$ & Play & $6 / 19 / 02$ & \\
\hline Barbara Frietchie & $\begin{array}{l}\text { Mary Elizabeth } \\
\text { Forbes }\end{array}$ & Play & $9 / 20 / 02$ & \\
\hline Easy Lynne & $\begin{array}{l}\text { Harrington } \\
\text { Reynolds }\end{array}$ & Play & $10 / 1 / 02$ & \\
\hline $\begin{array}{l}\text { A Thoroughbred } \\
\text { Tramp }\end{array}$ & & Play & $10 / 4 / 02$ & \\
\hline Big Minstrel Jubilee & & Minstrel & $10 / 10 / 02$ & \\
\hline Fiddle Dee Dee & & Musical & $10 / 11 / 02$ & \\
\hline Sousa and his Band & & Classical & $10 / 22 / 02$ & \\
\hline Hermann & & Magic & $10 / 24 / 02$ & \\
\hline Alphonse and Gaston & & Musical & $10 / 27 / 02$ & \\
\hline Hello Bill & & Play & $10 / 29 / 02$ & \\
\hline Pickings From Puck & Willard Simms & Musical & $11 / 3 / 02$ & \\
\hline Hearts of Oak & & Play & $11 / 3 / 02$ & \\
\hline Gorton's Minstels & & Minstrel & $11 / 27 / 02$ & \\
\hline $\begin{array}{l}\text { A Voice From the } \\
\text { Wilderness }\end{array}$ & $\begin{array}{c}\text { Robert } \\
\text { Downing }\end{array}$ & Play & $11 / 29 / 02$ & \\
\hline Florodora & & Musical & $12 / 2 / 02$ & \\
\hline The Wrong Mr. & Harry & Play & $12 / 9 / 02$ & \\
\hline
\end{tabular}




\begin{tabular}{|c|c|c|c|c|}
\hline \multicolumn{5}{|c|}{ Loring Opera House, Riverside } \\
\hline Performance & Billed Star & Genre & Date & Prices \\
\hline Wright & Beresford & & & \\
\hline Shore Acres & & Play & $12 / 15 / 02$ & \\
\hline The New Robin Hood & The Bostonians & Musical & $12 / 22 / 02$ & \\
\hline Yon Yonson & & Play & $12 / 24 / 02$ & \\
\hline The Tyranny of Tears & Paul Gilmore & Play & $12 / 26 / 02$ & \\
\hline Rudolph and Adolph & $\begin{array}{l}\text { Mason \& } \\
\text { Mason }\end{array}$ & Musical & $1 / 3 / 03$ & \\
\hline A Night on Broadway & Murray \& Mack & Musical & $1 / 10 / 03$ & \\
\hline $\begin{array}{c}\text { The Man From } \\
\text { Mexico }\end{array}$ & $\begin{array}{l}\text { Leslie Morosco, } \\
\text { Leila Shaw }\end{array}$ & Play & $1 / 17 / 03$ & \\
\hline The Tempest & $\begin{array}{l}\text { Louis James, } \\
\text { Frederick } \\
\text { Warde }\end{array}$ & Play & $1 / 22 / 03$ & \\
\hline Lover's Lane & & Play & $2 / 4 / 03$ & \\
\hline Sandy Bottom & & Play & $2 / 18 / 03$ & \\
\hline A Trip to Chinatown & $\begin{array}{c}\text { Jack Campbell, } \\
\text { Harry } \\
\text { Cashman }\end{array}$ & Play & $2 / 26 / 03$ & \\
\hline The Kilties & & Dance & $3 / 20 / 03$ & \\
\hline Lord Strathmore & & Play & $3 / 26 / 03$ & \\
\hline Ole Olson & Ben Hendricks & Play & $4 / 3 / 03$ & \\
\hline $\begin{array}{l}\text { The Unwelcome Mrs. } \\
\text { Hatch }\end{array}$ & $\begin{array}{l}\text { Florence } \\
\text { Roberts }\end{array}$ & Play & $4 / 17 / 03$ & \\
\hline The Two Orphans & Kate Claxton & Play & $4 / 23 / 03$ & \\
\hline & Mme. Mantelli & Opera & $5 / 18 / 03$ & \\
\hline $\begin{array}{l}\text { Richard J. Jose } \\
\text { Minstrels }\end{array}$ & & Minstrel & $9 / 1 / 03$ & \\
\hline The Dairy Farm & & Play & $9 / 10 / 03$ & \\
\hline $\begin{array}{l}\text { A Bachelor's } \\
\text { Honeymoon }\end{array}$ & $\begin{array}{l}\text { Frank Cooley, } \\
\text { Gladys } \\
\text { Kingsbury }\end{array}$ & Play & $9 / 21 / 03$ & \\
\hline $\begin{array}{l}\text { The Mouth of the } \\
\text { Cannon }\end{array}$ & $\begin{array}{l}\text { Frank Cooley, } \\
\text { Gladys } \\
\text { Kingsbury }\end{array}$ & Play & $9 / 22 / 03$ & \\
\hline A Celestial Maiden & $\begin{array}{c}\text { Frank Cooley, } \\
\text { Gladys } \\
\text { Kingsbury }\end{array}$ & Play & $9 / 23 / 03$ & \\
\hline A Daughter of Dixie & $\begin{array}{c}\text { Frank Cooley, } \\
\text { Gladys } \\
\text { Kingsbury }\end{array}$ & Play & $9 / 25 / 03$ & \\
\hline The Sleeping City & $\begin{array}{c}\text { Frank Cooley, } \\
\text { Gladys } \\
\text { Kingsbury }\end{array}$ & Play & $9 / 26 / 03$ & \\
\hline
\end{tabular}




\begin{tabular}{|c|c|c|c|c|}
\hline \multicolumn{5}{|c|}{ Loring Opera House, Riverside } \\
\hline Performance & Billed Star & Genre & Date & Prices \\
\hline Tom Sawyer & $\begin{array}{c}\text { Frank Cooley, } \\
\text { Gladys } \\
\text { Kingsbury }\end{array}$ & Play & $9 / 26 / 03$ & \\
\hline Big Minstrel Jubilee & & Minstrel & $10 / 14 / 03$ & \\
\hline The Storks & & Musical & $10 / 29 / 03$ & \\
\hline Looking for a Wife & & Musical & $10 / 31 / 03$ & \\
\hline Hello Bill & $\begin{array}{l}\text { John Daly } \\
\text { Murphy }\end{array}$ & Play & $11 / 14 / 03$ & \\
\hline Haverly's Minstrels & Billy Van & Minstrel & $11 / 17 / 03$ & \\
\hline Way Down East & & Play & $11 / 20 / 03$ & \\
\hline $\begin{array}{c}\text { Ellery's Royal Italian } \\
\text { Band }\end{array}$ & & Classical & $11 / 24 / 03$ & \\
\hline $\begin{array}{l}\text { The Belle of New } \\
\text { York }\end{array}$ & & Musical & $12 / 3 / 03$ & \\
\hline $\begin{array}{l}\text { An American } \\
\text { Millionaire }\end{array}$ & & Musical & $12 / 4 / 03$ & \\
\hline A Gaiety Girl & & Musical & $12 / 5 / 03$ & \\
\hline HMS Pinafore & & Musical & $12 / 5 / 03$ & \\
\hline Foxy Grandpa & $\begin{array}{l}\text { Joseph Hart, } \\
\text { Carrie de Mar }\end{array}$ & Musical & $12 / 8 / 03$ & \\
\hline Are You a Mason? & & Play & $12 / 10 / 03$ & \\
\hline Spotless Town & & Musical & $12 / 14 / 03$ & \\
\hline $\begin{array}{l}\text { At the Old Cross } \\
\text { Roads }\end{array}$ & & Musical & $12 / 16 / 03$ & \\
\hline Ghosts & $\begin{array}{l}\text { Alberta } \\
\text { Gallatin }\end{array}$ & Play & $12 / 30 / 03$ & \\
\hline Yon Yonson & & Play & $12 / 31 / 03$ & \\
\hline Old Jed Prouty & & Play & $1 / 6 / 04$ & \\
\hline $\begin{array}{l}\text { Gus Sun's American } \\
\text { Minstrels }\end{array}$ & & Minstrel & $1 / 19 / 04$ & \\
\hline Alexander the Great & $\begin{array}{l}\text { Louis James, } \\
\text { Frederick } \\
\text { Warde }\end{array}$ & Play & $1 / 20 / 04$ & $.50 / .75 / 1 / 1.50$ \\
\hline A Night on Broadway & Murray \& Mack & Musical & $1 / 21 / 04$ & $.25 / .50 / .75 / 1$ \\
\hline A Flag of Truce & Ellefords & Play & $1 / 25 / 04$ & \\
\hline $\begin{array}{l}\text { The Man From } \\
\text { Mexico }\end{array}$ & & Play & $1 / 26 / 04$ & \\
\hline The Ensign & & Play & $1 / 27 / 04$ & \\
\hline Toll Gate Inn & & Play & $1 / 28 / 04$ & \\
\hline Woman's Sacrifice & & Play & $1 / 29 / 04$ & \\
\hline $\begin{array}{l}\text { Jack and the Bean } \\
\text { Stalk }\end{array}$ & & Play & $1 / 30 / 04$ & \\
\hline
\end{tabular}




\begin{tabular}{|c|c|c|c|c|}
\hline \multicolumn{5}{|c|}{ Loring Opera House, Riverside } \\
\hline Performance & Billed Star & Genre & Date & Prices \\
\hline $\begin{array}{c}\text { New York, Day by } \\
\text { Day }\end{array}$ & & Play & $1 / 30 / 04$ & \\
\hline $\begin{array}{l}\text { Circumstantial } \\
\text { Evidence }\end{array}$ & & Play & $2 / 2 / 04$ & \\
\hline Richard Carvel & $\begin{array}{l}\text { Andrew } \\
\text { Robson }\end{array}$ & Play & $2 / 11 / 04$ & \\
\hline Devil's Auction & & Musical & $2 / 26 / 04$ & \\
\hline Maloney's Wedding & & Musical & $3 / 8 / 04$ & \\
\hline Sag Harbor & & Play & $3 / 21 / 04$ & \\
\hline The Silver Slipper & Samuel Collins & Musical & $3 / 29 / 04$ & \\
\hline Erik of Sweden & Ben Hendricks & Musical & $4 / 8 / 04$ & \\
\hline $\begin{array}{l}\text { The Frisky Mrs. } \\
\text { Johnson }\end{array}$ & $\begin{array}{l}\text { Florence } \\
\text { Roberts }\end{array}$ & Play & $5 / 4 / 04$ & \\
\hline Our New Minister & & Play & $6 / 2 / 04$ & \\
\hline Sousa and his Band & & Classical & $10 / 31 / 04$ & \\
\hline Don Caesar de Bazan & $\begin{array}{c}\text { Charles } \\
\text { Hanford, Marie } \\
\text { Drofnar }\end{array}$ & Play & $3 / 23 / 05$ & \\
\hline Mary Stuart & $\begin{array}{c}\text { Helena } \\
\text { Modjeska }\end{array}$ & Play & $2 / 12 / 06$ & $.50 / .75 / 1 / 1.50 / 2$ \\
\hline Northern Lights & & Play & $2 / 21 / 06$ & \\
\hline $\begin{array}{l}\text { The Lion and the } \\
\text { Mouse }\end{array}$ & & Play & $5 / 2 / 06$ & \\
\hline A Merchant of Venice & & Play & 9/21/06 & \\
\hline Nights of Frisco & & Play & $10 / 25 / 06$ & \\
\hline $\begin{array}{c}\text { The Merry Wives of } \\
\text { Windsor }\end{array}$ & $\begin{array}{c}\text { Louis James, } \\
\text { Nellie } \\
\text { McHenry, } \\
\text { Norman } \\
\text { Hackett, Aphie } \\
\text { James }\end{array}$ & Play & $11 / 21 / 06$ & \\
\hline The Man of the Hour & & Play & $9 / 18 / 07$ & \\
\hline $\begin{array}{l}\text { The Comedy of } \\
\text { Errors }\end{array}$ & Louis James & Play & $9 / 24 / 07$ & $.50 / .75 / 1 / 1.50$ \\
\hline The Burgomaster & & Musical & $2 / 21 / 08$ & \\
\hline Glorious Betsy & $\begin{array}{c}\text { Mary } \\
\text { Mannering }\end{array}$ & Play & $2 / 26 / 08$ & \\
\hline The Great Divide & Henry Miller & Play & $6 / 24 / 08$ & \\
\hline $\begin{array}{l}\text { The Rejuvenation of } \\
\text { Aunt Mary }\end{array}$ & May Robson & Play & $8 / 7 / 08$ & \\
\hline The Squaw Man & Dustin Farnum & Play & $10 / 7 / 08$ & \\
\hline The Rivals & $\begin{array}{l}\text { Joseph Jeffries, } \\
\text { William Jeffries }\end{array}$ & Play & $11 / 20 / 08$ & \\
\hline
\end{tabular}




\begin{tabular}{|c|c|c|c|c|}
\hline \multicolumn{5}{|c|}{ Loring Opera House, Riverside } \\
\hline Performance & Billed Star & Genre & Date & Prices \\
\hline \multirow[t]{2}{*}{ Paid in Full } & & Play & $11 / 24 / 08$ & \\
\hline & $\begin{array}{c}\text { Arthur } \\
\text { Hartmann, } \\
\text { Alfred Calzin }\end{array}$ & Classical & $11 / 25 / 08$ & \\
\hline Brewster's Millions & Robert Ober & Play & $12 / 28 / 08$ & \\
\hline The Merry Widow & & Play & $8 / 5 / 09$ & \\
\hline \multirow[t]{2}{*}{ Our New Minister } & & Play & $10 / 17 / 09$ & \\
\hline & $\begin{array}{c}\text { Frieda } \\
\text { Langendorff }\end{array}$ & Classical & $10 / 29 / 09$ & \\
\hline The Music Master & David Warfield & Play & $12 / 16 / 09$ & \\
\hline Henry VIII & $\begin{array}{l}\text { Louis James, } \\
\text { Aphie James }\end{array}$ & Play & $1 / 13 / 10$ & \\
\hline The Test & Blanche Walsh & Play & $3 / 4 / 10$ & \\
\hline The Melting Pot & $\begin{array}{c}\text { Walker } \\
\text { Whiteside }\end{array}$ & Play & $10 / 20 / 10$ & \\
\hline \multirow[t]{2}{*}{ The Land of Nod } & & Musical & $11 / 16 / 10$ & \\
\hline & $\begin{array}{c}\text { The Bevani } \\
\text { Grand Opera } \\
\text { Co }\end{array}$ & Opera & $11 / 30 / 10$ & $.50 / .75 / 1 / 1.50$ \\
\hline Polly of the Circus & & Play & $1 / 4 / 11$ & \\
\hline Julius Caesar & $\begin{array}{l}\text { Frederick } \\
\text { Warde }\end{array}$ & Play & $3 / 17 / 11$ & \\
\hline The Spring Maid & Mizzi Hajos & Opera & $9 / 28 / 11$ & \\
\hline The Red Rose & & Musical & $12 / 30 / 11$ & \\
\hline The Barrier & & Play & $1 / 6 / 12$ & \\
\hline $\begin{array}{l}\text { Creatore and His } \\
\text { Band }\end{array}$ & & Classical & $3 / 11 / 12$ & \\
\hline The Faun & $\begin{array}{l}\text { William } \\
\text { Faversham, } \\
\text { Julie Opp }\end{array}$ & Play & $3 / 15 / 12$ & \\
\hline \multirow[t]{2}{*}{ Over Night } & & Play & $4 / 17 / 12$ & \\
\hline & & Vaudeville & $7 / 10 / 12$ & \\
\hline Baby Mine & $\begin{array}{l}\text { Marguerite } \\
\text { Clark, Ernest } \\
\text { Glendinning }\end{array}$ & Play & $9 / 12 / 12$ & \\
\hline $\begin{array}{l}\text { Bunty Pulls the } \\
\text { Strings }\end{array}$ & & Play & $1 / 24 / 13$ & \\
\hline $\begin{array}{c}\text { The Senator Keeps } \\
\text { House }\end{array}$ & William Crane & Play & $2 / 20 / 13$ & \\
\hline Oliver Twist & Nat Goodwin & Play & $4 / 9 / 13$ & \\
\hline The Rainbow & Henry Miller & Play & $12 / 11 / 13$ & \\
\hline Stop Thief & & Play & $12 / 19 / 13$ & \\
\hline
\end{tabular}




\begin{tabular}{|c|cc|c|c|}
\hline & \multicolumn{2}{|c|}{ Loring Opera House, Riverside } & \multirow{2}{*}{ Prices } \\
\hline Performance & Billed Star & Genre & Date & \\
\hline The Rosary & & Play & $12 / 20 / 13$ & \\
\hline Believe Me & Billy Clifford & Musical & $1 / 19 / 14$ & \\
\hline Romeo and Juliet & EH Sothern & Play & $1 / 21 / 14$ & $1 / 1.50 / 2 / 2.50$ \\
\hline The Candy Shop & $\begin{array}{c}\text { William Rock, } \\
\text { Maude Fulton }\end{array}$ & Musical & $2 / 8 / 14$ & \\
\hline The Climax & & Play & $3 / 18 / 14$ & \\
\hline The Wolf & & Play & $3 / 27 / 14$ & \\
\hline Shameen Dhu & $\begin{array}{c}\text { Chauncey } \\
\text { Olcott }\end{array}$ & Play & $5 / 7 / 14$ & \\
\hline Kitty MacKay & & Play & $11 / 9 / 14$ & \\
\hline
\end{tabular}

\begin{tabular}{|c|c|c|c|c|}
\hline \multicolumn{5}{|c|}{ Wyatt Opera House, Redlands } \\
\hline Performance & Billed Star & Genre & Date & Prices \\
\hline Sousa's Band & & Classical & $11 / 1 / 04$ & \\
\hline Twelfth Night & Ben Greet & Play & $11 / 7 / 04$ & \\
\hline $\begin{array}{l}\text { Haverly's Minstrel } \\
\text { Show }\end{array}$ & & Minstrel & $11 / 14 / 04$ & \\
\hline Pretty Peggy & & Play & $11 / 22 / 04$ & \\
\hline Fatal Wedding & & & $11 / 28 / 04$ & \\
\hline West Minstrels & & Minstrel & $11 / 30 / 04$ & \\
\hline Finnegan's Ball & & Play & $12 / 20 / 04$ & \\
\hline The Show Girl & & Musical & $12 / 23 / 04$ & \\
\hline As You Like It & & Play & $12 / 26 / 04$ & \\
\hline Kerry Gow & & & $1 / 2 / 05$ & \\
\hline & $\begin{array}{c}\text { Black Patti } \\
\text { Troubadours }\end{array}$ & Opera & $1 / 3 / 05$ & \\
\hline The Silver Slipper & & Play & $1 / 4 / 05$ & \\
\hline Looney Dreamland & & & $1 / 27 / 05$ & \\
\hline Salammbo & & Play & $1 / 30 / 05$ & \\
\hline Ole Olsen & & Play & $1 / 31 / 05$ & \\
\hline Everyman & & & $2 / 1 / 05$ & \\
\hline & $\begin{array}{c}\text { Marie } \\
\text { Wainright }\end{array}$ & Play & $2 / 3 / 05$ & \\
\hline Elks Club Vaudeville & & Vaudeville & $2 / 10 / 05$ & \\
\hline & Dolmetsch & & $2 / 15 / 05$ & \\
\hline $\begin{array}{l}\text { Tess of the } \\
\text { D'Ubervilles }\end{array}$ & & Play & $2 / 17 / 05$ & \\
\hline Faust & & Opera & $2 / 18 / 05$ & \\
\hline & $\begin{array}{l}\text { Creatore and } \\
\text { His Band }\end{array}$ & Classical & $2 / 22 / 05$ & \\
\hline Mikado & & Musical & $2 / 24 / 05$ & \\
\hline Soldiers of Fortune & & & $2 / 28 / 05$ & \\
\hline
\end{tabular}




\begin{tabular}{|c|c|c|c|c|}
\hline \multicolumn{5}{|c|}{ Wyatt Opera House, Redlands } \\
\hline Performance & Billed Star & Genre & Date & Prices \\
\hline $\begin{array}{l}\text { Stranger In a Strange } \\
\text { Land }\end{array}$ & & & $3 / 6 / 05$ & \\
\hline When We Were 21 & & & $3 / 7 / 05$ & \\
\hline $\begin{array}{l}\text { The Princess of } \\
\text { Patches }\end{array}$ & & & $3 / 8 / 05$ & \\
\hline A Poor Relation & & & $3 / 9 / 05$ & \\
\hline $\begin{array}{l}\text { Fun in Boarding } \\
\text { School }\end{array}$ & & & $3 / 10 / 05$ & \\
\hline $\begin{array}{l}\text { Jimtown Folks } \\
\text { Abroad }\end{array}$ & & & $3 / 10 / 05$ & \\
\hline Don Cesar de Bezan & & Play & $3 / 25 / 05$ & \\
\hline & $\begin{array}{l}\text { The Ellesford } \\
\text { Repertoire }\end{array}$ & Play & $4 / 3 / 05$ & \\
\hline & $\begin{array}{l}\text { Bates Stock Co. } \\
\text { Repertoire }\end{array}$ & Play & $4 / 24 / 05$ & \\
\hline $\begin{array}{l}\text { The Merchant of } \\
\text { Venice }\end{array}$ & & Play & $5 / 12 / 05$ & \\
\hline & Innes' Band & & $5 / 23 / 05$ & \\
\hline Zira & & & $5 / 24 / 05$ & \\
\hline For Her Child's Sake & & & 1905 & \\
\hline The Irish Widow & & & 1905 & \\
\hline The Yankee Consul & & Musical & $1 / 16 / 06$ & \\
\hline The Madcap Princess & & & $1 / 26 / 06$ & \\
\hline & Alice Nelson & Opera & 37282 & \\
\hline Way Down East & & Play & $1 / 30 / 06$ & \\
\hline Ole Olsen & & Play & $2 / 3 / 06$ & \\
\hline Hiawatha & & & $2 / 6 / 06$ & \\
\hline & Modieska & Play & $2 / 9 / 06$ & \\
\hline $\begin{array}{l}\text { The Strength of the } \\
\text { Weak }\end{array}$ & & Play & $2 / 13 / 06$ & \\
\hline $\begin{array}{c}\text { The Jolly American } \\
\text { Tramp }\end{array}$ & & Play & $2 / 14 / 06$ & \\
\hline Incog & & Play & $2 / 27 / 06$ & \\
\hline & $\begin{array}{l}\text { Polmatier } \\
\text { Sisters }\end{array}$ & & $3 / 12 / 06$ & \\
\hline & $\begin{array}{l}\text { Liliputian } \\
\text { Opera Co. }\end{array}$ & Opera & $3 / 19 / 06$ & \\
\hline $\begin{array}{l}\text { Arab Patrol Shrine } \\
\text { Minstrels }\end{array}$ & & Minstrel & $3 / 21 / 06$ & \\
\hline & Pugno & Classical & $3 / 22 / 06$ & \\
\hline & Kubelik & Classical & $3 / 29 / 06$ & \\
\hline Human Hearts & & Play & $3 / 30 / 06$ & \\
\hline
\end{tabular}




\begin{tabular}{|c|c|c|c|c|}
\hline \multicolumn{5}{|c|}{ Wyatt Opera House, Redlands } \\
\hline Performance & Billed Star & Genre & Date & Prices \\
\hline & Gerardy & & $4 / 11 / 06$ & \\
\hline Ermine & & & $4 / 17 / 06$ & \\
\hline As You Like It & & Play & $4 / 28 / 06$ & \\
\hline Zeke & & & $10 / 2 / 06$ & \\
\hline Mikado & & Musical & 1906 & \\
\hline Cricket on the Hearth & & & 1906 & \\
\hline The Rivals & & Play & $4 / 5 / 07$ & \\
\hline A Yankee Tourist & & & $4 / 18 / 07$ & \\
\hline Little Johnny Jones & & Musical & $10 / 21 / 07$ & \\
\hline Isle of Spice & & & $10 / 29 / 07$ & \\
\hline Mayor of Yokio & & & $11 / 15 / 07$ & \\
\hline Brown's in Town & & Play & $2 / 28 / 08$ & \\
\hline Uncle Tom's Cabin & & Play & $1 / 1 / 09$ & \\
\hline HMS Pinafore & & Musical & $1 / 29 / 09$ & \\
\hline Who's Your Friend & & & $2 / 3 / 09$ & \\
\hline Rip Van Winkle & & Play & 2/12/09 & \\
\hline Babes in Toyland & & Musical & $2 / 19 / 09$ & \\
\hline The Merry Widow & & Play & $8 / 6 / 09$ & \\
\hline Before and After & & & $8 / 17 / 09$ & \\
\hline & $\begin{array}{l}\text { International } \\
\text { Grand Opera } \\
\text { Co. }\end{array}$ & Opera & 8/18/09 & \\
\hline The Climax & & Musical & $9 / 3 / 09$ & \\
\hline Cameo Kirby & Dustin Farnum & Play & $9 / 22 / 09$ & $.50 / 2$ \\
\hline $\begin{array}{c}\text { The Time, The Place } \\
\& \text { the Girl }\end{array}$ & & Musical & $10 / 11 / 09$ & $.50 / 1.50$ \\
\hline Honeymoon Trail & & Musical & $10 / 13 / 09$ & \\
\hline A Knight for Day & & Musical & $10 / 18 / 09$ & \\
\hline Sousa's Band & & Classical & $10 / 23 / 09$ & \\
\hline $\begin{array}{l}\text { Fifty Miles from } \\
\text { Boston }\end{array}$ & George Cohan & Musical & $10 / 27 / 09$ & \\
\hline The Girl Question & & Musical & $11 / 8 / 09$ & \\
\hline The Man of the Hour & & Play & $11 / 12 / 09$ & \\
\hline The Land of Nod & & Musical & $11 / 17 / 09$ & \\
\hline Three Twins & & Musical & $12 / 9 / 09$ & $.50 / .75 / 1 / 1.50 / 2$ \\
\hline The Singing Bandits & & Musical & $12 / 10 / 09$ & \\
\hline Sapho & $\begin{array}{c}\text { Olga } \\
\text { Nethersole }\end{array}$ & Play & $12 / 25 / 09$ & $.50 / 1 / 1.50 / 2$ \\
\hline The Wolf & & Play & $12 / 27 / 09$ & \\
\hline Berkeley Glee Club & & Singer & $12 / 31 / 09$ & \\
\hline Fritz Kriesler & & Classical & $1 / 5 / 10$ & $1 / 1.50 / 2$ \\
\hline Brewster's Millions & & Play & $1 / 10 / 10$ & $.50 / 1.50$ \\
\hline
\end{tabular}




\begin{tabular}{|c|c|c|c|c|}
\hline \multicolumn{5}{|c|}{ Wyatt Opera House, Redlands } \\
\hline Performance & Billed Star & Genre & Date & Prices \\
\hline Henry VIII & Louis James & Play & $1 / 11 / 10$ & $.50 / 1.50$ \\
\hline $\begin{array}{l}45 \text { Minutes From } \\
\text { Broadway }\end{array}$ & & Musical & $1 / 14 / 10$ & $.25 / 1$ \\
\hline The Shepherd King & $\begin{array}{l}\text { Wright } \\
\text { Lorimer }\end{array}$ & Play & $1 / 18 / 10$ & $.50 / 1.50$ \\
\hline Vesta Herne & Leslie Carter & Play & $1 / 22 / 10$ & $1 / 1.50 / 2 / 2.50$ \\
\hline The Alaskan & $\begin{array}{l}\text { Richard } \\
\text { Carroll, Gus } \\
\text { Weinburg }\end{array}$ & Musical & $1 / 28 / 10$ & $.50 / 1.50$ \\
\hline The Country Squire & Lee Willard & & $2 / 9 / 10$ & $.25 / .50 / .75$ \\
\hline Babes in Toyland & Helen McLeod & Musical & $2 / 14 / 10$ & $.50 / 1.50$ \\
\hline Widow Jones & $\begin{array}{l}\text { Dorothy } \\
\text { Morton }\end{array}$ & Musical & $2 / 16 / 10$ & $.50 / 1.50$ \\
\hline St. Elmo & & Play & $2 / 18 / 10$ & $.50 / .75 / 1 / 1.50$ \\
\hline The Red Mill & & Musical & $2 / 26 / 10$ & \\
\hline The Gingerbread Man & & Musical & $2 / 28 / 10$ & \\
\hline Uncle Josh Perkins & Frank Hall & Play & $3 / 3 / 10$ & \\
\hline $\begin{array}{l}\text { Wine, Women and } \\
\text { Song }\end{array}$ & Bonita & Musical & $3 / 7 / 10$ & $.50 / 1.50$ \\
\hline Palomita & & & $4 / 11 / 10$ & \\
\hline The Prince of Tonight & & Musical & $4 / 13 / 10$ & \\
\hline The Thief & $\begin{array}{l}\text { Herbert } \\
\text { Kelcey, Effie } \\
\text { Shannon }\end{array}$ & Play & $4 / 14 / 10$ & $.50 / 1.50$ \\
\hline The Speculators & & Musical & $4 / 20 / 10$ & \\
\hline $\begin{array}{l}\text { The Rejuvenation of } \\
\text { Aunt Mary }\end{array}$ & May Robson & Play & $5 / 12 / 10$ & \\
\hline A Lucky Star & William Collier & Play & $6 / 27 / 10$ & \\
\hline The Spendthrift & Doris Mitchell & Play & $8 / 18 / 10$ & \\
\hline Rigoletto & & Opera & $12 / 1 / 10$ & \\
\hline In Search of a Sinner & & Play & $12 / 23 / 10$ & \\
\hline The Merry Widow & & Play & $2 / 21 / 11$ & \\
\hline The College Widow & & & $4 / 7 / 11$ & \\
\hline & $\begin{array}{l}\text { The Russian } \\
\text { Symphony }\end{array}$ & Classical & $4 / 24 / 11$ & \\
\hline The Yankee Girl & & Play & $4 / 25 / 11$ & \\
\hline The Toy Maker & & & $6 / 2 / 11$ & \\
\hline & $\begin{array}{l}\text { Ernestine } \\
\text { Schumann }\end{array}$ & & $2 / 2 / 12$ & \\
\hline $\begin{array}{l}\text { The Road to } \\
\text { Yesterday }\end{array}$ & & & $3 / 8 / 12$ & \\
\hline & WN Tiffany & & $5 / 1 / 12$ & \\
\hline
\end{tabular}




\begin{tabular}{|c|c|c|c|c|}
\hline \multicolumn{5}{|c|}{ Wyatt Opera House, Redlands } \\
\hline Performance & Billed Star & Genre & Date & Prices \\
\hline Little Miss Fix It & & Musical & 1912 & \\
\hline Berkeley Glee Club & & Singer & $1 / 1 / 13$ & \\
\hline The Lottery Man & & Play & $1 / 6 / 13$ & $.50 / .75 / 1$ \\
\hline Madame Butterfly & & Opera & $1 / 7 / 13$ & \\
\hline A Night Out & May Robson & Play & $1 / 10 / 13$ & \\
\hline Broadway Jones & & Play & $1 / 15 / 13$ & \\
\hline Mutt and Jeff & & Play & $1 / 20 / 13$ & \\
\hline The Rose Maid & & Musical & $1 / 30 / 13$ & \\
\hline $\begin{array}{c}\text { Trelawney of the } \\
\text { Wells }\end{array}$ & & & $2 / 12 / 13$ & \\
\hline $\begin{array}{c}\text { The Senator Keeps } \\
\text { House }\end{array}$ & William Crane & Play & $2 / 13 / 13$ & \\
\hline The Siren & Donald Brian & Musical & $3 / 18 / 13$ & \\
\hline \multirow[t]{2}{*}{ Faust } & $\begin{array}{c}\text { Sarah } \\
\text { Bernhardt }\end{array}$ & Play & $3 / 19 / 13$ & \\
\hline & Adeline Greene & Dance & $3 / 27 / 13$ & $.75 / 1 / 1.50 / 2 / 2.50$ \\
\hline Oliver Twist & Nat Goodwin & Play & $4 / 8 / 13$ & \\
\hline Maggie Pepper & Rose Stahl & Play & $4 / 18 / 13$ & \\
\hline Peter Pan & Maude Adams & Play & $4 / 21 / 13$ & \\
\hline The Red Widow & $\begin{array}{l}\text { Raymond } \\
\text { Hitchcock }\end{array}$ & Musical & $5 / 12 / 13$ & \\
\hline \multirow[t]{2}{*}{ Mary Magdalene } & Mrs. Scott & & $10 / 6 / 13$ & $.50 / 1.50$ \\
\hline & $\begin{array}{l}\text { Yvonne de } \\
\text { Treville }\end{array}$ & Opera & $3 / 2 / 14$ & \\
\hline Mice and Men & & & $4 / 3 / 14$ & \\
\hline $\begin{array}{l}\text { Chamber of } \\
\text { Commerce } \\
\text { Vaudeville }\end{array}$ & & Vaudeville & $12 / 4 / 14$ & \\
\hline Mistress Mary & & & $12 / 11 / 14$ & \\
\hline
\end{tabular}


Appendix B

Vaudeville Performances

\begin{tabular}{|c|c|c|c|c|}
\hline \multicolumn{5}{|c|}{ Unique/Broadway/State Theatre - San Bernardino } \\
\hline Performance & Billed Star & Genre & Date & Prices \\
\hline Joe Dower & & Novelty & $7 / 11 / 04$ & $.10 / .25 / .50$ \\
\hline Only Muller & & $\begin{array}{l}\text { Blackface } \\
\text { Comedian }\end{array}$ & $7 / 11 / 04$ & $.10 / .25 / .50$ \\
\hline Daisy Vernon & & Illustrated Singer & $7 / 11 / 04$ & $.10 / .25 / .50$ \\
\hline $\begin{array}{l}\text { LaCroix and } \\
\text { Campbell }\end{array}$ & & Juggler & $7 / 11 / 04$ & $.10 / .25 / .50$ \\
\hline $\begin{array}{l}\text { Pringle and } \\
\text { Kenwood }\end{array}$ & & Sketch & $7 / 11 / 04$ & $.10 / .25 / .50$ \\
\hline $\begin{array}{l}\text { Mayer and } \\
\text { Irwin }\end{array}$ & & Sketch & $7 / 11 / 04$ & $.10 / .25 / .50$ \\
\hline $\begin{array}{l}\text { The Irving } \\
\text { Trio }\end{array}$ & & Acrobat & 7/18/04 & \\
\hline Alicia Odette & & Illustrated Singer & $7 / 18 / 04$ & \\
\hline Kalacratire & & Juggler & $7 / 18 / 04$ & \\
\hline Schoenwreck & & Magic & $7 / 18 / 04$ & \\
\hline $\begin{array}{l}\text { Smith and } \\
\text { Chester }\end{array}$ & & Singer & $7 / 18 / 04$ & \\
\hline $\begin{array}{l}\text { In Country } \\
\text { School Days }\end{array}$ & Slaw and Still & Sketch & $7 / 18 / 04$ & \\
\hline Leo and Sulky & & Sketch & $7 / 18 / 04$ & \\
\hline $\begin{array}{l}\text { Howard and } \\
\text { Campbell }\end{array}$ & & Acrobat & $7 / 25 / 04$ & \\
\hline $\begin{array}{l}\text { Harry } \\
\text { Marshall }\end{array}$ & & Comedy & $7 / 25 / 04$ & \\
\hline $\begin{array}{l}\text { Aunt } \\
\text { Melinda's } \\
\text { Opportunity }\end{array}$ & $\begin{array}{l}\text { Virden and } \\
\text { Dunlap }\end{array}$ & Sketch & $7 / 25 / 04$ & \\
\hline $\begin{array}{l}\text { Champion } \\
\text { Liars }\end{array}$ & $\begin{array}{l}\text { Maude Still and } \\
\text { FH Seaward }\end{array}$ & Sketch & $7 / 25 / 04$ & \\
\hline $\begin{array}{l}\text { Charles and } \\
\text { Lulu Oro }\end{array}$ & & Comedy & $8 / 2 / 04$ & \\
\hline James Duan & & Impersonator & $8 / 2 / 04$ & \\
\hline The Kramers & & Dancer & $8 / 2 / 04$ & \\
\hline Arthur Jerome & & Illustrated Singer & $8 / 2 / 04$ & \\
\hline Lewis Berdick & & Magic & $8 / 2 / 04$ & \\
\hline Country Hotel & $\begin{array}{l}\text { Mr. and Mrs. } \\
\text { Nick Hughes }\end{array}$ & Sketch & $8 / 2 / 04$ & \\
\hline Senator Mc[?] & $\begin{array}{l}\text { Maude Still and } \\
\text { FH Seaward }\end{array}$ & Soubrette & $8 / 2 / 04$ & \\
\hline The Avalos & & Acrobat & $8 / 9 / 04$ & \\
\hline
\end{tabular}




\begin{tabular}{|c|c|c|c|c|}
\hline \multicolumn{5}{|c|}{ Unique/Broadway/State Theatre - San Bernardino } \\
\hline Performance & Billed Star & Genre & Date & Prices \\
\hline Higgins & & $\begin{array}{l}\text { Blackface } \\
\text { Comedian }\end{array}$ & $8 / 9 / 04$ & \\
\hline $\begin{array}{l}\text { A Night in a } \\
\text { Lunatic } \\
\text { Asylum }\end{array}$ & $\begin{array}{l}\text { Charles and } \\
\text { Lulu Oro }\end{array}$ & $\begin{array}{l}\text { Blackface } \\
\text { Comedian }\end{array}$ & $8 / 9 / 04$ & \\
\hline Daisy Vernon & & Illustrated Singer & $8 / 9 / 04$ & \\
\hline The Nellas & & Juggler & $8 / 9 / 04$ & \\
\hline Sue Kramer & & Dancer & $8 / 9 / 04$ & \\
\hline $\begin{array}{l}\text { The } \\
\text { Lippincotts }\end{array}$ & & Singer/Dancer & $8 / 9 / 04$ & \\
\hline $\begin{array}{l}\text { Douglas and } \\
\text { Douglas }\end{array}$ & & Acrobat & $8 / 16 / 04$ & \\
\hline $\begin{array}{l}\text { J Howard } \\
\text { Maxwell }\end{array}$ & & Comedy & $8 / 16 / 04$ & \\
\hline Daisy Vernon & & Illustrated Singer & $8 / 16 / 04$ & \\
\hline $\begin{array}{l}\text { Peres and } \\
\text { King }\end{array}$ & & Minstrel & $8 / 16 / 04$ & \\
\hline Billy Price & & Singer/Dancer & $8 / 16 / 04$ & \\
\hline $\begin{array}{l}\text { Klondike/A } \\
\text { Trip to the } \\
\text { Springs }\end{array}$ & $\begin{array}{l}\text { Charles and } \\
\text { Lulu Oro }\end{array}$ & Sketch & $8 / 16 / 04$ & \\
\hline $\begin{array}{l}\text { Label and } \\
\text { Cecil }\end{array}$ & & Sketch & $8 / 16 / 04$ & \\
\hline $\begin{array}{l}\text { Del Mae and } \\
\text { De Verne }\end{array}$ & & Acrobat & $8 / 23 / 04$ & \\
\hline $\begin{array}{l}\text { Musical } \\
\text { Walton }\end{array}$ & & Chinese Singer & $8 / 23 / 04$ & \\
\hline Daisy Vernon & & Illustrated Singer & $8 / 23 / 04$ & \\
\hline Lucille Cross & & Impersonator & $8 / 23 / 04$ & \\
\hline Raymond & & Magic & $8 / 23 / 04$ & \\
\hline $\begin{array}{l}\text { The Two } \\
\text { Burglars }\end{array}$ & $\begin{array}{l}\text { Charles and } \\
\text { Lulu Oro }\end{array}$ & Sketch & $8 / 23 / 04$ & \\
\hline $\begin{array}{l}\text { Maude Still } \\
\text { and FH } \\
\text { Seaward }\end{array}$ & & Sketch & $8 / 23 / 04$ & \\
\hline $\begin{array}{l}\text { Karl and } \\
\text { DeElmer }\end{array}$ & & Acrobat & $9 / 6 / 04$ & \\
\hline Daisy Vernon & & Illustrated Singer & $9 / 6 / 04$ & \\
\hline Rags & $\begin{array}{l}\text { Virden and } \\
\text { Dunlap }\end{array}$ & Sketch & $9 / 6 / 04$ & \\
\hline $\begin{array}{l}\text { Elmer and } \\
\text { Bartlett }\end{array}$ & & $\begin{array}{l}\text { Female } \\
\text { Impersonator }\end{array}$ & $9 / 6 / 04$ & \\
\hline Matrimonial & Charles and & Sketch & $9 / 6 / 04$ & \\
\hline
\end{tabular}




\begin{tabular}{|c|c|c|c|c|}
\hline \multicolumn{5}{|c|}{ Unique/Broadway/State Theatre - San Bernardino } \\
\hline Performance & Billed Star & Genre & Date & Prices \\
\hline Difficulties & Lulu Oro & & & \\
\hline $\begin{array}{l}\text { Maude Still } \\
\text { and FH } \\
\text { Seaward }\end{array}$ & & Sketch & $9 / 6 / 04$ & \\
\hline Grace Armond & & Soubrette & $9 / 6 / 04$ & \\
\hline $\begin{array}{l}\text { The Burger } \\
\text { Brothers }\end{array}$ & & Acrobat & 9/13/04 & \\
\hline $\begin{array}{l}\text { Hazel } \\
\text { Constenello }\end{array}$ & & Dancer & 9/13/04 & \\
\hline $\begin{array}{l}\text { The } \\
\text { Thompson } \\
\text { Sisters }\end{array}$ & & Dancer & 9/13/04 & \\
\hline Daisy Vernon & & Illustrated Singer & $9 / 13 / 04$ & \\
\hline Dorothy Vere & & Singer & $9 / 13 / 04$ & \\
\hline $\begin{array}{l}\text { Adams } \\
\text { Brothers }\end{array}$ & & Singer/Dancer & $9 / 13 / 04$ & \\
\hline $\begin{array}{l}\text { The Two } \\
\text { Sports }\end{array}$ & & Sketch & $9 / 13 / 04$ & \\
\hline $\begin{array}{l}\text { Alfred } \\
\text { Anderson }\end{array}$ & & $\begin{array}{l}\text { Female } \\
\text { Impersonator }\end{array}$ & $9 / 20 / 04$ & \\
\hline Dorothy Vere & & Illustrated Singer & $9 / 20 / 04$ & \\
\hline $\begin{array}{l}\text { Virden and } \\
\text { Dunlap }\end{array}$ & & Singer & $9 / 20 / 04$ & \\
\hline $\begin{array}{l}\text { The Silent } \\
\text { Witness }\end{array}$ & $\begin{array}{l}\text { Hall and } \\
\text { Weston }\end{array}$ & Sketch & $9 / 20 / 04$ & \\
\hline $\begin{array}{l}\text { LaClair and } \\
\text { West }\end{array}$ & & Sketch & $9 / 20 / 04$ & \\
\hline $\begin{array}{l}\text { Are You An } \\
\text { Elk }\end{array}$ & & Sketch & $9 / 27 / 04$ & \\
\hline $\begin{array}{l}\text { The Great } \\
\text { Cozora }\end{array}$ & & Equilibrist & $9 / 27 / 04$ & \\
\hline $\begin{array}{l}\text { Mabel } \\
\text { Humbert }\end{array}$ & & Singer & $9 / 27 / 04$ & \\
\hline $\begin{array}{l}\text { Fun in a China } \\
\text { Wash House }\end{array}$ & The Randolphs & Sketch & $9 / 27 / 04$ & \\
\hline $\begin{array}{l}\text { An Irish } \\
\text { Recruit }\end{array}$ & $\begin{array}{l}\text { Fairburn and } \\
\text { Caines }\end{array}$ & Sketch & $9 / 27 / 04$ & \\
\hline $\begin{array}{l}\text { The Shattuck } \\
\text { Trio }\end{array}$ & & Acrobat & $10 / 3 / 04$ & \\
\hline The Burtons & & Musician & $10 / 3 / 04$ & \\
\hline $\begin{array}{l}\text { Davey and } \\
\text { Emerson }\end{array}$ & & Comedy & $10 / 3 / 04$ & \\
\hline William & & Comedy & $10 / 3 / 04$ & \\
\hline
\end{tabular}




\begin{tabular}{|c|c|c|c|c|}
\hline \multicolumn{5}{|c|}{ Unique/Broadway/State Theatre - San Bernardino } \\
\hline Performance & Billed Star & Genre & Date & Prices \\
\hline Whalen & & & & \\
\hline $\begin{array}{l}\text { Mabel } \\
\text { Humbert }\end{array}$ & & Illustrated Singer & $10 / 3 / 04$ & \\
\hline $\begin{array}{l}\text { The Schiller } \\
\text { Brothers }\end{array}$ & & Singer & $10 / 10 / 04$ & \\
\hline $\begin{array}{l}\text { Mabel } \\
\text { Humbert }\end{array}$ & & Illustrated Singer & $10 / 10 / 04$ & \\
\hline Raymond & & Impersonator & $10 / 10 / 04$ & \\
\hline $\begin{array}{l}\text { Holmes and } \\
\text { Deane }\end{array}$ & & Novelty & $10 / 10 / 04$ & \\
\hline $\begin{array}{l}\text { Si Kidder, of } \\
\text { Boston }\end{array}$ & $\begin{array}{l}\text { Virden and } \\
\text { Dunlap }\end{array}$ & Sketch & $10 / 10 / 04$ & \\
\hline The Jamisons & & Singer/Dancer & $10 / 10 / 04$ & \\
\hline The Edwards & & Acrobat & $10 / 17 / 04$ & \\
\hline $\begin{array}{l}\text { Lue } \\
\text { Warrenton }\end{array}$ & & Monologue & $10 / 17 / 04$ & \\
\hline John Murtha & & Monologue & $10 / 17 / 04$ & \\
\hline $\begin{array}{l}\text { The Manning } \\
\text { Trio }\end{array}$ & & Comedy & $10 / 17 / 04$ & \\
\hline $\begin{array}{l}\text { Peck's Bad } \\
\text { Boy }\end{array}$ & $\begin{array}{l}\text { Virden and } \\
\text { Dunlap }\end{array}$ & Sketch & $10 / 17 / 04$ & \\
\hline $\begin{array}{l}\text { Mabel } \\
\text { Humbert }\end{array}$ & & Illustrated Singer & $10 / 17 / 04$ & \\
\hline $\begin{array}{l}\text { The } \\
\text { Massilottas }\end{array}$ & & Novelty & $10 / 17 / 04$ & \\
\hline Al Christal & & Novelty & $10 / 17 / 04$ & \\
\hline $\begin{array}{l}\text { The Wizard of } \\
\text { Wall Street }\end{array}$ & $\begin{array}{l}\text { Virden and } \\
\text { Dunlap }\end{array}$ & Sketch & $10 / 25 / 04$ & \\
\hline $\begin{array}{l}\text { Demrock } \\
\text { Brothers }\end{array}$ & & Equilibrist & $10 / 25 / 04$ & \\
\hline $\begin{array}{l}\text { Mabel } \\
\text { Humbert }\end{array}$ & & Illustrated Singer & $10 / 25 / 04$ & \\
\hline $\begin{array}{l}\text { Mr. and Mrs. } \\
\text { Searelli }\end{array}$ & & Singer & $10 / 25 / 04$ & \\
\hline CN Williams & & Juggler & $10 / 25 / 04$ & \\
\hline $\begin{array}{l}\text { Wells } \\
\text { Brothers }\end{array}$ & & Musician & $10 / 25 / 04$ & \\
\hline $\begin{array}{l}\text { Suttleiff } \\
\text { Sisters }\end{array}$ & & Soubrette & $10 / 25 / 04$ & \\
\hline $\begin{array}{l}\text { A Liar - Pro } \\
\text { Tem }\end{array}$ & Tom Elliott & Sketch & $11 / 2 / 04$ & \\
\hline $\begin{array}{l}\text { Mabel } \\
\text { Humbert }\end{array}$ & & Illustrated Singer & $11 / 2 / 04$ & \\
\hline
\end{tabular}




\begin{tabular}{|c|c|c|c|c|}
\hline \multicolumn{5}{|c|}{ Unique/Broadway/State Theatre - San Bernardino } \\
\hline Performance & Billed Star & Genre & Date & Prices \\
\hline $\begin{array}{l}\text { The } \\
\text { Campbells }\end{array}$ & & Juggler & $11 / 2 / 04$ & \\
\hline $\begin{array}{l}\text { A Modern } \\
\text { Othello }\end{array}$ & $\begin{array}{l}\text { Ellis and } \\
\text { Palerma }\end{array}$ & Sketch & $11 / 2 / 04$ & \\
\hline Margie Addis & & Soubrette & $11 / 2 / 04$ & \\
\hline The Rouselles & & Acrobat & $11 / 9 / 04$ & \\
\hline The DeLaceys & & Blackface Singer & $11 / 9 / 04$ & \\
\hline Pete Gerold & & Monologue & $11 / 9 / 04$ & \\
\hline $\begin{array}{l}\text { Mabel } \\
\text { Humbert }\end{array}$ & & Illustrated Singer & $11 / 9 / 04$ & \\
\hline $\begin{array}{l}\text { Ellis and } \\
\text { Paloma }\end{array}$ & & Singer & $11 / 9 / 04$ & \\
\hline $\begin{array}{l}\text { Wells } \\
\text { Brothers }\end{array}$ & & Musician & $11 / 9 / 04$ & \\
\hline $\begin{array}{l}\text { Boyle and } \\
\text { Lewis }\end{array}$ & & Sketch & $11 / 9 / 04$ & \\
\hline The Rouselles & & Acrobat & $11 / 16 / 04$ & \\
\hline The DeLaceys & & Comedy & $11 / 16 / 04$ & \\
\hline Margie Addis & & Singer/Dancer & $11 / 16 / 04$ & \\
\hline $\begin{array}{l}\text { Bellevue and } \\
\text { Martin }\end{array}$ & & Comedy & $11 / 16 / 04$ & \\
\hline $\begin{array}{l}\text { Mabel } \\
\text { Humbert }\end{array}$ & & Illustrated Singer & $11 / 16 / 04$ & \\
\hline $\begin{array}{l}\text { Nagle and } \\
\text { Adams }\end{array}$ & & Sketch & $11 / 16 / 04$ & \\
\hline $\begin{array}{l}\text { The } \\
\text { Aftermath }\end{array}$ & $\begin{array}{l}\text { The Broadway } \\
\text { Stock Co }\end{array}$ & Sketch & $11 / 16 / 04$ & \\
\hline $\begin{array}{l}\text { Lewis and } \\
\text { Harr }\end{array}$ & & Blackface Singer & $11 / 23 / 04$ & \\
\hline $\begin{array}{l}\text { Mabel } \\
\text { Humbert }\end{array}$ & & Illustrated Singer & $11 / 23 / 04$ & \\
\hline Bill O'Dell & & Comedian & $11 / 23 / 04$ & \\
\hline $\begin{array}{l}\text { Broadway } \\
\text { Minstrels }\end{array}$ & & Minstrel & $11 / 23 / 04$ & \\
\hline $\begin{array}{l}\text { Nagle and } \\
\text { Adams }\end{array}$ & & Sketch & $11 / 23 / 04$ & \\
\hline $\begin{array}{l}\text { Bellevue and } \\
\text { Roberts }\end{array}$ & & Sketch & $11 / 23 / 04$ & \\
\hline $\begin{array}{l}\text { Lewis and } \\
\text { Harr }\end{array}$ & & Blackface Singer & $11 / 30 / 04$ & \\
\hline Claude Kellog & & Comedy & $11 / 30 / 04$ & \\
\hline $\begin{array}{l}\text { The } \\
\text { Willagrees }\end{array}$ & & Novelty & $11 / 30 / 04$ & \\
\hline
\end{tabular}




\begin{tabular}{|c|c|c|c|c|}
\hline \multicolumn{5}{|c|}{ Unique/Broadway/State Theatre - San Bernardino } \\
\hline Performance & Billed Star & Genre & Date & Prices \\
\hline $\begin{array}{l}\text { Voltaire and } \\
\text { St. Reimo }\end{array}$ & & Singer & $11 / 30 / 04$ & \\
\hline Hale and Van & & Musician & $11 / 30 / 04$ & \\
\hline Sadie Johnson & & Singer & $11 / 30 / 04$ & \\
\hline $\begin{array}{l}\text { Married in the } \\
\text { Dark }\end{array}$ & $\begin{array}{l}\text { The Broadway } \\
\text { Farce Comedy } \\
\text { Co }\end{array}$ & Sketch & $11 / 30 / 04$ & \\
\hline Folkert & & Impersonator & $12 / 5 / 04$ & $.10 / .25 / .50$ \\
\hline $\begin{array}{l}\text { Frank } \\
\text { Appleton and } \\
\text { Perry Ed. }\end{array}$ & & $\begin{array}{l}\text { Improvisational } \\
\text { Comedian }\end{array}$ & $12 / 5 / 04$ & $.10 / .25 / .50$ \\
\hline Lloyd Spencer & & Monologue & $12 / 5 / 04$ & $.10 / .25 / .50$ \\
\hline $\begin{array}{l}\text { Voltaire and } \\
\text { St. Reimo }\end{array}$ & & Singer & $12 / 5 / 04$ & $.10 / .25 / .50$ \\
\hline Sadie Seward & & Singer & $12 / 5 / 04$ & $.10 / .25 / .50$ \\
\hline $\begin{array}{l}\text { The Doll } \\
\text { Makers' } \\
\text { Dilema }\end{array}$ & $\begin{array}{l}\text { The Four } \\
\text { Roberts }\end{array}$ & Sketch & $12 / 5 / 04$ & $.10 / .25 / .50$ \\
\hline $\begin{array}{l}\text { An Irish } \\
\text { Surprise Party }\end{array}$ & $\begin{array}{l}\text { The Broadway } \\
\text { Stock Co }\end{array}$ & Sketch & $12 / 5 / 04$ & $.10 / .25 / .50$ \\
\hline $\begin{array}{l}\text { Cohler and } \\
\text { Seymour }\end{array}$ & & Comedy & $12 / 12 / 04$ & \\
\hline Folkert & & Impersonator & $12 / 12 / 04$ & \\
\hline Sadie Seward & & Singer & $12 / 12 / 04$ & \\
\hline Al Pleau & & $\begin{array}{l}\text { Blackface } \\
\text { Comedian }\end{array}$ & $12 / 12 / 04$ & \\
\hline $\begin{array}{l}\text { The Right } \\
\text { Place, but the } \\
\text { Wrong } \\
\text { Number }\end{array}$ & $\begin{array}{l}\text { The Four } \\
\text { Roberts }\end{array}$ & Sketch & $12 / 12 / 04$ & \\
\hline $\begin{array}{l}\text { The } \\
\text { Telephone } \\
\text { Office }\end{array}$ & Bobby Boyle & Sketch & $12 / 12 / 04$ & \\
\hline $\begin{array}{l}\text { Barney } \\
\text { Williams }\end{array}$ & & Monologue & $12 / 19 / 04$ & $.10 / .25 / .50$ \\
\hline $\begin{array}{l}\text { Memphis } \\
\text { Kennedy }\end{array}$ & & Musician & $12 / 19 / 04$ & $.10 / .25 / .50$ \\
\hline Sadie Seward & & Singer & $12 / 19 / 04$ & $.10 / .25 / .50$ \\
\hline Jupiter Trio & & Singer/Dancer & $12 / 19 / 04$ & $.10 / .25 / .50$ \\
\hline The Intruder & $\begin{array}{l}\text { Kelley and } \\
\text { Massey }\end{array}$ & Sketch & $12 / 19 / 04$ & $.10 / .25 / .50$ \\
\hline $\begin{array}{l}\text { The Siege of } \\
\text { Port Arthur }\end{array}$ & $\begin{array}{l}\text { The Broadway } \\
\text { Stock Co }\end{array}$ & Sketch & $12 / 19 / 04$ & $.10 / .25 / .50$ \\
\hline
\end{tabular}




\begin{tabular}{|c|c|c|c|c|}
\hline \multicolumn{5}{|c|}{ Unique/Broadway/State Theatre - San Bernardino } \\
\hline Performance & Billed Star & Genre & Date & Prices \\
\hline JH Jackson & & Acrobat & $2 / 6 / 05$ & $.20 / .25$ \\
\hline $\begin{array}{l}\text { Durant and } \\
\text { Baldwin }\end{array}$ & & Chinese Singer & $2 / 6 / 05$ & $.20 / .25$ \\
\hline EE Lissenden & & Illustrated Singer & $2 / 6 / 05$ & $.20 / .25$ \\
\hline $\begin{array}{l}\text { Mabel } \\
\text { Melrose }\end{array}$ & & Singer & $2 / 6 / 05$ & $.20 / .25$ \\
\hline $\begin{array}{l}\text { Heim } \\
\text { Children }\end{array}$ & & Sketch & $2 / 6 / 05$ & $.20 / .25$ \\
\hline James Dervin & & Ventriliquist & $2 / 6 / 05$ & $.20 / .25$ \\
\hline Little Paul & & Acrobat & $2 / 20 / 05$ & $.15 / .20 / .25$ \\
\hline $\begin{array}{l}\text { Curtain and } \\
\text { Blossom }\end{array}$ & & Blackface Singer & $2 / 20 / 05$ & $.15 / .20 / .25$ \\
\hline A Quiet Night & Shone Family & Sketch & $2 / 20 / 05$ & $.15 / .20 / .25$ \\
\hline EE Lissenden & & Illustrated Singer & $2 / 20 / 05$ & $.15 / .20 / .25$ \\
\hline $\begin{array}{l}\text { Picket and } \\
\text { Whippler }\end{array}$ & & Dancer & $2 / 20 / 05$ & $.15 / .20 / .25$ \\
\hline $\begin{array}{l}\text { Marfield and } \\
\text { Harvey }\end{array}$ & & Dancer & $2 / 27 / 05$ & $.15 / .20 / .25$ \\
\hline James Stover & & Monologue & $2 / 27 / 05$ & $.15 / .20 / .25$ \\
\hline EE Lissenden & & Illustrated Singer & $2 / 27 / 05$ & $.15 / .20 / .25$ \\
\hline Edwin Hart & & Magic & $2 / 27 / 05$ & $.15 / .20 / .25$ \\
\hline $\begin{array}{l}\text { The Great } \\
\text { Hart Co }\end{array}$ & & Magic & $2 / 27 / 05$ & $.15 / .20 / .25$ \\
\hline $\begin{array}{l}\text { Rehu and } \\
\text { Rehu }\end{array}$ & & Sketch & $2 / 27 / 05$ & $.15 / .20 / .25$ \\
\hline Vardaman & & & $2 / 27 / 05$ & $.15 / .20 / .25$ \\
\hline George Gale & & Illustrated Singer & $3 / 10 / 05$ & $.15 / .20 / .25$ \\
\hline EE Lissenden & & Illustrated Singer & $3 / 10 / 05$ & $.15 / .20 / .25$ \\
\hline James Dervin & & Impersonator & $3 / 10 / 05$ & $.15 / .20 / .25$ \\
\hline $\begin{array}{l}\text { A Burglar's } \\
\text { Surprise }\end{array}$ & $\begin{array}{l}\text { Lavina and } \\
\text { Arlington }\end{array}$ & Sketch & $3 / 10 / 05$ & $.15 / .20 / .25$ \\
\hline $\begin{array}{l}\text { Mr. Kidder's } \\
\text { Enterprise }\end{array}$ & $\begin{array}{l}\text { Gale and } \\
\text { Wensley }\end{array}$ & Sketch & $3 / 10 / 05$ & $.15 / .20 / .25$ \\
\hline $\begin{array}{l}\text { Wallace and } \\
\text { Beech }\end{array}$ & & Acrobat & $3 / 10 / 05$ & $.15 / .20 / .25$ \\
\hline William Elton & & $\begin{array}{l}\text { Blackface } \\
\text { Comedian }\end{array}$ & $3 / 27 / 05$ & $.15 / .20 / .25$ \\
\hline Ben Salas & & $\begin{array}{l}\text { Chinese } \\
\text { Impersonator }\end{array}$ & $3 / 27 / 05$ & $.15 / .20 / .25$ \\
\hline Eva Perkins & & Illustrated Singer & $3 / 27 / 05$ & $.15 / .20 / .25$ \\
\hline $\begin{array}{l}\text { Louis } \\
\text { Lawrence }\end{array}$ & & Musician & $3 / 27 / 05$ & $.15 / .20 / .25$ \\
\hline
\end{tabular}




\begin{tabular}{|c|c|c|c|c|}
\hline \multicolumn{5}{|c|}{ Unique/Broadway/State Theatre - San Bernardino } \\
\hline Performance & Billed Star & Genre & Date & Prices \\
\hline Nonsense & The Whitesides & Sketch & $3 / 27 / 05$ & $.15 / .20 / .25$ \\
\hline $\begin{array}{l}\text { Bill and the } \\
\text { Spook }\end{array}$ & $\begin{array}{l}\text { Leona and } \\
\text { Leota }\end{array}$ & Sketch & $3 / 27 / 05$ & $.15 / .20 / .25$ \\
\hline Emma O'Neil & & Illustrated Singer & $4 / 3 / 05$ & \\
\hline Ali Zada & & Magic & $4 / 3 / 05$ & \\
\hline $\begin{array}{l}\text { Three Sisters } \\
\text { Masquereia }\end{array}$ & & Singer & $4 / 3 / 05$ & \\
\hline Niemyer Trio & & Sketch & $4 / 3 / 05$ & \\
\hline The Yard Boy & $\begin{array}{l}\text { Davis and } \\
\text { Douglas }\end{array}$ & Sketch & $4 / 3 / 05$ & \\
\hline $\begin{array}{l}\text { Louise } \\
\text { Niemyer }\end{array}$ & & Soubrette & $4 / 3 / 05$ & \\
\hline $\begin{array}{l}\text { Fay } \\
\text { Masqueria }\end{array}$ & & Soubrette & $4 / 3 / 05$ & \\
\hline Tommy Dee & & Comedy & $4 / 10 / 05$ & $.15 / .20 / .25$ \\
\hline Twisted & $\begin{array}{l}\text { Onslow and } \\
\text { Garnett }\end{array}$ & Sketch & $4 / 10 / 05$ & $.15 / .20 / .25$ \\
\hline May Kempest & & Singer & $4 / 10 / 05$ & $.15 / .20 / .25$ \\
\hline Ernest Reels & & Singer/Dancer & $4 / 10 / 05$ & $.15 / .20 / .25$ \\
\hline $\begin{array}{l}\text { The Copper } \\
\text { and the Lady }\end{array}$ & $\begin{array}{l}\text { Binney and } \\
\text { Chapman }\end{array}$ & Sketch & $4 / 10 / 05$ & $.15 / .20 / .25$ \\
\hline Mamie Costa & & Soubrette & $4 / 10 / 05$ & $.15 / .20 / .25$ \\
\hline Ben Zareli & & Comedy & $4 / 17 / 05$ & $.15 / .20 / .25$ \\
\hline $\begin{array}{l}\text { Veorg May } \\
\text { Vaeida }\end{array}$ & & Comedy & $4 / 17 / 05$ & $.15 / .20 / .25$ \\
\hline $\begin{array}{l}\text { York-Herbert } \\
\text { Trio }\end{array}$ & & Novelty & $4 / 17 / 05$ & $.15 / .20 / .25$ \\
\hline Milo Vagge & & Punching & $4 / 17 / 05$ & $.15 / .20 / .25$ \\
\hline May Kempest & & Illustrated Singer & $4 / 17 / 05$ & $.15 / .20 / .25$ \\
\hline HM Herbert & & Comedy & $4 / 17 / 05$ & $.15 / .20 / .25$ \\
\hline De Shields & & Equilibrist & $4 / 24 / 05$ & $.15 / .20 / .25$ \\
\hline May Kempest & & Illustrated Singer & $4 / 24 / 05$ & $.15 / .20 / .25$ \\
\hline $\begin{array}{l}\text { The Dutch } \\
\text { Senator }\end{array}$ & $\begin{array}{l}\text { Eugene } \\
\text { Williams }\end{array}$ & Monologue & $4 / 24 / 05$ & $.15 / .20 / .25$ \\
\hline Lizzie Welles & & Musician & $4 / 24 / 05$ & $.15 / .20 / .25$ \\
\hline $\begin{array}{l}\text { Shaw and } \\
\text { Clifton }\end{array}$ & & Singer/Dancer & $4 / 24 / 05$ & $.15 / .20 / .25$ \\
\hline $\begin{array}{l}\text { Minicahy's } \\
\text { Reception }\end{array}$ & George Rosa & Sketch & $4 / 24 / 05$ & $.15 / .20 / .25$ \\
\hline Marie Davis & & Soubrette & $4 / 24 / 05$ & $.15 / .20 / .25$ \\
\hline Eshe Brothers & & Equilibrist & $5 / 1 / 05$ & $.15 / .20 / .25$ \\
\hline Kittie Stevens & & Dancer & $5 / 1 / 05$ & $.15 / .20 / .25$ \\
\hline
\end{tabular}




\begin{tabular}{|c|c|c|c|c|}
\hline \multicolumn{5}{|c|}{ Unique/Broadway/State Theatre - San Bernardino } \\
\hline Performance & Billed Star & Genre & Date & Prices \\
\hline $\begin{array}{l}\text { Charles } \\
\text { Richards }\end{array}$ & & Illustrated Singer & $5 / 1 / 05$ & $.15 / .20 / .25$ \\
\hline $\begin{array}{l}\text { Markley and } \\
\text { Cruz }\end{array}$ & & Musician & $5 / 1 / 05$ & $.15 / .20 / .25$ \\
\hline $\begin{array}{l}\text { The Desmond } \\
\text { Sisters }\end{array}$ & & Singer/Dancer & $5 / 1 / 05$ & $.15 / .20 / .25$ \\
\hline Ella St. Vrain & & Soubrette & $5 / 1 / 05$ & $.15 / .20 / .25$ \\
\hline Serena Wolf & & Blackface Singer & $5 / 8 / 05$ & $.15 / .20 / .25$ \\
\hline Will Shaw & & $\begin{array}{l}\text { Female } \\
\text { Impersonator }\end{array}$ & $5 / 8 / 05$ & $.15 / .20 / .25$ \\
\hline $\begin{array}{l}\text { Marvelous } \\
\text { Figaro }\end{array}$ & & Juggler & $5 / 8 / 05$ & $.15 / .20 / .25$ \\
\hline $\begin{array}{l}\text { The Great } \\
\text { Wayne }\end{array}$ & & Magic & $5 / 8 / 05$ & $.15 / .20 / .25$ \\
\hline $\begin{array}{l}\text { Wilson and } \\
\text { Leicester }\end{array}$ & & Singer & $5 / 8 / 05$ & $.15 / .20 / .25$ \\
\hline $\begin{array}{l}\text { Shaw and } \\
\text { Clifton }\end{array}$ & & Singer & $5 / 8 / 05$ & $.15 / .20 / .25$ \\
\hline $\begin{array}{l}\text { The } \\
\text { Pattersons }\end{array}$ & & Acrobat & $5 / 15 / 05$ & $.15 / .20 / .25$ \\
\hline Joe Kelly & & Dancer & $5 / 15 / 05$ & $.15 / .20 / .25$ \\
\hline Eddie Leslie & & Impersonator & $5 / 15 / 05$ & $.15 / .20 / .25$ \\
\hline Mlle. Carrie & & Musician & $5 / 15 / 05$ & $.15 / .20 / .25$ \\
\hline $\begin{array}{l}\text { Varden, Perry } \\
\text { and Wilber }\end{array}$ & & Musician & $5 / 15 / 05$ & $.15 / .20 / .25$ \\
\hline Ernest Spees & & Illustrated Singer & $5 / 15 / 05$ & $.15 / .20 / .25$ \\
\hline $\begin{array}{l}\text { The Lewis } \\
\text { Children }\end{array}$ & & Acrobat & $5 / 22 / 05$ & $.15 / .20 / .25$ \\
\hline $\begin{array}{l}\text { M'Lain and } \\
\text { M'Lain }\end{array}$ & & Sketch & $5 / 22 / 05$ & $.15 / .20 / .25$ \\
\hline $\begin{array}{l}\text { Jennie } \\
\text { DeWeiss }\end{array}$ & & Musician & $5 / 22 / 05$ & $.15 / .20 / .25$ \\
\hline Pete Laird & & Singer & $5 / 22 / 05$ & $.15 / .20 / .25$ \\
\hline $\begin{array}{l}\text { Charles } \\
\text { Richards }\end{array}$ & & Singer & $5 / 22 / 05$ & $.15 / .20 / .25$ \\
\hline $\begin{array}{l}\text { The Rag Time } \\
\text { Soubrette }\end{array}$ & Zarelli & Sketch & $5 / 22 / 05$ & $.15 / .20 / .25$ \\
\hline The Waltons & & $\begin{array}{l}\text { Chinese } \\
\text { Impersonator }\end{array}$ & $1 / 3 / 06$ & $.15 / .25$ \\
\hline Frank Clayton & & Comedy & $1 / 3 / 06$ & $.15 / .25$ \\
\hline James Behan & & Comedy & $1 / 3 / 06$ & $.15 / .25$ \\
\hline Barteno & & Novelty & $1 / 3 / 06$ & $.15 / .25$ \\
\hline
\end{tabular}




\begin{tabular}{|c|c|c|c|c|}
\hline \multicolumn{5}{|c|}{ Unique/Broadway/State Theatre - San Bernardino } \\
\hline Performance & Billed Star & Genre & Date & Prices \\
\hline Jardinere & & Quick Change & $1 / 3 / 06$ & $.15 / .25$ \\
\hline John Donovan & & Comedy & $1 / 10 / 06$ & $.15 / .25$ \\
\hline $\begin{array}{l}\text { The } \\
\text { Rodriguez } \\
\text { Family }\end{array}$ & & Mexican Acrobats & $1 / 10 / 06$ & $.15 / .25$ \\
\hline The Cases & & Rifle Shooters & $1 / 10 / 06$ & $.15 / .25$ \\
\hline Vier Hill & & Singer & $1 / 10 / 06$ & $.15 / .25$ \\
\hline $\begin{array}{l}\text { Richard } \\
\text { Burton }\end{array}$ & & Singer & $1 / 10 / 06$ & $.15 / .25$ \\
\hline $\begin{array}{l}\text { Howe \& } \\
\text { Emmett }\end{array}$ & & Impersonator & $1 / 18 / 06$ & $.15 / .25$ \\
\hline $\begin{array}{l}\text { Why Brown } \\
\text { Was Blue }\end{array}$ & $\begin{array}{l}\text { The Imperial } \\
\text { Trio }\end{array}$ & Sketch & $1 / 18 / 06$ & $.15 / .25$ \\
\hline Hugh Emmett & & Musician & $1 / 18 / 06$ & $.15 / .25$ \\
\hline $\begin{array}{l}\text { The Arrival of } \\
\text { Mr. Dooley }\end{array}$ & $\begin{array}{l}\text { Howe \& } \\
\text { Edwards }\end{array}$ & Sketch & $1 / 18 / 06$ & $.15 / .25$ \\
\hline $\begin{array}{l}\text { Rizal and } \\
\text { Fatima }\end{array}$ & & Acrobat & $1 / 23 / 06$ & $.15 / .25$ \\
\hline $\begin{array}{l}\text { O'Brian from } \\
\text { Kalamazoo }\end{array}$ & $\begin{array}{l}\text { Martine \& } \\
\text { Martin }\end{array}$ & Sketch & $1 / 23 / 06$ & $.15 / .25$ \\
\hline Louis Worth & & Minstrel & $1 / 23 / 06$ & $.15 / .25$ \\
\hline $\begin{array}{l}\text { The Powers of } \\
\text { Anaesthetics }\end{array}$ & The Waltons & Sketch & $1 / 23 / 06$ & $.15 / .25$ \\
\hline $\begin{array}{l}\text { Keith and } \\
\text { Greyson }\end{array}$ & & Musician & $1 / 23 / 06$ & $.15 / .25$ \\
\hline Rapier & & Comedy & $1 / 31 / 06$ & $.15 / .25$ \\
\hline $\begin{array}{l}\text { Louis Worth } \\
\text { and Hill } \\
\text { Sisters }\end{array}$ & & Comedy & $1 / 31 / 06$ & $.15 / .25$ \\
\hline Vier Hill & & Illustrated Singer & $1 / 31 / 06$ & $.15 / .25$ \\
\hline $\begin{array}{l}\text { Sgr. And Mme. } \\
\text { Solli }\end{array}$ & & Singer & $1 / 31 / 06$ & $.15 / .25$ \\
\hline Wells \& Wells & & Novelty & $1 / 31 / 06$ & $.15 / .25$ \\
\hline Hayes Sisters & & Soubrette & $1 / 31 / 06$ & $.15 / .25$ \\
\hline A Military Ball & $\begin{array}{l}\text { Brumage \& } \\
\text { Clark }\end{array}$ & Sketch & $2 / 7 / 06$ & $.15 / .25$ \\
\hline $\begin{array}{l}\text { Josephine } \\
\text { Wallace }\end{array}$ & & Minstrel & $2 / 7 / 06$ & $.15 / .25$ \\
\hline Louis Worth & & Musician/Comedy & $2 / 7 / 06$ & $.15 / .25$ \\
\hline $\begin{array}{l}\text { Beverly \& } \\
\text { Danvers }\end{array}$ & & & $2 / 7 / 06$ & $.15 / .25$ \\
\hline $\begin{array}{l}\text { A Quaker } \\
\text { Maid }\end{array}$ & & Musical & $2 / 13 / 06$ & $.15 / .25$ \\
\hline
\end{tabular}




\begin{tabular}{|c|c|c|c|c|}
\hline \multicolumn{5}{|c|}{ Unique/Broadway/State Theatre - San Bernardino } \\
\hline Performance & Billed Star & Genre & Date & Prices \\
\hline The Hofmans & & Cycling & $2 / 20 / 06$ & $.15 / .25$ \\
\hline $\begin{array}{l}\text { Cillo the } \\
\text { Wizard }\end{array}$ & & Magic & $2 / 20 / 06$ & $.15 / .25$ \\
\hline Georgie Verdi & & Singer & $2 / 20 / 06$ & $.15 / .25$ \\
\hline $\begin{array}{l}\text { The Witch's } \\
\text { Revelry }\end{array}$ & $\begin{array}{l}\text { The Davenport } \\
\text { Bros. }\end{array}$ & Sketch & $2 / 20 / 06$ & $.15 / .25$ \\
\hline $\begin{array}{l}\text { Charles } \\
\text { Gayllor }\end{array}$ & & Acrobat & $3 / 2 / 06$ & $.15 / .25$ \\
\hline $\begin{array}{l}\text { Jimmy } \\
\text { Roberts }\end{array}$ & & Blackface Comedy & $3 / 2 / 06$ & $.15 / .25$ \\
\hline Black \& Leslie & & Comedy & $3 / 2 / 06$ & $.15 / .25$ \\
\hline Louis Worth & & Musician/Comedy & $3 / 2 / 06$ & $.15 / .25$ \\
\hline Miss Bertina & & Musician/Comedy & $3 / 2 / 06$ & $.15 / .25$ \\
\hline $\begin{array}{l}\text { Morey \& } \\
\text { Morey }\end{array}$ & & Musician/Comedy & $3 / 2 / 06$ & $.15 / .25$ \\
\hline Vier Hill & & Illustrated Singer & $3 / 2 / 06$ & $.15 / .25$ \\
\hline Paul Brachard & & Acrobat & $3 / 13 / 06$ & $.15 / .25$ \\
\hline $\begin{array}{l}\text { Douglas \& } \\
\text { M'Lain }\end{array}$ & & Comedy & $3 / 13 / 06$ & $.15 / .25$ \\
\hline Vier Hill & & Illustrated Singer & $3 / 13 / 06$ & $.15 / .25$ \\
\hline $\begin{array}{l}\text { Musical } \\
\text { Campbells }\end{array}$ & & Singer/Dancer & $3 / 13 / 06$ & $.15 / .25$ \\
\hline $\begin{array}{l}\text { Matrimonial } \\
\text { Difficulties/ } \\
\text { For Memory's } \\
\text { Sake }\end{array}$ & $\begin{array}{l}\text { Romaine \& } \\
\text { Fitch }\end{array}$ & Sketch & $3 / 13 / 06$ & $.15 / .25$ \\
\hline Clida Young & & Soubrette & $3 / 13 / 06$ & $.15 / .25$ \\
\hline $\begin{array}{l}\text { Lewis } \\
\text { Children }\end{array}$ & & Acrobat & $4 / 2 / 06$ & $.15 / .25$ \\
\hline Clida Young & & Comedy & $4 / 2 / 06$ & \\
\hline $\begin{array}{l}\text { Musical } \\
\text { Bentley }\end{array}$ & & Musician & $4 / 2 / 06$ & $.15 / .25$ \\
\hline JE Keith & & Musician & $4 / 2 / 06$ & $.15 / .25$ \\
\hline $\begin{array}{l}\text { Romaine \& } \\
\text { Fitch }\end{array}$ & & Sketch & $4 / 2 / 06$ & $.15 / .25$ \\
\hline $\begin{array}{l}\text { A Texas } \\
\text { Ranger }\end{array}$ & & Play & $4 / 9 / 06$ & $.15 / .25$ \\
\hline $\begin{array}{l}\text { A Connecticut } \\
\text { Yankee }\end{array}$ & Rudwin Co & Play & $4 / 16 / 06$ & $.15 / .25$ \\
\hline $\begin{array}{l}\text { Where is } \\
\text { Tomkins }\end{array}$ & Rudwin Co & Play & $4 / 20 / 06$ & \\
\hline Struck Oil & Rudwin Co & Play & $4 / 23 / 06$ & \\
\hline
\end{tabular}




\begin{tabular}{|c|c|c|c|c|}
\hline \multicolumn{5}{|c|}{ Unique/Broadway/State Theatre - San Bernardino } \\
\hline Performance & Billed Star & Genre & Date & Prices \\
\hline $\begin{array}{l}\text { Married By } \\
\text { Mistake }\end{array}$ & Rudwin Co & Play & $5 / 6 / 06$ & \\
\hline $\begin{array}{l}\text { La Rue } \\
\text { Brothers }\end{array}$ & & Acrobat & $5 / 7 / 06$ & $.15 / .25$ \\
\hline $\begin{array}{l}\text { James } \\
\text { Diamond }\end{array}$ & & Dancer & $5 / 7 / 06$ & $.15 / .25$ \\
\hline Monroe & & Musician & $5 / 7 / 06$ & $.15 / .25$ \\
\hline Hill Sisters & & Singer/Dancer & $5 / 7 / 06$ & $.15 / .25$ \\
\hline $\begin{array}{l}\text { Fitch \& } \\
\text { Romaine }\end{array}$ & & Sketch & $5 / 7 / 06$ & $.15 / .25$ \\
\hline $\begin{array}{l}\text { George } \\
\text { Delmas }\end{array}$ & & Acrobat & $5 / 24 / 06$ & $.15 / .25$ \\
\hline La Mar & & Comedy & $5 / 24 / 06$ & $.15 / .25$ \\
\hline Royal Sisters & & Dancer & $5 / 24 / 06$ & $.15 / .25$ \\
\hline The Patricolas & & Musician/Comedy & $5 / 24 / 06$ & $.15 / .25$ \\
\hline Dale \& Carrey & & & $5 / 24 / 06$ & $.15 / .25$ \\
\hline $\begin{array}{l}\text { The Daffy } \\
\text { Dame }\end{array}$ & Paul La Drew & Sketch & $5 / 29 / 06$ & $.15 / .25$ \\
\hline $\begin{array}{l}\text { Isabelle } \\
\text { Patricola }\end{array}$ & & Musician & $5 / 29 / 06$ & $.15 / .25$ \\
\hline The Patricolas & & Musician/Comedy & $5 / 29 / 06$ & $.15 / .25$ \\
\hline Vier Hill & & Illustrated Singer & $5 / 29 / 06$ & $.15 / .25$ \\
\hline Daye \& Knight & & Sketch & $5 / 29 / 06$ & $.15 / .25$ \\
\hline $\begin{array}{l}\text { The Widow's } \\
\text { Courtship }\end{array}$ & $\begin{array}{l}\text { Rossley \& } \\
\text { Rostelle }\end{array}$ & Sketch & $5 / 29 / 06$ & $.15 / .25$ \\
\hline $\begin{array}{l}\text { The Great } \\
\text { Garza }\end{array}$ & & Equilibrist & $6 / 5 / 06$ & $.15 / .25$ \\
\hline La Kola & & Japanese Juggler & $6 / 5 / 06$ & $.15 / .25$ \\
\hline Charlotte Hill & & Musician & $6 / 5 / 06$ & $.15 / .25$ \\
\hline Vier Hill & & Illustrated Singer & $6 / 5 / 06$ & $.15 / .25$ \\
\hline $\begin{array}{l}\text { McHendry, } \\
\text { Wilber \& } \\
\text { McHendry }\end{array}$ & & Singer/Dancer & $6 / 5 / 06$ & $.15 / .25$ \\
\hline Dale \& Carreg & & Sketch & $6 / 5 / 06$ & $.15 / .25$ \\
\hline $\begin{array}{l}\text { The Great } \\
\text { Menlo }\end{array}$ & & Magic & $6 / 12 / 06$ & $.15 / .25$ \\
\hline Nellie Hill & & Illustrated Singer & $6 / 12 / 06$ & $.15 / .25$ \\
\hline $\begin{array}{l}\text { Halden \& } \\
\text { Hayden }\end{array}$ & & Singer & $6 / 12 / 06$ & $.15 / .25$ \\
\hline Marie Laurens & & Singer & $6 / 12 / 06$ & $.15 / .25$ \\
\hline $\begin{array}{l}\text { The } \\
\text { Serenaders }\end{array}$ & $\begin{array}{l}\text { The Three } \\
\text { Daniels }\end{array}$ & Sketch & $6 / 12 / 06$ & $.15 / .25$ \\
\hline
\end{tabular}




\begin{tabular}{|c|c|c|c|c|}
\hline \multicolumn{5}{|c|}{ Unique/Broadway/State Theatre - San Bernardino } \\
\hline Performance & Billed Star & Genre & Date & Prices \\
\hline $\begin{array}{l}\text { Jimmy } \\
\text { Roberts }\end{array}$ & & Comedy & $6 / 19 / 06$ & \\
\hline Equillo & & Equilibrist & $6 / 19 / 06$ & \\
\hline Vier Hill & & Illustrated Singer & $6 / 19 / 06$ & \\
\hline Marie Laurens & & Singer & $6 / 19 / 06$ & \\
\hline $\begin{array}{l}\text { Hill, Yiung } \\
\text { and Hill }\end{array}$ & & Singer/Dancer & $6 / 19 / 06$ & \\
\hline $\begin{array}{l}\text { Mother, Pig a } \\
\text { Rose on Me }\end{array}$ & Jim Diamond & Sketch & $6 / 19 / 06$ & \\
\hline $\begin{array}{l}\text { Romaine \& } \\
\text { Fitch }\end{array}$ & & Sketch & $6 / 19 / 06$ & \\
\hline Pete Fearr & & Comedy & $6 / 26 / 06$ & \\
\hline $\begin{array}{l}\text { Fields \& } \\
\text { Hanson }\end{array}$ & & Comedy & $6 / 26 / 06$ & \\
\hline Vier Hill & & Illustrated Singer & $6 / 26 / 06$ & \\
\hline RL Henderson & & Musician & $6 / 26 / 06$ & \\
\hline Clida Young & & Musician & $6 / 26 / 06$ & \\
\hline Vera Ransdall & & Soubrette & $6 / 26 / 06$ & \\
\hline $\begin{array}{l}\text { Gerald \& } \\
\text { Clayton }\end{array}$ & & Sketch & $6 / 26 / 06$ & \\
\hline $\begin{array}{l}\text { Wicked } \\
\text { London }\end{array}$ & $\begin{array}{l}\text { Empire Theatre } \\
\text { Co }\end{array}$ & Play & $7 / 9 / 06$ & $.15 / .25 / .35$ \\
\hline The Sheriff & $\begin{array}{l}\text { Empire Theatre } \\
\text { Co }\end{array}$ & Play & $7 / 20 / 06$ & \\
\hline $\begin{array}{l}\text { Marching } \\
\text { Thro Georgia }\end{array}$ & $\begin{array}{l}\text { Empire Theatre } \\
\text { Co }\end{array}$ & Play & $7 / 24 / 06$ & \\
\hline $\begin{array}{l}\text { A Golden } \\
\text { Giant }\end{array}$ & $\begin{array}{l}\text { Empire Theatre } \\
\text { Co }\end{array}$ & Play & $7 / 28 / 06$ & \\
\hline $\begin{array}{l}\text { Uncle Tom's } \\
\text { Cabin }\end{array}$ & $\begin{array}{l}\text { Empire Theatre } \\
\text { Co }\end{array}$ & Play & $8 / 3 / 06$ & \\
\hline $\begin{array}{l}\text { Jack O } \\
\text { Diamond }\end{array}$ & $\begin{array}{l}\text { Empire Theatre } \\
\text { Co }\end{array}$ & Play & $8 / 6 / 06$ & \\
\hline Friends & $\begin{array}{l}\text { Maldon } \\
\text { Marquam }\end{array}$ & Play & $8 / 18 / 06$ & $.15 / .25 / .35$ \\
\hline Bimbo & & Acrobat & $8 / 25 / 06$ & $.15 / .25 / .35$ \\
\hline $\begin{array}{l}\text { Robert Webb } \\
\text { Lawrence }\end{array}$ & & Comedy & $8 / 25 / 06$ & $.15 / .25 / .35$ \\
\hline Vier Hill & & Illustrated Singer & $8 / 25 / 06$ & $.15 / .25 / .35$ \\
\hline $\begin{array}{l}\text { Desoto \& } \\
\text { Logan }\end{array}$ & & Musician & $8 / 25 / 06$ & $.15 / .25 / .35$ \\
\hline $\begin{array}{l}\text { A Tip on the } \\
\text { Suburban }\end{array}$ & The Lawrences & Sketch & $8 / 25 / 06$ & $.15 / .25 / .35$ \\
\hline
\end{tabular}




\begin{tabular}{|c|c|c|c|c|}
\hline \multicolumn{5}{|c|}{ Unique/Broadway/State Theatre - San Bernardino } \\
\hline Performance & Billed Star & Genre & Date & Prices \\
\hline $\begin{array}{l}\text { Evans \& } \\
\text { Evans }\end{array}$ & & Dancer & $8 / 27 / 06$ & $.15 / .25 / .35$ \\
\hline William Mack & & & $8 / 27 / 06$ & $.15 / .25 / .35$ \\
\hline Kitty Walsh & & Singer & $8 / 27 / 06$ & $.15 / .25 / .35$ \\
\hline $\begin{array}{l}\text { Vier Hill and } \\
\text { Nellie Hill }\end{array}$ & & Singer & $8 / 27 / 06$ & $.15 / .25 / .35$ \\
\hline $\begin{array}{l}\text { The } \\
\text { Irishman's } \\
\text { Pipe Dream }\end{array}$ & The Lawrences & Sketch & $8 / 27 / 06$ & $.15 / .25 / .35$ \\
\hline $\begin{array}{l}\text { Charley's } \\
\text { Aunt }\end{array}$ & $\begin{array}{l}\text { Cogley's } \\
\text { Comedy Co }\end{array}$ & Play & $9 / 3 / 06$ & \\
\hline $\begin{array}{l}\text { My Uncle } \\
\text { From Japan }\end{array}$ & & Play & 9/10/06 & \\
\hline Walter Trask & & Blackface Singer & $10 / 8 / 06$ & \\
\hline $\begin{array}{l}\text { Evelyn } \\
\text { Maxwell }\end{array}$ & & Singer & $10 / 8 / 06$ & \\
\hline $\begin{array}{l}\text { The } \\
\text { Frolicksome } \\
\text { Demon }\end{array}$ & & Sketch & $10 / 8 / 06$ & \\
\hline The Tourists & $\begin{array}{l}\text { Edward } \\
\text { Hutchison's } \\
\text { Musical } \\
\text { Comedy Co }\end{array}$ & Sketch & $10 / 8 / 06$ & \\
\hline Luy Withoft & & Singer & $10 / 15 / 06$ & \\
\hline $\begin{array}{l}\text { Martha } \\
\text { Ledover }\end{array}$ & & Singer & $10 / 15 / 06$ & \\
\hline $\begin{array}{l}\text { The Circus } \\
\text { Rider }\end{array}$ & $\begin{array}{l}\text { Cluxton, } \\
\text { Richmond \& Co }\end{array}$ & Sketch & $10 / 15 / 06$ & \\
\hline $\begin{array}{l}\text { At } \\
\text { Narrangansett }\end{array}$ & $\begin{array}{l}\text { Edward } \\
\text { Hutchison's } \\
\text { Musical } \\
\text { Comedy Co }\end{array}$ & Sketch & $10 / 15 / 06$ & \\
\hline Carl Brothers & & Comedy & $10 / 21 / 06$ & \\
\hline Joe Winschell & & Illustrated Singer & $10 / 21 / 06$ & \\
\hline $\begin{array}{l}\text { Yuma the } \\
\text { Mystery }\end{array}$ & & Novelty & $10 / 21 / 06$ & \\
\hline Doline Cole & & Singer & $10 / 21 / 06$ & \\
\hline $\begin{array}{l}\text { Bessie } \\
\text { Crawford }\end{array}$ & & Singer & $10 / 21 / 06$ & \\
\hline $\begin{array}{l}\text { The } \\
\text { Denounceme- } \\
\text { nt }\end{array}$ & $\begin{array}{l}\text { Robert } \\
\text { Warwick }\end{array}$ & Sketch & $10 / 21 / 06$ & \\
\hline Dolline Cole & & Blackface Singer & $10 / 29 / 06$ & \\
\hline
\end{tabular}




\begin{tabular}{|c|c|c|c|c|}
\hline \multicolumn{5}{|c|}{ Unique/Broadway/State Theatre - San Bernardino } \\
\hline Performance & Billed Star & Genre & Date & Prices \\
\hline $\begin{array}{l}\text { The Jolly } \\
\text { Jesters }\end{array}$ & & Comedy & $10 / 29 / 06$ & \\
\hline Lucy Witthoft & & Illustrated Singer & $10 / 29 / 06$ & \\
\hline $\begin{array}{l}\text { The Book } \\
\text { Agent }\end{array}$ & & Sketch & $10 / 29 / 06$ & \\
\hline Walter Franks & & Singer & $11 / 5 / 06$ & \\
\hline Lucy Witthoft & & Illustrated Singer & $11 / 5 / 06$ & \\
\hline $\begin{array}{l}\text { Leonard \& } \\
\text { Drake }\end{array}$ & & Sketch & $11 / 5 / 06$ & \\
\hline $\begin{array}{l}\text { Other } \\
\text { People's } \\
\text { Money }\end{array}$ & Cooley \& Co & Play & $11 / 9 / 06$ & \\
\hline Eddie Young & & Comedy & $11 / 30 / 06$ & $\begin{array}{l}.15 / .25 / .35 / . \\
50\end{array}$ \\
\hline John Hoffman & & Monologue & $11 / 30 / 06$ & $\begin{array}{l}.15 / .25 / .35 / . \\
50\end{array}$ \\
\hline $\begin{array}{l}\text { Gordon } \\
\text { Brothers }\end{array}$ & & Cycling & $11 / 30 / 06$ & $\begin{array}{l}.15 / .25 / .35 / . \\
50\end{array}$ \\
\hline Fischer Laird & & Illustrated Singer & $11 / 30 / 06$ & $\begin{array}{l}.15 / .25 / .35 / . \\
50\end{array}$ \\
\hline Lucy Witthoft & & Illustrated Singer & $11 / 30 / 06$ & $\begin{array}{l}.15 / .25 / .35 / . \\
50\end{array}$ \\
\hline $\begin{array}{l}\text { Black and } \\
\text { White }\end{array}$ & $\begin{array}{l}\text { Lawrence \& } \\
\text { Sheridan }\end{array}$ & Sketch & $11 / 30 / 06$ & $\begin{array}{l}.15 / .25 / .35 / . \\
50\end{array}$ \\
\hline Our Uncle & Conlon-Hanlett & Play & $12 / 5 / 06$ & \\
\hline The Hypnotist & & Play & $12 / 19 / 06$ & $.25 / .35 / .50$ \\
\hline Armento Bros & & Acrobat & $5 / 30 / 07$ & \\
\hline $\begin{array}{l}\text { Pose de } \\
\text { Plastique }\end{array}$ & $\begin{array}{l}\text { Unique Comedy } \\
\text { Co }\end{array}$ & Sketch & $5 / 30 / 07$ & \\
\hline $\begin{array}{l}\text { Major } \\
\text { Williams }\end{array}$ & & Juggler & $5 / 30 / 07$ & \\
\hline Henry Woods & & Punching & $5 / 30 / 07$ & \\
\hline $\begin{array}{l}\text { Willison \& } \\
\text { Flint }\end{array}$ & & Singer & $5 / 30 / 07$ & \\
\hline
\end{tabular}

Orpheum Theatre - San Bernardino

\begin{tabular}{|l|l|l|r|l|}
\hline Performance & Billed Star & Genre & Date & Prices \\
\hline $\begin{array}{l}\text { Martin and } \\
\text { Ridgeway }\end{array}$ & & Freak & $6 / 29 / 03$ & \\
\hline Joe Fox & & Comedian & $6 / 29 / 03$ & \\
\hline La Toska & & Juggler & $6 / 29 / 03$ & \\
\hline Mr. and Mrs. & & & $6 / 29 / 03$ & \\
\hline
\end{tabular}




\begin{tabular}{|c|c|c|c|c|}
\hline \multicolumn{5}{|c|}{ Orpheum Theatre - San Bernardino } \\
\hline Performance & Billed Star & Genre & Date & Prices \\
\hline Bob Shaw & & & & \\
\hline $\begin{array}{l}\text { Mrs. Harry } \\
\text { Deets }\end{array}$ & & & $6 / 29 / 03$ & \\
\hline Prof. Lansing & & Musician & $1 / 11 / 04$ & $.10 / .20$ \\
\hline $\begin{array}{l}\text { Edmons \& } \\
\text { Edmons }\end{array}$ & & Sketch & $1 / 11 / 04$ & $.10 / .20$ \\
\hline $\begin{array}{l}\text { Leslie } \\
\text { Sterling }\end{array}$ & & Soubrette & $1 / 11 / 04$ & $.10 / .20$ \\
\hline Claude Kelley & & & $1 / 11 / 04$ & $.10 / .20$ \\
\hline Joe Fox & & Comedian & $1 / 11 / 04$ & $.10 / .20$ \\
\hline $\begin{array}{l}\text { Happy } \\
\text { Hooligan } \\
\text { Poulter }\end{array}$ & & & $1 / 11 / 04$ & $.10 / .20$ \\
\hline $\begin{array}{l}\text { Clyde } \\
\text { Monterey }\end{array}$ & & Illustrated Singer & $1 / 18 / 04$ & $.10 / .20$ \\
\hline $\begin{array}{l}\text { Mabel } \\
\text { Maitland }\end{array}$ & & Dancer & $1 / 18 / 04$ & $.10 / .20$ \\
\hline The Sherers & & Musician & $1 / 18 / 04$ & $.10 / .20$ \\
\hline $\begin{array}{l}\text { Edmons \& } \\
\text { Edmons }\end{array}$ & & & $1 / 18 / 04$ & $.10 / .20$ \\
\hline $\begin{array}{l}\text { Happy } \\
\text { Hooligan } \\
\text { Poulter }\end{array}$ & & & $1 / 18 / 04$ & $.10 / .20$ \\
\hline Joe Fox & & Comedian & $1 / 18 / 04$ & $.10 / .20$ \\
\hline $\begin{array}{l}\text { The Black } \\
\text { Justice }\end{array}$ & $\begin{array}{l}\text { Joe Fox \& } \\
\text { Company }\end{array}$ & Sketch & $1 / 18 / 04$ & $.10 / .20$ \\
\hline Dan O'Neil & & Comedian & $1 / 25 / 04$ & \\
\hline La Toska & & Juggler & $1 / 25 / 04$ & \\
\hline $\begin{array}{l}\text { Morey and } \\
\text { Morey }\end{array}$ & & Singer & $1 / 25 / 04$ & \\
\hline $\begin{array}{l}\text { Tidings From } \\
\text { Home }\end{array}$ & $\begin{array}{l}\text { Verne and } \\
\text { O'Brien }\end{array}$ & Sketch & $1 / 25 / 04$ & \\
\hline $\begin{array}{l}\text { The Other } \\
\text { Fellow }\end{array}$ & & Sketch & $1 / 25 / 04$ & \\
\hline $\begin{array}{l}\text { The Black } \\
\text { Statue }\end{array}$ & $\begin{array}{l}\text { Joe Fox \& } \\
\text { Company }\end{array}$ & Sketch & $2 / 15 / 04$ & \\
\hline Charles Pope & & Comedian & $2 / 15 / 04$ & \\
\hline Effie Doreen & & Musician & $2 / 15 / 04$ & \\
\hline $\begin{array}{l}\text { The } \\
\text { Burroughs }\end{array}$ & & Sketch & $2 / 15 / 04$ & \\
\hline Buffalo Bill & $\begin{array}{l}\text { Joe Fox \& } \\
\text { Company }\end{array}$ & Sketch & $2 / 22 / 04$ & $.10 / .20$ \\
\hline The New Idea & Bence and & Sketch & $2 / 22 / 04$ & $.10 / .20$ \\
\hline
\end{tabular}




\begin{tabular}{|c|c|c|c|c|}
\hline \multicolumn{5}{|c|}{ Orpheum Theatre - San Bernardino } \\
\hline Performance & Billed Star & Genre & Date & Prices \\
\hline & Atler & & & \\
\hline Throsa & & Mechanical Doll & $2 / 22 / 04$ & $.10 / .20$ \\
\hline Daisy Darvin & & Singer & $2 / 22 / 04$ & $.10 / .20$ \\
\hline $\begin{array}{l}\text { Domestic } \\
\text { Repartee }\end{array}$ & $\begin{array}{l}\text { The } \\
\text { Burroughs }\end{array}$ & Sketch & $2 / 22 / 04$ & $.10 / .20$ \\
\hline $\begin{array}{l}\text { Nellie's } \\
\text { Lovers }\end{array}$ & $\begin{array}{l}\text { Joe Fox \& } \\
\text { Company }\end{array}$ & Sketch & $3 / 1 / 04$ & \\
\hline $\begin{array}{l}\text { Hines and } \\
\text { Speedy }\end{array}$ & & Animal Act & $3 / 1 / 04$ & \\
\hline JE Flood & & Barrel Jumper & $3 / 1 / 04$ & \\
\hline $\begin{array}{l}\text { Summers and } \\
\text { Winters }\end{array}$ & & Comedian & $3 / 1 / 04$ & \\
\hline Sadie Hayes & & Soubrette & $3 / 1 / 04$ & \\
\hline Delia Adams & & & $3 / 1 / 04$ & \\
\hline $\begin{array}{l}\text { A Hole in the } \\
\text { Wall }\end{array}$ & $\begin{array}{l}\text { Joe Fox \& } \\
\text { Company }\end{array}$ & Sketch & $3 / 8 / 04$ & \\
\hline $\begin{array}{l}\text { Phillips and } \\
\text { Armstrong }\end{array}$ & & Comedian & $3 / 8 / 04$ & \\
\hline OB Schmidt & & Comedian & $3 / 8 / 04$ & \\
\hline $\begin{array}{l}\text { Summers and } \\
\text { Winters }\end{array}$ & & Comedian & $3 / 8 / 04$ & \\
\hline Daisy Merrit & & Singer & $3 / 8 / 04$ & \\
\hline Mae DeHaven & & Soubrette & $3 / 8 / 04$ & \\
\hline $\begin{array}{l}\text { A Big Load of } \\
\text { Wood }\end{array}$ & $\begin{array}{l}\text { Joe Fox \& } \\
\text { Company }\end{array}$ & Sketch & $3 / 15 / 04$ & \\
\hline $\begin{array}{l}\text { Lawson and } \\
\text { Mack }\end{array}$ & & Comedian & $3 / 15 / 04$ & \\
\hline $\begin{array}{l}\text { Summers and } \\
\text { Winters }\end{array}$ & & Comedian & $3 / 15 / 04$ & \\
\hline $\begin{array}{l}\text { Charles } \\
\text { Gardner }\end{array}$ & & Monologue & $3 / 15 / 04$ & \\
\hline $\begin{array}{l}\text { Marie } \\
\text { Stoddard }\end{array}$ & & Impersonator & $3 / 15 / 04$ & \\
\hline $\begin{array}{l}\text { Square for a } \\
\text { Day }\end{array}$ & $\begin{array}{l}\text { Joe Fox \& } \\
\text { Company }\end{array}$ & Sketch & $3 / 22 / 04$ & \\
\hline Eddie Frank & & Comedian & $3 / 22 / 04$ & \\
\hline $\begin{array}{l}\text { Whiting and } \\
\text { Desmonde }\end{array}$ & & Singer & $3 / 22 / 04$ & \\
\hline Billy Hayes & & Singer/Dancer & $3 / 22 / 04$ & \\
\hline $\begin{array}{l}\text { Gardner and } \\
\text { Shaddard }\end{array}$ & & Sketch & $3 / 22 / 04$ & \\
\hline The Godfreys & & Acrobats & $4 / 4 / 04$ & \\
\hline
\end{tabular}




\begin{tabular}{|c|c|c|c|c|}
\hline \multicolumn{5}{|c|}{ Orpheum Theatre - San Bernardino } \\
\hline Performance & Billed Star & Genre & Date & Prices \\
\hline $\begin{array}{l}\text { Widow } \\
\text { Bedotte }\end{array}$ & $\begin{array}{l}\text { Joe Fox \& } \\
\text { Company }\end{array}$ & Sketch & $4 / 4 / 04$ & \\
\hline Sid Winters & & Dancer & $4 / 4 / 04$ & \\
\hline Homer Long & & Singer & $4 / 4 / 04$ & \\
\hline The Alarcons & & Singer/Dancer & $4 / 4 / 04$ & \\
\hline $\begin{array}{l}\text { Maxie } \\
\text { Mitchell }\end{array}$ & & Soubrette & $4 / 4 / 04$ & \\
\hline $\begin{array}{l}\text { Americans } \\
\text { Abroad }\end{array}$ & $\begin{array}{l}\text { Joe Fox \& } \\
\text { Company }\end{array}$ & Sketch & $4 / 11 / 04$ & $.10 / .20$ \\
\hline Sid Winters & & Dancer & $4 / 11 / 04$ & $.10 / .20$ \\
\hline Homer Long & & Singer & $4 / 11 / 04$ & $.10 / .20$ \\
\hline $\begin{array}{l}\text { Carberry and } \\
\text { Stanton }\end{array}$ & & Sketch & $4 / 11 / 04$ & $.10 / .20$ \\
\hline $\begin{array}{l}\text { A Domestic } \\
\text { Story }\end{array}$ & $\begin{array}{l}\text { The } \\
\text { Burroughs }\end{array}$ & Sketch & $4 / 11 / 04$ & $.10 / .20$ \\
\hline $\begin{array}{l}\text { Maxie } \\
\text { Mitchell }\end{array}$ & & Soubrette & $4 / 11 / 04$ & $.10 / .20$ \\
\hline $\begin{array}{l}\text { The Siamese } \\
\text { Twins }\end{array}$ & $\begin{array}{l}\text { Joe Fox \& } \\
\text { Company }\end{array}$ & Sketch & $4 / 25 / 04$ & \\
\hline Forbes \& Co & & Comedian & $4 / 25 / 04$ & \\
\hline $\begin{array}{l}\text { May and } \\
\text { Edna De Mar }\end{array}$ & & Impersonator & $4 / 25 / 04$ & \\
\hline The Plunger & $\begin{array}{l}\text { Joe Fox \& } \\
\text { Company }\end{array}$ & Sketch & $5 / 2 / 04$ & \\
\hline $\begin{array}{l}\text { Forbes and } \\
\text { Forbes }\end{array}$ & & $\begin{array}{l}\text { Blackface } \\
\text { Comedian }\end{array}$ & $5 / 2 / 04$ & \\
\hline Cyrena Wolfe & & Blackface Singer & $5 / 2 / 04$ & \\
\hline $\begin{array}{l}\text { Harrison and } \\
\text { Malumby }\end{array}$ & & Comedian & $5 / 2 / 04$ & \\
\hline $\begin{array}{l}\text { Eugene De } \\
\text { Bell }\end{array}$ & & Illustrated Singer & $5 / 2 / 04$ & \\
\hline $\begin{array}{l}\text { The } \\
\text { Masquerade } \\
\text { Ball }\end{array}$ & $\begin{array}{l}\text { Joe Fox \& } \\
\text { Company }\end{array}$ & $\begin{array}{l}\text { Blackface } \\
\text { Comedian }\end{array}$ & $5 / 9 / 04$ & \\
\hline The Lamonts & & Animal Act & $5 / 9 / 04$ & \\
\hline $\begin{array}{l}\text { Eugene De } \\
\text { Bell }\end{array}$ & & Illustrated Singer & $5 / 9 / 04$ & \\
\hline Cyrena Wolfe & & Singer & $5 / 9 / 04$ & \\
\hline Frank Forbes & & Singer & $5 / 9 / 04$ & \\
\hline $\begin{array}{l}\text { Damaria and } \\
\text { Orlando }\end{array}$ & & Singer/Dancer & $5 / 9 / 04$ & \\
\hline $\begin{array}{l}\text { Marco } \\
\text { Brothers }\end{array}$ & & Acrobats & $5 / 16 / 04$ & \\
\hline
\end{tabular}




\begin{tabular}{|c|c|c|c|c|}
\hline \multicolumn{5}{|c|}{ Orpheum Theatre - San Bernardino } \\
\hline Performance & Billed Star & Genre & Date & Prices \\
\hline $\begin{array}{l}\text { The Minstrel } \\
\text { Man }\end{array}$ & $\begin{array}{l}\text { Joe Fox \& } \\
\text { Company }\end{array}$ & $\begin{array}{l}\text { Blackface } \\
\text { Comedian }\end{array}$ & $5 / 16 / 04$ & \\
\hline The Lamonts & & Animal Act & $5 / 16 / 04$ & \\
\hline $\begin{array}{l}\text { Eugene De } \\
\text { Bell }\end{array}$ & & Illustrated Singer & $5 / 16 / 04$ & \\
\hline Olive Hare & & Soubrette & $5 / 16 / 04$ & \\
\hline Amateur Acts & & Amateur & $5 / 19 / 04$ & \\
\hline Joe Fox & & Monologue & $5 / 23 / 04$ & \\
\hline Kitty & $\begin{array}{l}\text { Joe Fox \& } \\
\text { Company }\end{array}$ & Sketch & $5 / 23 / 04$ & \\
\hline The Lamonts & & Animal Act & $5 / 23 / 04$ & \\
\hline $\begin{array}{l}\text { Eugene De } \\
\text { Bell }\end{array}$ & & Illustrated Singer & $5 / 23 / 04$ & \\
\hline The Jacks & & Sketch & $5 / 23 / 04$ & \\
\hline $\begin{array}{l}\text { Ethel } \\
\text { Cossette }\end{array}$ & & Soubrette & $5 / 23 / 04$ & \\
\hline $\begin{array}{l}\text { The } \\
\text { Pattersons }\end{array}$ & & Acrobats & $5 / 30 / 04$ & \\
\hline Joe Fox & & Monologue & $5 / 30 / 04$ & \\
\hline $\begin{array}{l}\text { United States } \\
\text { Mail }\end{array}$ & $\begin{array}{l}\text { Joe Fox \& } \\
\text { Company }\end{array}$ & Sketch & $5 / 30 / 04$ & \\
\hline Little Pat & & Child Act & $5 / 30 / 04$ & \\
\hline $\begin{array}{l}\text { Eugene De } \\
\text { Bell }\end{array}$ & & Illustrated Singer & $5 / 30 / 04$ & \\
\hline $\begin{array}{l}\text { Ethel } \\
\text { Cossette }\end{array}$ & & Soubrette & $5 / 30 / 04$ & \\
\hline Joe Fox & & Singer & $6 / 6 / 04$ & \\
\hline $\begin{array}{l}\text { The Rival } \\
\text { Dummies }\end{array}$ & $\begin{array}{l}\text { Joe Fox \& } \\
\text { Company }\end{array}$ & Sketch & $6 / 6 / 04$ & \\
\hline Adkins & & $\begin{array}{l}\text { Female } \\
\text { Impersonator }\end{array}$ & $6 / 6 / 04$ & \\
\hline $\begin{array}{l}\text { Eugene De } \\
\text { Bell }\end{array}$ & & Illustrated Singer & $6 / 6 / 04$ & \\
\hline $\begin{array}{l}\text { Smith and } \\
\text { Walsh }\end{array}$ & & Juggler & $6 / 6 / 04$ & \\
\hline $\begin{array}{l}\text { Hamlin and } \\
\text { Hamlin }\end{array}$ & & Singer/Dancer & $6 / 6 / 04$ & \\
\hline $\begin{array}{l}\text { The } \\
\text { Manager's } \\
\text { Troubles }\end{array}$ & $\begin{array}{l}\text { Joe Fox \& } \\
\text { Company }\end{array}$ & Sketch & $6 / 13 / 04$ & \\
\hline $\begin{array}{l}\text { Eugene De } \\
\text { Bell }\end{array}$ & & Illustrated Singer & $6 / 13 / 04$ & \\
\hline Hamlin and & & Singer/Dancer & $6 / 13 / 04$ & \\
\hline
\end{tabular}




\begin{tabular}{|c|c|c|c|c|}
\hline \multicolumn{5}{|c|}{ Orpheum Theatre - San Bernardino } \\
\hline Performance & Billed Star & Genre & Date & Prices \\
\hline Hamlin & & & & \\
\hline $\begin{array}{l}\text { The Daffy } \\
\text { Dame and the } \\
\text { Tad }\end{array}$ & $\begin{array}{l}\text { Paul LaDrew } \\
\text { and Fred } \\
\text { LaZone }\end{array}$ & Sketch & $6 / 13 / 04$ & \\
\hline $\begin{array}{l}\text { Happy } \\
\text { Hooligan }\end{array}$ & $\begin{array}{l}\text { Marve } \\
\text { Kingdom }\end{array}$ & Cycling & $6 / 13 / 04$ & \\
\hline The Stones & & Acrobats & $6 / 20 / 04$ & \\
\hline $\begin{array}{l}\text { The } \\
\text { Hypnotist }\end{array}$ & $\begin{array}{l}\text { Joe Fox \& } \\
\text { Company }\end{array}$ & Sketch & $6 / 20 / 04$ & \\
\hline $\begin{array}{l}\text { Eugene De } \\
\text { Bell }\end{array}$ & & Illustrated Singer & $6 / 20 / 04$ & \\
\hline $\begin{array}{l}\text { Josephine } \\
\text { Cromwell }\end{array}$ & & Singer & $6 / 20 / 04$ & \\
\hline $\begin{array}{l}\text { The } \\
\text { O'Hoolihans' } \\
\text { Troubles }\end{array}$ & $\begin{array}{l}\text { Paul LaDrew } \\
\text { and Fred } \\
\text { LaZone }\end{array}$ & Sketch & $6 / 20 / 04$ & \\
\hline Joe Fox & & Comedian & $6 / 27 / 04$ & $.10 / .20$ \\
\hline $\begin{array}{l}\text { Moving In } \\
\text { and Moving } \\
\text { On }\end{array}$ & $\begin{array}{l}\text { Joe Fox \& } \\
\text { Company }\end{array}$ & Sketch & $6 / 27 / 04$ & $.10 / .20$ \\
\hline Lola Montez & & Dancer & $6 / 27 / 04$ & $.10 / .20$ \\
\hline $\begin{array}{l}\text { Eugene De } \\
\text { Bell }\end{array}$ & & Illustrated Singer & $6 / 27 / 04$ & $.10 / .20$ \\
\hline $\begin{array}{l}\text { Jumping a } \\
\text { Board Bill }\end{array}$ & $\begin{array}{l}\text { McDowell \& } \\
\text { Duffy }\end{array}$ & Sketch & $6 / 27 / 04$ & $.10 / .20$ \\
\hline $\begin{array}{l}\text { LaDrew and } \\
\text { LaZone }\end{array}$ & & Sketch & $6 / 27 / 04$ & $.10 / .20$ \\
\hline Joe Fox & & Comedian & $7 / 4 / 04$ & \\
\hline Epitaphs & $\begin{array}{l}\text { Joe Fox \& } \\
\text { Company }\end{array}$ & Sketch & $7 / 4 / 04$ & \\
\hline Malcolm & & Blackface Juggler & $7 / 4 / 04$ & \\
\hline $\begin{array}{l}\text { Eugene De } \\
\text { Bell }\end{array}$ & & Illustrated Singer & $7 / 4 / 04$ & \\
\hline $\begin{array}{l}\text { Carlson } \\
\text { Sisters }\end{array}$ & & Singer/Dancer & $7 / 4 / 04$ & \\
\hline $\begin{array}{l}\text { Reno and } \\
\text { Zolo }\end{array}$ & & Sketch & $7 / 11 / 04$ & \\
\hline Joe Fox & & Comedian & $7 / 11 / 04$ & \\
\hline $\begin{array}{l}\text { Lunatic } \\
\text { Asylum }\end{array}$ & $\begin{array}{l}\text { Joe Fox \& } \\
\text { Company }\end{array}$ & Sketch & $7 / 11 / 04$ & \\
\hline Malcolm & & Blackface Juggler & $7 / 11 / 04$ & \\
\hline $\begin{array}{l}\text { Eugene De } \\
\text { Bell }\end{array}$ & & Illustrated Singer & $7 / 11 / 04$ & \\
\hline
\end{tabular}




\begin{tabular}{|c|c|c|c|c|}
\hline \multicolumn{5}{|c|}{ Orpheum Theatre - San Bernardino } \\
\hline Performance & Billed Star & Genre & Date & Prices \\
\hline $\begin{array}{l}\text { Carlson } \\
\text { Sisters }\end{array}$ & & Singer/Dancer & $7 / 11 / 04$ & \\
\hline DeShields & & Equilibrist & $7 / 18 / 04$ & \\
\hline Blue Glass & $\begin{array}{l}\text { Joe Fox \& } \\
\text { Company }\end{array}$ & Sketch & $7 / 18 / 04$ & \\
\hline Volkyra & & Equilibrist & $7 / 18 / 04$ & \\
\hline $\begin{array}{l}\text { Eugene De } \\
\text { Bell }\end{array}$ & & Illustrated Singer & $7 / 18 / 04$ & \\
\hline $\begin{array}{l}\text { The French } \\
\text { Maid }\end{array}$ & $\begin{array}{l}\text { Hadley and } \\
\text { Archer }\end{array}$ & Sketch & $7 / 18 / 04$ & \\
\hline $\begin{array}{l}\text { The Three } \\
\text { Hunters }\end{array}$ & $\begin{array}{l}\text { Joe Fox \& } \\
\text { Company }\end{array}$ & Sketch & $7 / 25 / 04$ & \\
\hline Joe Fox & & Comedian & $7 / 25 / 04$ & \\
\hline Happy Tramp & $\begin{array}{l}\text { Boyle and } \\
\text { Wilson }\end{array}$ & $\begin{array}{l}\text { Blackface } \\
\text { Comedian }\end{array}$ & $7 / 25 / 04$ & \\
\hline Mozarto & & Musician & $7 / 25 / 04$ & \\
\hline $\begin{array}{l}\text { Eugene De } \\
\text { Bell }\end{array}$ & & Illustrated Singer & $7 / 25 / 04$ & \\
\hline $\begin{array}{l}\text { Cinderella's } \\
\text { Dream }\end{array}$ & $\begin{array}{l}\text { Hadley and } \\
\text { Archer }\end{array}$ & Sketch & $7 / 25 / 04$ & \\
\hline $\begin{array}{l}\text { The } \\
\text { Automatic } \\
\text { Bellow }\end{array}$ & $\begin{array}{l}\text { Joe Fox \& } \\
\text { Company }\end{array}$ & Sketch & $8 / 2 / 04$ & \\
\hline $\begin{array}{l}\text { Mike and } \\
\text { Mike }\end{array}$ & & Animal Act & $8 / 2 / 04$ & \\
\hline Newell & & $\begin{array}{l}\text { Female } \\
\text { Impersonator }\end{array}$ & $8 / 2 / 04$ & \\
\hline $\begin{array}{l}\text { Eugene De } \\
\text { Bell }\end{array}$ & & Illustrated Singer & $8 / 2 / 04$ & \\
\hline The Pantas & & Animal Act & $8 / 2 / 04$ & \\
\hline $\begin{array}{l}\text { The Three } \\
\text { Renos }\end{array}$ & & Acrobats & $9 / 6 / 04$ & \\
\hline $\begin{array}{l}\text { Tony Toy, the } \\
\text { Knight of the } \\
\text { Road }\end{array}$ & $\begin{array}{l}\text { Joe Fox \& } \\
\text { Company }\end{array}$ & Sketch & $9 / 6 / 04$ & \\
\hline Joe Fox & & Comedian & $9 / 6 / 04$ & \\
\hline $\begin{array}{l}\text { Eugene De } \\
\text { Bell }\end{array}$ & & Illustrated Singer & $9 / 6 / 04$ & \\
\hline $\begin{array}{l}\text { Harney and } \\
\text { Haynes }\end{array}$ & & $\begin{array}{l}\text { Blackface } \\
\text { Comedian }\end{array}$ & $9 / 6 / 04$ & \\
\hline $\begin{array}{l}\text { Mrs. Harry } \\
\text { Deets }\end{array}$ & & Sketch & $9 / 6 / 04$ & \\
\hline Little Addie & & Soubrette & $9 / 6 / 04$ & \\
\hline
\end{tabular}




\begin{tabular}{|c|c|c|c|c|}
\hline \multicolumn{5}{|c|}{ Orpheum Theatre - San Bernardino } \\
\hline Performance & Billed Star & Genre & Date & Prices \\
\hline Yeager & & & & \\
\hline Joe Fox & & Comedian & 9/13/04 & \\
\hline E Will Bensey & & Equilibrist & $9 / 13 / 04$ & \\
\hline $\begin{array}{l}\text { Eugene De } \\
\text { Bell }\end{array}$ & & Illustrated Singer & $9 / 13 / 04$ & \\
\hline $\begin{array}{l}\text { Kronas, } \\
\text { Arthur and } \\
\text { Bessie }\end{array}$ & & Sketch & $9 / 13 / 04$ & \\
\hline $\begin{array}{l}\text { Gordon and } \\
\text { Gilbert }\end{array}$ & & Sketch & $9 / 13 / 04$ & \\
\hline $\begin{array}{l}\text { Mrs. Harry } \\
\text { Deets }\end{array}$ & & Sketch & $9 / 13 / 04$ & \\
\hline $\begin{array}{l}\text { Brocky } \\
\text { Morgan }\end{array}$ & & Sketch & $9 / 13 / 04$ & \\
\hline $\begin{array}{l}\text { McGinty at } \\
\text { the Seaside }\end{array}$ & $\begin{array}{l}\text { Joe Fox \& } \\
\text { Company }\end{array}$ & Sketch & $9 / 20 / 04$ & \\
\hline Barnold & & Animal Act & $9 / 20 / 04$ & \\
\hline $\begin{array}{l}\text { Eugene De } \\
\text { Bell }\end{array}$ & & Illustrated Singer & $9 / 20 / 04$ & \\
\hline $\begin{array}{l}\text { Uncle } \\
\text { Joshua's Visit }\end{array}$ & $\begin{array}{l}\text { Hooper and } \\
\text { Burrell }\end{array}$ & Sketch & $9 / 20 / 04$ & \\
\hline $\begin{array}{l}\text { Kenton and } \\
\text { Sutton }\end{array}$ & & Comedian & $9 / 20 / 04$ & \\
\hline $\begin{array}{l}\text { Mrs. Harry } \\
\text { Deets }\end{array}$ & & Sketch & $9 / 20 / 04$ & \\
\hline $\begin{array}{l}\text { Little Addie } \\
\text { Yeager }\end{array}$ & & Soubrette & $9 / 20 / 04$ & \\
\hline The Voltons & & Acrobats & $9 / 27 / 04$ & \\
\hline $\begin{array}{l}\text { The Steamer } \\
\text { Viola }\end{array}$ & $\begin{array}{l}\text { Joe Fox \& } \\
\text { Company }\end{array}$ & Sketch & $9 / 27 / 04$ & \\
\hline $\begin{array}{l}\text { Eugene De } \\
\text { Bell }\end{array}$ & & Illustrated Singer & $9 / 27 / 04$ & \\
\hline $\begin{array}{l}\text { The } \\
\text { McShaffreys }\end{array}$ & & Musical Gypsies & $9 / 27 / 04$ & \\
\hline Maud DeAlma & & Singer/Dancer & $9 / 27 / 04$ & \\
\hline $\begin{array}{l}\text { Kenton and } \\
\text { Sutton }\end{array}$ & & Sketch & 9/27/04 & \\
\hline $\begin{array}{l}\text { Mrs. Harry } \\
\text { Deets }\end{array}$ & & Sketch & $9 / 27 / 04$ & \\
\hline $\begin{array}{l}\text { Way Down } \\
\text { South }\end{array}$ & $\begin{array}{l}\text { Joe Fox \& } \\
\text { Company }\end{array}$ & Sketch & $10 / 3 / 04$ & \\
\hline Joe Ellis & & Comedian & $10 / 3 / 04$ & \\
\hline Eugene De & & Illustrated Singer & $10 / 3 / 04$ & \\
\hline
\end{tabular}




\begin{tabular}{|c|c|c|c|c|}
\hline \multicolumn{5}{|c|}{ Orpheum Theatre - San Bernardino } \\
\hline Performance & Billed Star & Genre & Date & Prices \\
\hline Bell & & & & \\
\hline $\begin{array}{l}\text { The Sisters } \\
\text { Demar }\end{array}$ & & Singer/Dancer & $10 / 3 / 04$ & \\
\hline Maud DeAlma & & Singer/Dancer & $10 / 3 / 04$ & \\
\hline $\begin{array}{l}\text { Mr. and Mrs. } \\
\text { Harry Deets }\end{array}$ & & Sketch & $10 / 3 / 04$ & \\
\hline Desdemona & $\begin{array}{l}\text { The Lancaster } \\
\text { Trio }\end{array}$ & Sketch & $10 / 3 / 04$ & \\
\hline $\begin{array}{l}\text { Smith, Brown } \\
\text { and } \\
\text { Summerton }\end{array}$ & $\begin{array}{l}\text { Joe Fox \& } \\
\text { Company }\end{array}$ & Sketch & $10 / 10 / 04$ & \\
\hline $\begin{array}{l}\text { Eugene De } \\
\text { Bell }\end{array}$ & & Illustrated Singer & $10 / 10 / 04$ & \\
\hline $\begin{array}{l}\text { Juggling } \\
\text { Burkes }\end{array}$ & & Juggler & $10 / 10 / 04$ & \\
\hline $\begin{array}{l}\text { Bacon and } \\
\text { Vane }\end{array}$ & & Sketch & $10 / 10 / 04$ & \\
\hline $\begin{array}{l}\text { Plaisted } \\
\text { Loraine }\end{array}$ & & Soubrette & $10 / 10 / 04$ & \\
\hline
\end{tabular}

Edison Theatre - San Bernardino

\begin{tabular}{|l|l|l|r|l|}
\hline Performance & Billed Star & \multicolumn{1}{|c|}{ Genre } & \multicolumn{1}{|c|}{ Date } & \multicolumn{1}{|c|}{ Prices } \\
\hline $\begin{array}{l}\text { John } \\
\text { Donovan }\end{array}$ & & & $4 / 11 / 04$ & $.10 / .20$ \\
\hline $\begin{array}{l}\text { Thomas } \\
\text { Armstrong }\end{array}$ & & $\begin{array}{l}\text { lllustrated } \\
\text { Singer }\end{array}$ & $4 / 11 / 04$ & $.10 / .20$ \\
\hline $\begin{array}{l}\text { Miner and } \\
\text { Galbreth }\end{array}$ & & Singer & $4 / 11 / 04$ & $.10 / .20$ \\
\hline $\begin{array}{l}\text { Mabel } \\
\text { Humbert }\end{array}$ & & Soubrette & $4 / 11 / 04$ & $.10 / .20$ \\
\hline $\begin{array}{l}\text { The Lady and } \\
\text { the } \\
\text { Messenger }\end{array}$ & The Gilens & Sketch & $4 / 11 / 04$ & $.10 / .20$ \\
\hline $\begin{array}{l}\text { Thomas } \\
\text { Armstrong }\end{array}$ & & Singer/Dancer & $4 / 25 / 04$ & \\
\hline $\begin{array}{l}\text { AD Miller } \\
\text { The }\end{array}$ & & Illustrated & $4 / 25 / 04$ & \\
\hline $\begin{array}{l}\text { Photograph } \\
\text { Gallery }\end{array}$ & Comedian & Singer & & \\
\hline $\begin{array}{l}\text { Tommy } \\
\text { Armstrong }\end{array}$ & & Sketch & $4 / 25 / 04$ & \\
\hline AD Miller & & Singer & & \\
\hline
\end{tabular}




\begin{tabular}{|c|c|c|c|c|}
\hline \multicolumn{5}{|c|}{ Edison Theatre - San Bernardino } \\
\hline Performance & Billed Star & Genre & Date & Prices \\
\hline & & Singer & & \\
\hline $\begin{array}{l}\text { Picking the } \\
\text { Winner }\end{array}$ & $\begin{array}{l}\text { Kehoe and } \\
\text { Rainer }\end{array}$ & Sketch & $5 / 2 / 04$ & \\
\hline Nellie Hilyer & & Singer & $5 / 2 / 04$ & \\
\hline $\begin{array}{l}\text { Jenkins and } \\
\text { O'Neve }\end{array}$ & & Sketch & $5 / 2 / 04$ & \\
\hline
\end{tabular}

\begin{tabular}{|c|c|c|c|c|}
\hline \multicolumn{5}{|c|}{ Lyric Theatre - San Bernardino } \\
\hline Performance & Billed Star & Genre & Date & Prices \\
\hline $\begin{array}{l}\text { Wilson \& } \\
\text { Moran }\end{array}$ & & & $5 / 2 / 04$ & $.10 / .20$ \\
\hline $\begin{array}{l}\text { Stanley and } \\
\text { Scanlon }\end{array}$ & & Singer & $5 / 2 / 04$ & $.10 / .20$ \\
\hline Rube Simms & & Comedian & $5 / 2 / 04$ & $.10 / .20$ \\
\hline $\begin{array}{l}\text { Walter } \\
\text { Wilson }\end{array}$ & & $\begin{array}{l}\text { Illustrated } \\
\text { Singer }\end{array}$ & $5 / 2 / 04$ & $.10 / .20$ \\
\hline $\begin{array}{l}\text { McCuen and } \\
\text { Grant }\end{array}$ & & Acrobats & $5 / 9 / 04$ & \\
\hline $\begin{array}{l}\text { Thomas } \\
\text { Hefron }\end{array}$ & & Comedian & $5 / 9 / 04$ & \\
\hline $\begin{array}{l}\text { Wilson \& } \\
\text { Moran }\end{array}$ & & Sketch & $5 / 9 / 04$ & \\
\hline $\begin{array}{l}\text { Walter } \\
\text { Wilson }\end{array}$ & & Singer & $5 / 9 / 04$ & \\
\hline Faits \& Co & & Magic & $2 / 18 / 05$ & $.10 / .20 / .30$ \\
\hline
\end{tabular}


Selected Bibliography

Books

Ahlquist, Karen. Democracy at the Opera: Music, Theater, and Culture in New York City, 1815-60. Urbana: University of Illinois Press, 1997.

Allen, Robert C. Horrible Prettiness: Burlesque and American Culture. Chapel Hill: University of North Carolina Press, 1991.

Barth, Gunther. City People: The Rise of Modern City Culture in Nineteenth-Century America. New York: Oxford University Press, 1980.

Cohan, George M. Twenty Years on Broadway, and the Years It Took to Get There: The True Story of a Trouper's Life from the Cradle to the "Closed Shop." Paperback ed. Westport, CT: Greenwood Press, 1971.

Cullen, Frank, Florence Hackman, and Donald McNeilly. Vaudeville, Old \& New: An Encyclopedia of Variety Performers in America. New York: Routledge, 2007.

Davis, Janet M. The Circus Age: Culture \& Society Under the American Bigtop. Chapel Hill: University of North Carolina Press, 2002.

Davis, Lee. Scandals and Follies: The Rise and Fall of the Great Broadway Revue. 1st ed. New York: Limelight Editions, 2000.

Dennett, Andrea Stulman. Weird and Wonderful: The Dime Museum in America. New York: New York University Press, 1997.

DiMeglio, John E. Vaudeville U.S.A. Bowling Green, OH: Bowling Green University Popular Press, 1973.

Duffy, Susan. American Labor on Stage: Dramatic Interpretations of The Steel and Textile Industries in the 1930s. Westport, CT: Greenwood Press, 1996.

Elliott, Eugene C. A History of Variety-Vaudeville in Seattle from the Beginning to 1914. Seattle: University of Washington Press, 1944.

Fields, Armond. Lillian Russell: a Biography of "America's Beauty." Jefferson, N.C: McFarland, 1999.

Finson, Jon W. The Voices That Are Gone: Themes in Nineteenth-Century American Popular Song. New York: Oxford University Press, 1994.

Fisher, James. Eddie Cantor: A Bio-Bibliography. Westport, CT: Greenwood Press, 1997. 
Forbes, Camille F. Introducing Bert Williams: Burnt Cork, Broadway, and The Story of America's First Black Star. New York: Basic Civitas, 2008.

Gilbert, Douglas. American Vaudeville, Its Life and Times. New York: Dover Publications, 1963.

- - . Lost Chords, the Diverting Story of American Popular Songs. Garden City, NY: Doubleday, Doran and Co., Inc, 1942.

Golden, George Fuller. My Lady Vaudeville and Her White Rats. New York: The White Rats of America, 1909.

Goodwin, Nat C., and Lester Donahue Performing Arts Collection. Nat Goodwin's Book. Boston: R. G. Badger, 1914.

Green, Abel. Show Biz, from Vaude to Video. 1st ed. New York: Holt, 1951.

Hall, Roger A. Performing the American Frontier, 1870-1906. New York: Cambridge University Press, 2001.

Hamm, Charles. Yesterdays: Popular Song in America. 1st ed. New York: Norton, 1979.

Harris, Chas K. After the Ball, Forty Years of Melody; an Autobiography. New York: FrankMaurice, Inc, 1926.

Kasson, John F. Houdini, Tarzan, and the Perfect Man: The White Male Body and the Challenge of Modernity in America. New York: Hill and Wang, 2001.

Kattwinkel, Susan. Tony Pastor Presents: Afterpieces from the Vaudeville Stage. Westport, CT: Greenwood Press, 1998.

Kibler, M. Alison. Rank Ladies: Gender and Cultural Hierarchy in American Vaudeville. Chapel Hill: University of North Carolina Press, 1999.

Koger, Alicia Kae. "A Critical Analysis of Edward Harrigan's Comedy." Ph.D. diss., University of Michigan, 1984.

Lahr, John. Notes on a Cowardly Lion; the Biography of Bert Lahr. 1st ed. New York: Knopf, 1969.

Laurie, Joe. Vaudeville: From the Honky-tonks to the Palace. 1st ed. New York: Holt, 1953.

Lears, T. J. Jackson. Rebirth of a Nation: The Making of Modern America, 1877-1920. 1st ed. New York: HarperCollins, 2009. 
Levine, Lawrence W. Highbrow/Lowbrow: The Emergence of Cultural Hierarchy in America. Cambridge: Harvard University Press, 1988.

Lewis, Robert M., ed. From Traveling Show to Vaudeville: Theatrical Spectacle in America, 1830-1910. Baltimore, Md: Johns Hopkins University Press, 2003.

Lott, Eric. Love and Theft: Blackface Minstrelsy and the American Working Class. New York: Oxford University Press, 1993.

Lowry, Ed, and Paul M Levitt. Vaudeville humor: The Collected Jokes, Routines, and Skits of Ed Lowry. Carbondale, IL: Southern Illinois University Press, 2002.

Lyons, Jimmy. Encyclopedia of Stage Material for Professional Entertainers, Clubs, Lodges, Comedians, or Any One Else Who Desires to Laugh: Containing Witty Jokes, Recitations, Sidewalk Conversation, Monologues, After Dinner Stories, Playlets, Minstrel Show, and Other Miscellaneous Comedy Matter. Boston: Walter H. Baker Company, 1925.

Marks, Edward B. They All Sang: From Tony Pastor to Rudy Vallee. New York: Viking Press, 1935.

Marx, Groucho. Groucho and Me. 1st Da Capo Press ed. New York: Da Capo Press, 1995.

McCabe, John. George M. Cohan: The Man Who Owned Broadway. 1st ed. Garden City, NY: Doubleday, 1973.

McLean, Albert F. American Vaudeville as Ritual. Lexington, KY: University of Kentucky Press, 1965.

McNamara, Brooks. Step Right Up. 1st ed. Garden City, NY: Doubleday, 1976.

Moody, Richard. Ned Harrigan: From Corlear's Hook to Herald Square. Chicago: NelsonHall, 1980.

Nunis, Jr., Doyce B., ed. Southern California Local History: A Gathering of the Writings of W.W. Robinson. Los Angeles: Historical Society of Southern California, 1993.

Page, Brett. Writing for Vaudeville: With Nine Complete Examples of Various Vaudeville Forms by Richard Harding Davis, Aaron Hoffman, Edgar Allan Woolfe, Taylor Granville, Louis Weslyn, Arthur Denvir, and James Madison. Springfield, MA: Home Correspondence School, 1915.

Pastor, Tony. Tony Pastor's Stories and Jokes. New York: W. Small and Co., 1872.

Rodgers, Daniel T. Atlantic Crossings: Social Politics in a Progressive Age. Cambridge: Belknap Press of Harvard University Press, 1998. 
Root, Deane L. American Popular Stage Music, 1860-1880. Ann Arbor, Mich: UMI Research Press, 1981.

Rosenzweig, Roy. Eight Hours for What We Will: Workers and Leisure in an Industrial City, 1870-1920. New York: Cambridge University Press, 1983.

Rubin, Joan Shelley. The Making of Middlebrow Culture. Chapel Hill: University of North Carolina Press, 1992.

Sanjek, Russell. American Popular Music and Its Business: The First Four Hundred Years. New York: Oxford University Press, 1988.

Sante, Luc. Low Life: Lures and Snares of Old New York. 1st ed. New York: Farrar Straus Giroux, 1991.

Schuiling, Walter C., and San Bernardino County Museum Association. San Bernardino County, Land of Contrasts. 1st ed. Woodland Hills, CA: Windsor Publications, 1984.

Slide, Anthony, ed. Selected Vaudeville Criticism. Metuchen, NJ: Scarecrow Press, 1988.

-——. The Encyclopedia of Vaudeville. Westport, CT.: Greenwood Press, 1994.

Slout, William L. Theatre in a Tent: The Development of a Provincial Entertainment. Bowling Green, OH: Bowling Green University Popular Press, 1972.

Smith, Bill. The Vaudevillians. New York: Macmillan, 1976.

Smith, Cecil Michner, and Glenn Litton. Musical Comedy in America: From The Black Crook to South Pacific. New York: Theatre Arts Books, 1981.

Snyder, Robert W. The Voice of the City: Vaudeville and Popular Culture in New York. New York: Oxford University Press, 1989.

Sobel, Bernard. A Pictorial History of Vaudeville. New York: Bonanza Books, 1961.

Spitzer, Marian. The Palace. 1st ed. New York: Atheneum, 1969.

Tucker, Sophie. Some of These Days; the Autobiography of Sophie Tucker. Garden City, NY: Doubleday, Doran and Company, Inc., 1945.

Weisberg, Bradley Eugene. "A History of the Wyatt Opera House." M.A. thesis, San Diego State University, 1991. A.K. Smiley Public Library (Heritage Room).

Wertheim, Arthur Frank, ed. The Papers of Will Rogers: From Vaudeville to Broadway: September 1908 - August 1915. Norman, OK: University of Oklahoma Press, 2001. 
Wertheim, Arthur Frank, and Barbara Bair, eds. The Papers of Will Rogers: The Early Years. Norman, OK: University of Oklahoma Press, 1996.

West, Mae. Goodness Had Nothing to Do with It: The Autobiography of Mae West. Paperback edition. New York: Belvedere, 1981.

Wiebe, Robert H. The Search for Order, 1877-1920. New York: Hill and Wang, 1967.

Willson, Clair Eugene. Mimes and Miners: A Historical Study of the Theater in Tombstone. Tucson, AZ: University of Arizona, 1935.

Wilmeth, Don B. Variety Entertainment and Outdoor Amusements: a Reference Guide. Westport, CT: Greenwood Press, 1982.

Zellers, Parker. Tony Pastor: Dean of the Vaudeville Stage. Ypsilanti, MI: Eastern Michigan University Press, 1971.

\section{Newspaper Articles}

Belden, L. Burr. "Gas Lights, Opera House Bring City Ways During 1880s.” San Bernardino Sun-Telegram, September 28, 1952.

- — - "James Waters Had Big Role In City History." San Bernardino Sun-Telegram, p. 26, February 26, 1956.

Buie, Earl E. “They Tell Me.” San Bernardino Evening Telegram, p. B6, March 28, 1958.

___. “They Tell Me." San Bernardino Sun-Telegram, May 20, 1958.

_—_. “They Tell Me.” San Bernardino Sun-Telegram, May 27, 1958.

-_—. "They Tell Me." San Bernardino Sun-Telegram, n.d.

“Death Takes Mrs. Kiplinger Noted Citizen.” San Bernardino Sun, p. 9, August 18, 1942.

“Graveside Services of Lyman Rich.” San Bernardino Sun, July 7, 1981.

Holliday, Fred. "Trapper James Waters Love the Mountains - and Opera." San Bernardino Sun, p. E4, December 7, 1986.

Metz, Leonard. “Legitimate Theater's Struggle Against Movies Ended in 1927." San Bernardino Sun-Telegram, September 17, 1969.

_-_. "Opera House Met Competition With Advent of Movies in 1904." San Bernardino Sun-Telegram, p. B4, September 16, 1969. 
- - - "The Play's the Thing - Ever Since 1859." San Bernardino Sun-Telegram, September 15, 1969.

Palmer, Chuck. "Hot Times at the Old S.B. Opera House." San Bernardino Sun, p. D4, October 30, 1983.

\section{Periodicals}

The Citrograph (Redlands, California) 1889-1893, 1904-1906.

Madison's Budget, 1905, 1909, 1911, 1913, 1915, 1918, 1921, 1925, 1929.

McNally's Bulletin. 1931.

San Bernardino Daily Sun, 1894, 1899, 1903-1906

Southern California Library Special Collections

A.K. Smiley Public Library, Redlands, California, Heritage Room.

Norman Feldheym Library, San Bernardino, California, California Room.

Riverside Public Library, Riverside, California, Loring Opera House and Theatre Program Collection. 